\title{
Pendidikan Karakter: Konsep dan Aktualisasinya dalam Sistem Pendidikan Islam
}

\author{
Ali Mudlofir \\ Universitas Islam Negeri Sunan Ampel Surabaya \\ Email: mudlofir_ali@yahoo.com
}

\begin{abstract}
Islam highly emphasizes character that becomes the substance of the religion. The character used as the basis of the education system in Islam. Character education is an attempt to make influence the soul of the students to inculcate morals, to shape the human personality and virtuous in accordance with the teachings of Islam. Character education becomes essential for life. Characters are formed by at least covers: religious, honest, tolerant, disciplined, hard-working, creative, independent spirit of nationalism, patriotism, recognize excellence, friendship/communicative, love peace, love reading, environmental care, social care and responsibility. These values are a form of social piety which must be actualized in the education system so that they can ward off the crisis and stem the multidimensional towards the formation of personal morality. The characters must be actualized in the education system so as to form a virtuous man.
\end{abstract}

Keywords : characters, personal morality, social piety.

\begin{abstract}
Abstrak
Islam sangat mengedepankan karakter sehingga menjadi substansi ajaran agamanya. Karakter dijadikan dasar sistem pendidikan dalam Islam. Pendidikan karakter merupakan usaha mempengaruhi jiwa anak didik untuk menanamkan akhlak sehingga terbentuklah manusia yang berkepribadian dan berbudi luhur sesuai dengan ajaran Islam. Pendidikan karakter menjadi penting bagi kehidupan. Karakter yang dibentuk minimal mencakup: religius, jujur,toleran, disiplin, kerja keras, kreatif, mandiri, Semangat kebangsaan, cinta tanah air, menghargai Prestasi, bersahabat/komunikatif, cinta damai, gemar membaca, peduli lingkungan, peduli sosial dan tanggung jawab. Nilai-nilai ini merupakan bentuk kesalehan sosial yang harus diaktualisasikan dalam sistem pendidikan sehingga mampu menepis dan membendung krisis multidimensi menuju terbentuknya pribadi yang berakhlak mulia. Karakter harus diaktualisasikan dalam sistem pendidikan sehingga terbentuk manusia yang berbudi luhur.
\end{abstract}

Kata kunci: Karakter, akhlak mulia, kesalehan sosial. 


\section{A. Pendahuluan}

Diakui dalam berbagai aspek, pendidikan di negeri ini mengalami kemajuan. Sarana dan prasarana sekolah terus mengalami perbaikan. Peningkatan anggaran pendidikan jelas wujud nyata dari tekad pemerintah untuk memajukan dunia pendidikan. Prestasi pelajar dan mahasiswa di berbagai ajang kompetisi nasional maupun internasional juga membanggakan. Generasi penerus itu setidaknya mampu membuat dada para orang tua mengembang bangga karena anak-anak bangsa ini ternyata mampu berkiprah di forum internasional.

Sebagai contoh dari statemen di atas Andy Octavian Latief siswa SMAN 1 Pamekasan berhasil meraih emas di Olimpiade Fisika Internasional ke-37 di Singapura; Firmansyah Kasim, siswa SMP Islam Ațirah Makasar juga sudah dua kali memperoleh juara Olimpiade Fisika Internasional mewakili Indonesia; Irwan Ade Putra,Pelajar SMAN 1 Pekanbaru ini sudah dua kali meraih emas di Apho Kazakhstan dan Ipho Singapura, Olimpiade IPTEK Internasional, International Sustainable World Energy, Engineering \& Environment Project Olympiad,(I-SWEEEP) 2012 diselenggarakan di Houston, Amerika Serikat pada 3-6 Mei 2012.Banyak siswa Indonesia yang menang dalam ajang ini. Mereka memberi bukti nyata bahwa sebetulnya sumber daya manusia kita mampu berjaya bilamana kita bersungguh-sungguh mengupayakannya. Kita bukan bangsa kuli atau inlander bodoh sebagaimana stempel yang ditempelkan kepada kita selama ratusan tahun oleh penjajah. ${ }^{1}$

Di sela-sela prestasi gemilang tersebut di atas, memang harus diakui masih terpampang sisi buram dari mereka. Jumlah kaum muda pengguna narkoba masih mencemaskan. Informasi dari Balai Diklat Badan Narkotika Nasional (BNN), terdapat sekitar 3,6 juta pencandu narkoba di Indonesia yang melibatkan kaum muda. Kekerasan juga banyak mewarnai dunia anak bangsa ini. Kekerasan pada saat Masa Orientasi Siswa (MOS) masih saja terjadi. Oknum kepala sekolah memukul siswa; siswa mengeroyok guru; guru BK mengadu dua siswanya untuk berkelahi di halaman sekolah. Tawuran antar pelajar di jalanan tetap menjadi pemandangan hal yang biasa di media massa.

\footnotetext{
${ }^{1}$ Tempo Interaktif, 27/8/2009.
} 
Dekadensi moral, rendahnya tanggung jawab dan sikap amanah, dipertontonkan secara kasatmata di depan publik. Betapa banyak pejabat publik yang diseret kemeja hijau gara-gara menelan uang rakyat. Pada bulan Maret 2010, lembaga survei yang bermarkas di Hongkong yaitu Political \& Economic Risk Consultancy (PERC) masih menempatkan Indonesia sebagai negara terkorup di Asia Pasifik, mengalahkan posisi Kamboja, Vietnam, dan Filipina.

Semuanya itu terjadi karena pendidikan telah kehilangan jiwanya, telah dilepaskan dari esensinya. "Education worthy of the name is essentially education of character", kata Martin Buber. Tujuan pembelajaran ialah menghasilkan pelajar yang lulus dalam ujian sekolah. Sementara tujuan pendidikan ialah menghasilkan anak didik yang lulus dalam ujian kehidupan. Hasil belajar adalah pengetahuan. Hasil pendidikan adalah Karakter. "The dimensions of character are knowing, loving, and doing the good", kata Thomas Lickona. Saya yakin bahwa para pendidik bangsa ini Dahulu mendirikan sekolah agar anak-anak didik mereka mengetahui yang baik, mencintai yang baik, dan mengamalkan yang baik.

\section{B. Hakikat dan Tujuan Akhir Pendidikan dalam Islam}

Dalam seminar Pendidikan Islam se-Indonesia Tahun 1960 disepakati hakikat pendidikan Islam adalah "bimbingan terhadap pertumbuhan rohani dan jasmani individu sesuai dengan ajaran Islam dengan hikmah mengarahkan, mengajarkan, melatih, mengasuh dan mengawasi berlakunya ajaran Islam pada dirinya". Pengertian tersebut mengandung arti bahwa dalam proses pendidikan Islam terdapat usaha mempengaruhi jiwa anak didik melalui tahapan, setingkat demi setingkat menuju tujuan yang ditetapkan yaitu menanamkan takwa dan akhlak serta menegakkan kebenaran, sehingga terbentuklah manusia yang berkepribadian dan berbudi luhur sesuai dengan ajaran Islam.

Adapun tujuan akhir pendidikan Islam menurut Abdurrahmān al-Nahlawi sebagaimana dikutip oleh Abdul Majid menjelaskan bahwa tujuan pendidikan Islam yaitu memurnikan ketaatan dan peribadatan hanya kepada Allah. Maka karenanya kurikulum pendidikan Islam yang disusun harus menjadi landasan

${ }^{2}$ HM. Arifin, Filsafat Pendidikan Islam, (Jakarta: Bina Aksara, 1987) hlm. 13-14. 
kebangkitan Islam baik dalam aspek intelektual, pengalaman, fisik maupun sosial. ${ }^{3}$ Naquib al-Atțas mengemukakan tujuan akhir pendidikan Islam adalah manusia yang baik. ${ }^{4}$ Sedangkan Atiyyah al-Abrasyi dan Munir Mursy menyetujui pendapat Al-Ghazali bahwa tujuan akhir pendidikan Islam adalah kesempurnaan manusia (al-kamalah al-insaniyah). ${ }^{5}$

Mohammad Fadhil al-Jamali merumuskan tujuan akhir pendidikan Islam dengan empat macam; 1) mengenalkan manusia akan perannya di antara sesama makhluk dan tanggung jawabnya dalam hidup ini; 2) mengenalkan manusia akan interaksi sosial dan tanggung jawabnya dalam tata hidup bermasyarakat; 3) mengenalkan manusia akan alam dan mengetahui hikmah diciptakannya serta mengambil manfaat dari padanya; 4) mengenalkan manusia akan pencipta alam Allah swt. dan tata cara beribadah kepada-Nya. ${ }^{6}$

Muhammad Quthub berpendapat bahwa tujuan akhir pendidikan Islam adalah kesempurnaan manusia secara pribadi atau kelompok yang mampu menjalankan fungsinya sebagai hamba Allah dan khalifah-Nya guna membangun dunia/alam sesuai dengan konsep yang ditetapkan oleh Allah. ${ }^{7}$ Ciri-cirinya mengedepankan prinsip-prinsip berikut:

1. asy-Syumuliyah (universal) antara aspek aqidah, ibadah, akhlak dan muamalah

2. at-Tawazun (keseimbangan) antara aspek pribadi, komunitas dan kebudayaan

3. at-Tabayun (kejelasan) fungsi dan Karakteristik berbagai aspek kejiwaan manusia (qalb, 'aql, dan nafs)

4. at-Tanasub (keterkaitan) antara berbagai aspek tersebut dan tidak saling bertentangan

5. al-Waqi'iy (realistis) dapat dilaksanakan dan tidak berlebihlebihan

${ }^{3}$ Abdul Majid, Pendidikan Agama Islam Berbasis Kompetensi: Konsep dan Implementasi Kurikulum 2004, (Bandung: Rosda Karya, 2004), hlm.78.

4 Syed Mohammad Nuqaib al-Attas, Aims and Objectives of Islamic Education, (Jedah: King Abdul Aziz University, 1979), hlm.1.

${ }^{5}$ Mohammad Munir Mursy, at-Tarbiyah al-Islamiyyah Ușuluha wa Tatawwuruha filbilad al-Arabiyyah, (Kairo: Alam al-Kutub, 1977), hlm. 18.

${ }^{6}$ Lihat Mohammad Fadhil al-Jamali, Filsafat Pendidikan dalam AlQur'an, (terj.) Judial Falasani, (Surabaya: Bina Ilmu, 1986), hlm. 3.

${ }^{7}$ Mohammad Quthub, Manhaj al-Tarbiyah al-Islamiyyah, (Kairo: Dar al-Syuruq, $1400 \mathrm{H})$, hlm. 13. 
6. al-Taqaddumy (dinamis) dapat menerima perubahan sesuai dengan perkembangan situasi dan kondisi masyarakat

7. al-Kamal al-Insaniy (kesempurnaan manusia) yaitu selalu mengedepankan visi dan misi menggapai kesempurnaan pribadi muslim.

Menurut Omar Mohammad al-Taoumy aș-Ṣaibani: bahwa tujuan akhir pendidikan Islam harus mempunyai ciri-ciri sebagai berikut; 1) menonjolkan pendidikan agama dan akhlak; 2) mempertimbangkan pengembangan menyeluruh dari pribadi siswa, jasmani akal dan rohani; 3) mempertimbangkan keseimbangan pribadi dan masyarakat, dunia dan akhirat; 4)Memperhatikan seni, pahat, ukir, tulisan indah, gambar; 5)Memperhatikan perbedaan kebudayaan dan perbedaan individu. ${ }^{8}$

Tujuan akhir Pendidikan Islam menurut rumusan Konferensi Pendidikan Islam sedunia ke 2 tahun 1980 di Islamabad:

"Education should aim at the balanced growth of total personality of man through the training of man's spirit, intellect, the rational self, feeling and bodily sense. Education therefore cater for the growth of man in all its aspect, spiritual, intellectual, imaginative, physical, scientific, and linguistic both individually and collectively and motivate all these aspects toward goodness and attainment of perfection. The ultimate aim of education lies in the realization of complete submission to Allah on the level individual, the community and humanity at large.

\section{Apa Makna Karakter?}

Aristoteles menyebut Pengertian Karakter yang baik adalah kehidupan berperilaku baik dan penuh kebajikan, berperilaku baik terhadap pihak lain Tuhan Yang Maha Esa, manusia, alam semesta dan terhadap diri sendiri. Jonathan Webber dalam Journal of Philosophy menjelaskan bahwa Karakter adalah akumulasi dari

${ }^{8}$ Omar Mohammad al-Thoumy al Syaibani, Filsafat Pendidikan Islam, terj. (Jakarta: Bulan Bintang, 1979), hlm. 489-518.

${ }^{9}$ Lihat HM. Arifin, M. Ed., Ilmu Pendidikan Islam: Suatu Tinjauan Teoritis dan Praktis Berdasar Pendekatan Multidisipliner, (Jakarta: Bina Aksara, 1991), 40. Lihat pula: Second World Conference on Muslim Education, International Seminar on Islamic Concept and Curriculla Recommendation, Islamabad, 15 to 20 March 1980. 
berbagai ciri yang muncul dalam cara berfikir, merasa dan bertindak. ${ }^{10}$ Sikap pemberani atau pengecut seseorang dalam menghadapi bahaya, sikap ketakutan dalam menghadapi orang banyak, merupakan contoh-contoh sederhana tentang Karakter seseorang.

Demikian pula rumusan yang dikemukakan Victor Battistch dari Universitas Missouri St. Louis, dalam salah satu tulisannya berjudul Character Education, Prevention and Positive Youth Development, menegaskan bahwa Karakter adalah konstelasi yang sangat luas antara sikap, tindakan, motivasi dan keterampilan. Karakter mencakup sikap, tindakan, cara berfikir, dan respons terhadap ketidakadilan, interpersonal dan emosional, serta komitmen untuk melakukan sesuatu bagi masyarakat, bangsa dan negaranya. ${ }^{11}$ Sebagaimana Webber, Battistich juga melihat, Karakter selalu dihadapkan pada dilema antara baik buruk, dilakukan atau tidak dilakukan oleh seseorang. Melakukan yang baik berarti berkarakter baik dan ideal, sebaliknya melakukan yang buruk berarti berkarakter buruk.

Sejalan dengan keduanya, Katherine M.H, Blackford dan Arthur Newcomb, dalam tulisannya tentang analyzing character menekankan tentang Karakter seseorang yang senantiasa berlawanan secara diametral antara baik dan buruk. Akan tetapi, Katherine menegaskan bahwa orang-orang yang berkarakter yang bisa diharapkan akan bisa maju dan akan mampu membawa kemajuan adalah mereka yang memiliki ciri-ciri pokok, yakni, kejujuran, bisa dipercaya, setia, bijaksana, penuh kehati-hatian, antusias, berani, tabah, penuh integritas dan bisa diandalkan. ${ }^{12}$ Karakter terdiri dari tiga unjuk perilaku yang saling berkaitan yaitu: 1) tahu arti kebaikan; 2) mau berbuat baik; 3) nyata berperilaku baik. Ketiga substansi dan proses psikologis tersebut bermuara pada kehidupan moral dan kematangan moral individu. Dengan kata lain, Karakter dapat dimaknai sebagai kualitas pribadi yang baik.

${ }^{10}$ Webber, Jonathan, Sarte's Theory of Character, Europe Journal of Philosophy, (UK: Blackwell Publishing House, 2006), hlm. 95.

11 Battistich, Victor, Character Education, Prevention, and Positive Youth Development, (St Louis, USA: University of Missouri, 2002), hlm. 2.

12 Blackford, Katherine M.H., and Arthur Newcomb, Analyzing Character, (Gutenberg: eBook, 2004), hlm. 25. 
Menurut dokumen Desain Induk Pendidikan Karakter terbitan Kementrian Pendidikan Nasional, pendidikan Karakter didefinisikan sebagai pendidikan nilai, pendidikan budi pekerti, pendidikan moral, pendidikan watak. Jenis pendidikan ini ditujukan untuk mengembangkan kemampuan peserta didik untuk mengambil keputusan yang baik, memelihara apa yang baik, dan mewujudkan kebaikan itu dalam kehidupan sehari-hari dengan sepenuh hati. ${ }^{13}$ Yang jelas pendidikan Karakter selayaknya dikembangkan dengan pendekatan terpadu dan menyeluruh.

Efektivitas pendidikan Karakter tidak selalu harus dengan menambah program tersendiri, melainkan bisa melalui transformasi budaya dan kehidupan di lingkungan sekolah. Melalui pendidikan Karakter semua berkomitmen untuk menumbuhkembangkan peserta didik menjadi pribadi utuh yang menginternalisasi kebajikan (tahu dan mau), dan eksternalisasi kebajikan berupa terbiasa mewujudkan kebajikan itu dalam kehidupan sehari-hari.

Hingga saat ini, secara kurikuler telah dilakukan berbagai upaya untuk menjadikan pendidikan lebih bermakna bagi individu, tidak sekadar memberi pengetahuan (kognitif) tetapi juga menyentuh tataran afektif dan psikomotorik melalui mata pelajaran Pendidikan Agama, Pendidikan Kewarganegaraan, Ilmu Pengetahuan Sosial, Bahasa Indonesia, dan Olahraga. Namun harus diakui semua itu belum mampu mewadahi pengembangan Karakter secara dinamis dan adaptif terhadap pesatnya perubahan. Oleh karena itu pendidikan Karakter perlu dirancang-ulang dalam wadah yang lebih komprehensif dan lebih bermakna. Pendidikan Karakter perlu direformulasikan dan direoperasionalkan melalui transformasi budaya dan kehidupan satuan pendidikan.

Secara kejiwaan dan sosial budaya pembentukan Karakter dalam diri seseorang merupakan fungsi dari seluruh potensi individu (kognitif, afektif, dan psikomotorik) dalam konteks interaksi sosiokultural (dalam keluarga, satuan pendidikan, dan masyarakat) dan berlangsung sepanjang hayat. Konfigurasi Karakter dapat dikelompokkan dalam olah hati (spiritual and emotional development), olah pikir (intellectual development), olah raga dan kinestetik (physical and kinestetic development), serta olah rasa dan karsa (affective, attitude and social

${ }^{13}$ Lihat Pusat Kurikulum, Pengembangan Pendidikan Budaya dan Karakter Bangsa, (Jakarta: Badan Litbang Kementerian Pendidikan Nasional, 2010), hlm. 9. 
development). Keempat proses psikososial tersebut secara terpadu saling berkait dan saling melengkapi, yang bermuara pada pembentukan Karakter yang akan menjadi perwujudan dari nilainilai luhur.

Apakah Karakter identik dengan agama? Ada persamaan-persamaan dan juga ada perbedaan antara keduanya. Persamaannya keduanya sama-sama berbicara mengenai baik-buruk, sama-sama berbicara mengenai moral dan kebajikan, namun sumbernya berbeda, agama jelas bersumber dari kitab suci, baik dan buruk bersumber dari kitab suci, sementara Karakter sumbernya akal, budaya dan peradaban manusia.

Diskursus tentang Karakter dan agama ini, patut dicermati dan direnungkan hasil penelitian Scherazade S. Rehman dan Hossein Askari yang disitir oleh Komaruddin Hidayat. Dikatakan bahwa negara dengan mayoritas penduduk Muslim sering tidak Islami. Begitulah kesimpulan artikel Komaruddin Hidayat di harian Kompas. Tulisan Komaruddin ini mengulas sebuah hasil penelitian sosial bertema "How Islamic are Islamic Countries",penelitian itu, dengan metodologi yang juga dijelaskan Komaruddin, membuktikan Selandia Baru adalah negara yang paling Islami di antara 208 negara.

Tulisan itu hendak menyampaikan betapa pentingnya kesalehan sosial dalam peri-kehidupan sehari-hari. Menurut Rehman dan Askari Karakter Islami bukanlah semarak ritual, melainkan seberapa jauh ajaran Islam itu membentuk kesalehan sosial berdasarkan ajaran al-Qur'an dan hadis. Riset itu menyimpulkan, bahwa perilaku sosial, ekonomi, dan politik negara-negara anggota OKI (Organisasi Konferensi Islam) justru berjarak lebih jauh dari ajaran Islam dibandingkan negara-negara non-Islam. Hal itu seolah mengamini pernyataan ulama Muhammad Abduh setelah kunjungannya ke Eropa: "Saya melihat Islam di Eropa, tetapi kalau orang Muslim banyak saya temukan di dunia Arab". 14

Kemendikbud telah mengintrodusir 18 macam inti Karakter dalam desain induk yang akan dikembangkan pada semua kegiatan pendidikan dan pembelajaran serta penciptaan suasana yang kondusif di sekolah, yaitu: ${ }^{15}$

\footnotetext{
${ }^{14}$ Lihat Komaruddin Hidayat dalam Kompas, edisi 5 Nopember 2011.

${ }^{15}$ Pusat Kurikulum, Pengembangan Pendidikan Budaya ..., hlm. 9-10.
} 


\begin{tabular}{|c|c|c|}
\hline No & $\begin{array}{l}\text { Nilai/Inti } \\
\text { Karakter }\end{array}$ & Deskripsi \\
\hline 01 & religius & $\begin{array}{l}\text { sikap dan perilaku yang patuh dalam } \\
\text { melaksanakan ajaran agama yang dianutnya, } \\
\text { toleran terhadap pelaksanaan ibadah agama lain, } \\
\text { dan hidup rukun dengan pemeluk agama lain. }\end{array}$ \\
\hline 02 & jujur & $\begin{array}{l}\text { perilaku yang didasarkan pada upaya menjadikan } \\
\text { dirinya sebagai orang yang selalu dapat dipercaya } \\
\text { dalam perkataan, tindakan, dan pekerjaan. }\end{array}$ \\
\hline 03 & toleran & $\begin{array}{l}\text { sikap dan tindakan yang menghargai perbedaan } \\
\text { agama, suku, etnis, pendapat, sikap, dan tindakan } \\
\text { orang lain yang berbeda dari dirinya. }\end{array}$ \\
\hline 04 & disiplin & $\begin{array}{l}\text { tindakan yang menunjukkan perilaku tertib dan } \\
\text { patuh pada berbagai ketentuan dan peraturan. }\end{array}$ \\
\hline 05 & kerja keras & $\begin{array}{l}\text { perilaku yang menunjukkan upaya sungguh- } \\
\text { sungguh dalam mengatasi berbagai hambatan } \\
\text { belajar dan tugas, serta menyelesaikan tugas } \\
\text { dengan sebaik-baiknya. }\end{array}$ \\
\hline 06 & kreatif & $\begin{array}{l}\text { berpikir dan melakukan sesuatu untuk } \\
\text { menghasilkan cara atau hasil baru dari sesuatu } \\
\text { yang telah dimiliki. }\end{array}$ \\
\hline 07 & mandiri & $\begin{array}{l}\text { sikap dan perilaku yang tidak mudah tergantung } \\
\text { pada orang lain dalam menyelesaikan tugas-tugas. }\end{array}$ \\
\hline 08 & demokratis & $\begin{array}{l}\text { cara berfikir, bersikap, dan bertindak yang menilai } \\
\text { sama hak dan kewajiban dirinya dan orang lain. }\end{array}$ \\
\hline 09 & $\begin{array}{l}\text { rasa ingin } \\
\text { tahu }\end{array}$ & $\begin{array}{l}\text { sikap dan tindakan yang selalu berupaya untuk } \\
\text { mengetahui lebih mendalam dan meluas dari } \\
\text { sesuatu yang dipelajarinya, dilihat, dan didengar. }\end{array}$ \\
\hline 10 & $\begin{array}{l}\text { semangat } \\
\text { kebangsaan }\end{array}$ & $\begin{array}{l}\text { cara berpikir, bertindak, dan berwawasan yang } \\
\text { menempatkan kepentingan bangsa dan negara di } \\
\text { atas kepentingan dari kelompoknya. }\end{array}$ \\
\hline 11 & $\begin{array}{l}\text { cinta tanah } \\
\text { air }\end{array}$ & $\begin{array}{l}\text { cara berfikir, bersikap, dan berbuat yang } \\
\text { menunjukkan kesetiaan, kepedulian, dan } \\
\text { penghargaan yang tinggi terhadap bahasa, } \\
\text { lingkungan fisik, sosial, budaya, ekonomi, dan } \\
\text { politik bangsa. }\end{array}$ \\
\hline 12 & $\begin{array}{l}\text { menghargai } \\
\text { prestasi }\end{array}$ & $\begin{array}{l}\text { sikap dan tindakan yang mendorong dirinya untuk } \\
\text { menghasilkan sesuatu yang berguna bagi } \\
\text { masyarakat, dan mengakui, serta menghormati } \\
\text { keberhasilan orang lain. }\end{array}$ \\
\hline 13 & bersahabat/ & tindakan yang memperlihatkan rasa senang \\
\hline
\end{tabular}




\begin{tabular}{|c|c|c|}
\hline & komunikatif & $\begin{array}{l}\text { berbicara, bergaul, dan bekerja sama dengan } \\
\text { orang lain. }\end{array}$ \\
\hline 14 & cinta damai & $\begin{array}{l}\text { sikap, perkataan, dan tindakan yang menyebabkan } \\
\text { orang lain merasa senang dan aman atas kehadiran } \\
\text { dirinya. }\end{array}$ \\
\hline 15 & $\begin{array}{l}\text { gemar } \\
\text { membaca }\end{array}$ & $\begin{array}{l}\text { kebiasan menyediakan waktu untuk membaca } \\
\text { berbagai bacaan yang memberikan kebajikan bagi } \\
\text { dirinya. }\end{array}$ \\
\hline 16 & $\begin{array}{l}\text { peduli } \\
\text { lingkungan }\end{array}$ & $\begin{array}{l}\text { sikap dan tindakan yang selalu berupaya } \\
\text { mencegah kerusakan pada lingkungan alam } \\
\text { sekitarnya, dan mengembangkan upaya-upaya } \\
\text { untuk memperbaiki kerusakan alam yang sudah } \\
\text { terjadi. }\end{array}$ \\
\hline 17 & $\begin{array}{l}\text { peduli } \\
\text { sosial }\end{array}$ & $\begin{array}{l}\text { sikap dan tindakan yang selalu ingin memberi } \\
\text { bantuan pada orang lain dan masyarakat yang } \\
\text { membutuhkan. }\end{array}$ \\
\hline 18 & $\begin{array}{l}\text { tanggung } \\
\text { jawab }\end{array}$ & $\begin{array}{l}\text { sikap dan perilaku seseorang untuk melaksanakan } \\
\text { tugas dan kewajibannya, yang seharusnya dia } \\
\text { lakukan, terhadap diri sendiri, masyarakat, } \\
\text { lingkungan (alam, sosial dan budaya), negara dan } \\
\text { Tuhan Yang Maha Esa. }\end{array}$ \\
\hline
\end{tabular}

\section{Pola penanaman nilai-nilai karakter dalam Islam}

Sebagai muslim tentu kita tidak bisa melepaskan kajian Karakter dan penanaman nilai Karakter dalam Islam, di mana kita telah yakini bahwa al-Qur'an tidak saja sumber hukum Islam, tetapi lebih dari itu ia adalah kitab Karakter yang Allah swt., tanamkan kepada para nabi dan rasul untuk menjadi teladan bagi umat manusia dalam mendidik anak-anak/generasi penerus mereka.

Dalam perspektif pendidikan Islam, Allah swt., adalah pendidik alam semesta ( $r a b b$ al- 'ālamin) dari kata $r a b b$ itu pulalah kata "tarbiyah" dibentuk, raba-yarbu atau juga rabba-yurabbi yang berarti mengembangkan, memelihara, mendidik, menjaga. Peserta didiknya para nabi dan rasul serta umat manusia, sementara media dan sarana pendidikannya adalah alam semesta, para malaikat memerankan sebagai fasilitator-Nya. Dalam alQur'an banyak ditemukan pola-pola yang dipakai oleh Allah swt., dalam mendidik umat manusia untuk menanamkan dan memperkokoh Karakter mereka. Istilah pola kami maksudkan sebagai strategi atau metode yang dipakai oleh Allah untuk 
menyampaikan pesan sekaligus penanaman Karakter pada hambaNya. Berikut ini di antara contoh bagaimana Islam menanamkan nilai Karakter pada umat Islam melalui ayat al-Qur'an:

1. Penggunaan Strategi Discovery-Inquiry (al-Kasyfu wā alWujdan)

Salah satu strategi penanaman nilai yang dipakai oleh alQur'an adalah Discovery-inquiry (al-wujdany) yang berarti menemukan. Proses strategi ini berawal dari melihat, mengamati, menelaah, mempertanyakan, membandingkan, memetakan, menyimpulkan, kemudian meyakini, dan mengamalkan.

Dalam surat al-An'am ayat $74-79{ }^{16}$ Allah mengisahkan bagaimana Ibrāhim as. menemukan kebenaran (tauhid) setelah mengkaji dan membangun pemahamannya sendiri (insight) sampai akhirnya ia menemukan apa yang di cari. Proses penemuan kebenaran ini bermula Ketika ia melihat fenomena terdekat yaitu patung-patung yang dibuat oleh ayahnya (Azar), yang berlawanan dengan akal sehatnya. Akalnya mengatakan tidak mungkin patung-patung ini memberi manfaat atau madarat kepada manusia karena ia ciptaannya sendiri. Ketidakpercayaan pada patung ini membuatnya berpindah ke benda-benda angkasa yang menurut akalnya lebih "pantas" untuk menjadi Tuhan sebagai sumber kekuatan dan pengendali kehidupan.

${ }^{16}$ Arti ayat-ayat tersebut adalah: "Dan (ingatlah) waktu Ibrahim berkata kepada bapaknya Azar: Pantaskah kamu menjadikan berhala-berhala sebagai tuhan-tuhan?, sesungguhnya aku melihat kamu dan kaummu dalam kesesatan yang nyata (74). Dan demikianlah Kami perlihatkan kepada Ibrahim tanda-tanda keagungan (Kami yang terdapat) di langit dan di bumi dan (Kami memperlihatkannya) agar Ibrahim termasuk orang-orang yang yakin (75). Ketika malam telah menjadi gelap, dia melihat sebuah bintang (lalu) dia berkata: "Inikah Tuhanku", tetapi tatkala bintang itu tenggelam dia berkata: "Saya tidak suka kepada yang tenggelam" (76). Kemudian tatkala dia melihat bulan terbit dia berkata: "Inikah Tuhanku" tetapi setelah bulan itu terbenam dia berkata: "Sesungguhnya jika Tuhanku tidak memberi petunjuk kepadaku pastilah aku termasuk orang-orang yang tersesat" (77). Kemudian tatkala ia melihat matahari terbit dia berkata: "Inilah Tuhanku ini yang paling besar", ketika matahari itu terbenam dia berkata:"Wahai kaumku sesungguhnya aku berlepas diri dari apa yang kau sekutukan"(78). Sesungguhnya aku menghadapkan diriku kepada Tuhan yang menciptakan langit dan bumi dengan cenderung kepada agama yang benar, dan aku bukanlah termasuk orang-orang yang mempersekutukan Tuhan (79). 
Karena itu pertama-tama ia melihat bintang-bintang yang gemerlap di angkasa, Ibrahim tertegun sambil menatapkan pandang sampai akhirnya ia menyimpulkan bahwa bintangbintang itulah Tuhan yang ia cari. Namun suatu saat bintangbintang itu lenyap setelah munculnya bulan purnama yang sangat terang dan indah, Ketika itu sirna pulalah anggapannya pada bintang-bintang tersebut dan tatapan matanya berpindah pada bulan, ia kagumi dan menghayati sampai akhirnya ia menyimpulkan bahwa bulan itulah Tuhannya. Namun tak lama kemudian seiring dengan waktu, bulan itu pun lamalama mengecil dan akhirnya hilang, bersamaan dengan itu Ibrahim semakin ragu pada bulan dan akhirnya ia cabut keyakinannya pada bulan.

Ia kemudian menatapkan pandangannya pada matahari yang menurut akalnya lebih besar dan paling kuat sinarnya di antara benda-benda angkasa lainnya, dengan logika itu ia semakin yakin bahwa matahari itulah Tuhan. Namun tatkala matahari itu selalu menghilang Ketika malam tiba, maka ia juga menyangsikannya dan akhirnya ia batalkan kepercayaannya pada matahari itu.

Pada saat ketakutan dan kebingungan menemukan "alHaqq" seperti itulah akhirnya Allah swt., berkenan memberikan hidayah dan bimbingan-Nya pada Ibrahim lalu ia katakan: "Sesungguhnya aku hadapkan wajahku dengan lurus kepada pencipta langit dan bumi dan bukanlah aku termasuk orang-orang yang menyekutukan-Nya". Petualangan Ibrahim menemukan kebenaran (hakikat) tersebut merupakan gambaran bahwa ada jenis Karakter manusia yang harus dilatih dan dikembangkan dalam proses pendidikan dan pembelajaran di sekolah, keluarga dan masyarakat. Karakter pada kisah Ibrahim dan ayahnya (Azar) tersebut yang paling kuat adalah: a) rasa ingin tahu; b) kreativitas; c) kerja keras; d) ulet.

2. Penanaman Nilai Karakter dengan Keteladanan (Modeling, Uswah)

Dalam surat aṣ-Ṣaffat ayat $102-108^{17}$ Allah mengisahkan bahwa Nabi Ibrahim telah melaksanakan perintah-Nya untuk

${ }^{17}$ Maka tatkala anak itu sampai (pada umur sanggup) berusaha bersama-sama Ibrahim, Ibrahim berkata: "Hai anakku sesungguhnya aku bermimpi bahwa aku menyembelihmu, maka pikirkanlah bagaimana penda- 
menyembelih putranya (Nabi Ismāil), ini menggambarkan proses pembelajaran bagi umat manusia. Dalam ayat-ayat tersebut Allah menyatakan bahwa peristiwa ini sungguh merupakan cobaan/ujian yang nyata, dan cobaan ini juga akan berlaku bagi orang-orang yang datang kemudian, Ibrāhim telah sukses menghadapi ujian ini karena ia telah mampu mengalahkan egoismenya dengan cara melepas sesuatu yang amat dicintai yaitu Ismail.

Dalam peristiwa ini telah terjadi penanaman Karakter keteguhan pribadi Ibrahim. Dalam melaksanakan tugas dan perintah Allah sehingga layak ditiru dan menjadi teladan putranya. Dari sisi Ismāil tertanam Karakter loyal, patuh dan ulet/tabah dalam melaksanakan tugas yang berat dan menyakitkan. Karakter-Karakter tersebut tidak diajarkan tetapi langsung dipraktekkan dan dirasakan. Kisah ini juga menyadarkan kepada umat manusia bahwa keluhuran dan ketinggian derajat kemanusiaan di mata Allah harus dilalui melalui pengorbanan. Ini adalah bentuk pembelajaran yang kontekstual (contextual teaching and learning) dengan mempraktekkan yang dilakukan langsung oleh pendidik dan peserta didik.

3. Penanaman Nilai Karakter dengan Soal-Jawab (QuestionAnswer)

Surat al-Kahfi ayat $65-82^{18}$ berisi kisah yang panjang yang memberikan inspirasi model pembelajaran dialogis antara Nabi Musa dan Nabi Khidir. Keduanya sedang mengadakan perbincangan mengenai hakikat kehidupan.

patmu". Ia menjawab: "Hai bapakku, kerjakanlah apa yang diperintahkan kepadamu, insya Allah kamu akan mendapatiku termasuk orang-orang yang sabar" (102). Tatkala keduanya telah berserah diri dan Ibrahim telah membaringkan anaknya atas pelipisnya (nyatalah kesabaran keduanya) (103). Dan Kami panggillah dia: "Hai Ibrahim (104), Sesungguhnya kamu telah membenarkan mimpi itu sesungguhnya demikianlah Kami memberi balasan kepada orang-orang yang berbuat baik" (105). Sesungguhnya ini benar-benar merupakan ujian yang nyata (106). Dan kami tebus anak itu dengan seekor sembelihan yang besar (107). Dan kami abadikan untuk Ibrahim itu di kalangan orang-orang yang datang kemudian (108).

${ }^{18}$ Artinya:"Lalu mereka bertemu dengan seorang hamba di antara hamba-hamba Kami yang telah Kami berikan kepadanya rahmat dari sisi Kami, dan yang telah Kami ajarkan kepadanya ilmu dari sisi Kami" (65). Musa berkata kepada Khidir: "Bolehkan aku mengikutimu supaya kamu mengajarkan kepadaku ilmu-ilmu yang telah diberikan kepadamu?"(66) 
Kedudukan Musa saat itu sebagai pembelajar (murid) dan Khidir sebagai pengajarnya. Keduanya melakukan pembelajaran dalam kehidupan nyata dengan melakukan perjalanan panjang. Kegiatan yang dilakukan Khidir as juga tampak aneh, membangun rumah reyot yang akan roboh, membunuh anak yang tak berdosa, dan merusak perahu dengan melobangi dinding perahu tersebut. Alhasil, ilmu "hakikat" akhirnya diperoleh oleh Musa as. setelah melalui proses pengamatan dan dialog yang lama dengan Khidir as. Kisah ini sebenarnya merupakan sebuah fragmen pembelajaran dengan mengambil bentuk bertanya dialog (tanya-jawab) dalam membahas ilmu pengetahuan. Nilai Karakter yang menonjol dalam fragmen perjalanan Musa dan Khidir tersebut adalah rasa ingin tahu, kebersamaan, toleran, bertanggung jawab.

4. Penanaman Nilai Karakter Lewat Hukuman dan Hadiah (Reward and Punishment)

Untuk menegakkan norma dan meluruskan perilaku seseorang, al-Qur'an menggunakan hukuman sebagai salah satu metode pembelajaran. Hukuman dipilih sebagai alternatif terakhir Ketika metode-metode lain sudah diterapkan karena para peserta didik melakukan penyelewengan/penyimpangan dari norma yang telah diketahuinya. Hukuman bukan dimaksudkan sebagai cara untuk menyakiti peserta didik namun hukuman bertujuan untuk memberikan kesempatan kepada mereka untuk introspeksi dan mawas diri akan kekeliruan dan kesalahan yang telah dilakukan di masa lalu. Tujuan memberi hukuman adalah agar murid segera melakukan koreksi dan kembali ke jalan yang benar. ${ }^{19}$

Kaum 'Ad, Tsamud dan kaumnya Nabi Lut yang di hukum oleh Allah adalah pelajaran bagi mereka dan bagi orangorang yang datang kemudian untuk tetap berada pada jalan yang benar. Hukuman/peringatan ini berlaku bagi siapa saja termasuk bagi para kekasih Allah. Pada sisi yang lain Allah menampakkan begitu murah dan telah mempersiapkan hadiah bagi hamba-Nya yang saleh dan taat kepada-Nya. Misalnya nilai sedekah dan balasan Allah kepada orang yang bersedekah 1 akan melahirkan 7 tangkai, masing-masing

${ }^{19}$ Mohammad Qutub, Manhaj at-Tarbiyah al-Islamiyyah, (Kairo: Dar al-Shuruq, T.t.) hlm. 233-236. 
tangkai akan melahirkan 100 biji. Nilai Karakter dalam hal ini adalah: disiplin, ulet, teguh dalam pendirian.

5. Penanaman Karakter dengan Prinsip Sinergi/ Keterpaduan (learning to know, learningto do, learning to be, and learning to live together).

Penyatuan dalam penyebutan iman dan amal saleh dalam al-Qur'an diulang sebanyak 52 kali. Ini artinya iman sebagai simbol seperangkat teori pengetahuan yang bersifat kognitif harus selalu diaplikasikan dalam aktivitas konkrit. Wujudnya adalah kompetensi riil yang bersifat psikomotorik. Kompetensi riil tersebut harus bisa dimanifestasikan dalam kehidupan nyata pada masyarakat dalam rangka mewujudkan kehidupan bersama dengan damai bahagia dan sejahtera.

Itulah misi iman dan amal saleh dalam Islam. Tidaklah seseorang dikatakan beriman jika ia tidak mampu mengamalkan (mengaplikasikan) nilai-nilai imannya dalam tindakan amaliah yang nyata. Nabi Muhammad banyak mengingatkan sahabatnya dengan kata "tidaklah beriman" misalnya dalam hadis riwayat Bukhari dan Muslim dari Abu Hurairah, Nabi bersabda: "Demi Allah tidak beriman, demi Allah tidak beriman", sahabat bertanya: "Siapa ya Rasul?" jawab beliau: "Yaitu orang yang tetangganya tidak aman dari gangguan lisan dan tangannya". ${ }^{20}$

\section{E. Penutup}

Untuk menggambarkan bagaimana aktualisasi pendidikan Karakter ini di sekolahkan tampak pada poin-poin berikut:

1. Karakter dalam keseluruhan kecakapan hidup (life skills) anak didik berisi dua kelompok besar kecakapan yaitu kecakapan lunak (soft skills) dan kecakapan keras (hardskills). Karakter masuk pada kelompok softskills. Penanaman Karakter anak didik mengikuti proses seeing (melihat), knowing (mengetahui), loving (mencintai),doing (mengerjakan), habituing (membiasakan), dan buahnya (perilaku). Apa yang dilihat akan dipikirkan; apa yang dipikirkan akan dikatakan; apa yang dikatakan akan dilakukan; apa yang dilakukan akan

20 Al-Imam Abi Zakariya Yahya bin Sharaf Al-Nawawi, Riyadu așSaliḥin (Jedah: Dār al-Qublah li al-Tsaqafah al-Islamiyyah, 1990), hlm. 152. 
diulangi; apa yang diulangi akan dibiasakan, apa yang dibiasakan itulah Karakternya.

2. Proses penanaman Karakter dengan pola akan menghasilkan habituasi/pembiasaan nilai-nilai Karakter di sekolah sehingga anak didik menjadi (berkarakter). Sekolah juga menjalin networking dengan stakeholders misalnya keluarga, tokoh masyarakat, lembaga-lembaga sosial keagamaan, lembagalembaga mitra untuk penanaman nilai Karakter.

3. Pendampingan anak didik dalam melakukan tugas/demonstrasi/praktik kecakapan keras (hard skills) misalnya, praktik melempar cakram, lempar lembing, praktek wudu, tayamum, salat janazah, salat jamak/qasar, salat dluha Karakter terampil, cermat, dan religius.

\section{Kepustakaan}

al-'Ainain, Ali Khalil Abu, Falsafatu at-Tarbiyah al-Islāmiyyah fí al-Qurān al-Karīm, Beirut: Dar al-Fikr al-Araby, 1980.

al-Abrasyi, Mohammad 'Athiyyah, Ruhu al-Tarbiyah wa alTa'lim, Saudi Arabiah: Dar al-Ahya', t.t.

al-Ahwany, Ahmad Fuad, at-Tarbiyah fî al-Islām, Mesir: Dar alMa'arif, t.t.

al-Ațas, Syed Mohammad Nuqaib, Aims and Objectives of Islamic Education, Jedah: King Abdul Aziz University, 1979.

al-Buruswy, Ismail Haqi, Tafsìr Ruhul Bayān, Beirut: Darul Fikr, t.t.

al-Ghalayani, Musthafa, Izatun Nasyi'in, Beirut: Maktabah Ashriyyah, 1949.

al-Hanafi, Abu Su'ud bin Muhammad 'Imady, Tafsir Abì Su'ud, Riyad: Maktabah Riyad, t.t.

al-Jamali, Mohammad Fadhil, Filsafat Pendidikan dalam AlQur'an, (terj.) Judial Falasani, Surabaya: Bina Ilmu, 1986. al-Maraghy, Musthafa, Tafsir al-Maragy, Beirut: Darul Fikr, t.t. al-Qasimy, Mohammad Jamaluddin, Tafsir Mahasin at- Ta'wil, Kairo: Darul Ahya', t.t.

al-Rahlawy, Abdul Rahman, Ușul at-Tarbiyah al-Islāmiyah wa Așalibuha, Beirut: Dar al-Fikr, 1979. 
al-Syaibani, Omar Mohammad al-Thoumy, Filsafat Pendidikan Islam, Jakarta: Bulan Bintang, 1979.

Arifin, HM, Filsafat Pendidikan Islam, Jakarta: Bina Aksara, 1987.

Arifin, HM, Ilmu Pendidikan Islam: Suatu Tinjauan Teoritis dan Praktis Berdasar Pendekatan Multidisipliner, Jakarta: Bina Aksara, 1991.

asy-Syaibani, Omar Mohammad Thoumy, Falsafah Pendidikan Islam, terj., Surabaya: Bina Ilmu, 1986.

Backford, Katherine M.H., and Arthur Newcomb, Analyzing Character, Gutenberg: eBook, 2004.

Battistich, Victor, Character Education, Prevention, and Positive Youth Development,USA: University of Missouri, St Louis, 2002.

Becker, Jaques S.,'The Relationship of Character Education Implementation and Academic Achievement in Elementary School", Journal of Research in Character Education, Fresno: California State University, 2003.

Berkowit, Marvin W., and Melinda C Bier, What Work in Character Education, Character Education Partnership, Washington DC, 2005.

Blackford, Katherine M.H., and Arthur Newcomb, Analyzing Character, Gutenberg: eBook, 2004.

Jalal, Abdul Fattah, Min Ușuli al-Tarbiyah fì al-Islām, Mesir: Dar a-Kutub al-Misriyyah, 1977.

Josephson Institute, Character Counts,USA: Center for Youth Ethic, 2007.

Kebijakan Nasional Pembangunan Karakter Bangsa, Kementrian Koordinator Kesejahteraan Rakyat, 2010.

Majid, Abdul, Pendidikan Agama Islam Berbasis Kompetensi: Konsep dan Implementasi Kurikulum 2004,Bandung: Rosda Karya, 2004.

Mursy, Mohammad Munir, at-Tarbiyah al-Islāmiȳah Usuluha wa Tatawwuruha fi al-Bilād al-Arabiyahah, Kairo: Alam al-Kutub, 1977.

Peraturan Pemerintah No. 55 Tahun 2007, Tentang Pendidikan Agama dan Keagamaan. 
Pusat Kurikulum, Pengembangan Pendidikan Budaya dan Karakter Bangsa, Badan Litbang, Kementrian Pendidikan Nasional, 2010.

Quthub, Mohammad, Manhaj at-Tarbiyah al-Islāmiyaha, Kairo: Dar al-Syuruq, $1400 \mathrm{H}$.

Second World Conference on Muslim Education, International Seminar on Islamic Concept and Curriculla Recommendation, 1980.

State Board of Education, Character Education Informational Handbook and Guide for Support and Implementation for Students Citizen Act of 2011,USA: Character and Civic Education, Department of Public Instruction, North Caroline, 2001.

Undang-undang No. 20 Tahun 2003, Tentang Sistem Pendidikan Nasional.

Webber, Jonathan, Sarte's Theory of Character, Europe Journal of Philosophy, UK: Blackwell Publishing House, 2006.

Winataputra, Udin S, Implementasi Kebijakan Nasional Pembangunan Karakter Bangsa Melalui Pendidikan Karakter, Konsep, Kebijakan, dan Kerangka Programatik, Makalah Seminar di Surabaya, 2010. 


\title{
Islamisasi Pengetahuan dan Model Pengembangannya pada Madrasah
}

\author{
Mukhibat \\ STAIN Ponorogo \\ Email: mukhibat@yahoo.co.id
}

\begin{abstract}
Madrasah in Indonesia have exciting development because of its integration with modernity and political support of the state that aligned with the public schools. However, it is recognized that the model of madrasah education in the country's legislation, led to dualism education system in Indonesia, which has not been resolved until now. The problem is a challenge in realizing the ideal madrasah. Through a historical-philosophical approach, this study examines the redefinition of the Islamization of knowledge by tracing historically the initial idea of Islamization of knowledge in responding to the challenges facing the madrasah. Through critical analysis examines the implications of the redefinition of the Islamization of knowledge and development models at the madrasah. There are at least three models of Islamization of knowledge that can be developed in the development and empowerment of the madrasah, the purification of the model, the model of modernization, and the model of Islamic neo-modernism.
\end{abstract}

Keywords : Islamization of knowledge,madrasah, modernization.

\begin{abstract}
Abstrak
Madrasah di Indonesia mengalami perkembangan menarik karena integrasinya dengan modernitas serta dukungan politik negara sehingga sejajar dengan sekolah umum. Namun demikian, diakui bahwa model pendidikan madrasah di dalam perundang-undangan negara, memunculkan dualisme sistem pendidikan di Indonesia yang belum dapat diselesaikan hingga sekarang. Problem tersebut menjadi tantangan tersendiri dalam mewujudkan madrasah yang ideal. Melalui pendekatan historis-filosofis, penelitian ini mengkaji tentang redefinisi Islamisasi pengetahuan dengan melakukan penelusuran historis terhadap gagasan awal Islamisasi, dalam merespons tantangan yang dihadapi madrasah. Melalui analisis kritis tersebut dikaji implikasi redefinisi Islamisasi pengetahuan dan model pengembangannya pada madrasah. Setidaknya ada tiga model Islamisasi pengetahuan yang dapat dikembangkan dalam pengembangan dan pemberdayaan madrasah, yaitu model purifikasi, model modernisasi, dan model neo-modernisme Islam.
\end{abstract}

Kata kunci: Islamisasi pengetahuan, madrasah, modernisasi 


\section{A. Pendahuluan}

Sebelum memasuki pembahasan topik tersebut di atas sebaiknya kalau dimulai dengan deskripsi jawaban yang sifatnya hipotesis atas pertanyaan: Apakah yang menjadi faktor determinan, sehingga pendidikan Islam mampu survival dalam sejarah yang begitu panjang sampai saat ini? Faktor determinan itu terletak pada kepiawaian pendidikan Islam dalam mengombinasikan dua hal: Pertama, karena secara konsisten berpegang teguh pada tradisi Keislamanya. Kedua, memiliki sikap positif terhadap perubahan yang terjadi di sekitarnya, terutama sejak disahkannya UU Sistem Pendidikan Nasional No 20 Tahun 2003 yang menandakan bahwa eksistensi madrasah sudah cukup kuat beriringan dengan sekolah umum. Kepiawaian tersebut tampak adanya proses dinamika, adaptasi, antisipasi, respons yang tinggi terhadap kemajuan zaman dan madrasah sudah mampu keluar dari sifat eksklusivisme.

Namun dalam perkembangannya, madrasah lebih banyak menikmati pengakuan peran kuantitatif dari masyarakat maupun pemerintah daripada pengakuan kualitatif. Pengakuan peran kuantitatif tersebut menjadikan parameter pendidikan lebih banyak tergantung pada political will pemerintah. Madrasah mau tidak mau harus menerima modernisasi yang berdampak bergesernya paradigma dalam kerangka memenuhi kebutuhan dan tuntutan perubahan. Bahkan tidak jarang banyak yang menyatakan bahwa modernisasi madrasah lebih mudah dipahami sebatas pengalihan konsentrasi siswa dan ketekunan mempelajari agama, menjadi kesungguhan mempelajari mata pelajaran umum. Pembaharuan pada madrasah terkesan potong kompas, yakni ingin langsung memasukkan ilmu-ilmu umum tanpa mempertimbangkan khazanah intelektual muslim. Hal ini memperburuk kebijakan Kemenag melalui Surat Edaran Dirjen Pendis No. Dj 11/PP.00/ED681/2006 tentang pelaksanaan Standar Isi justru menutup peluang MAK sebagai warisan kekhasan madrasah menjadi UPT tersendiri atau satuan pendidikan tingkat menengah. ${ }^{1}$

Diakui bahwa model pendidikan madrasah di dalam perundang-undangan negara, memunculkan dualisme sistem Pendidikan di Indonesia yang belum dapat diselesaikan hingga sekarang. Dualisme ini tidak hanya berkenaan dengan sistem pengajarannya

\footnotetext{
${ }^{1}$ Nunu Ahmad, dkk, Spektrum Baru Pendidikan Madrasah, (Jakarta: Puslitbang Kemenag RI, 2010), hlm. 11.
} 
tetapi juga menjurus pada keilmuannya. Pola pikir yang sempit cenderung memunculkan dikotomi epistemologis-teoritis dan stagnasi konsep pendidikan Islam. Problem tersebut menjadi tantangan tersendiri dalam mewujudkan pendidikan Islam yang ideal. Madrasah tampak berada dalam persimpangan jalan antara mempertahankan tradisi dan mengadopsi perkembangan baru.

Melalui pendekatan historis-filosofis, penelitian ini mengkaji tentang redefinisi Islamisasi pengetahuan dengan melakukan penelusuran historis terhadap gagasan awal Islamisasi pengetahuan dalam merespons tantangan yang dihadapi pendidikan Islam. Lewat analisis kritis tersebut dikaji implikasi redefinisi Islamisasi pengetahuan dan model pengembangannya pada madrasah.

\section{B. Gagasan Islamisasi Pengetahuan}

Diskursus Islamisasi pengetahuan ternyata masih cukup hangat dibicarakan, setelah lahirnya berbagai bentuk madrasah (MA Umum, MA Model, MA Keterampilan, MAK, MA Kejuruan, dan sedang hangat dibicarakan adalah Madrasah terpadu), ${ }^{2}$ apalagi setelah lahirnya berbagai Universitas Islam Negeri (UIN), yang kehadirannya dituntut untuk bisa tampil beda dengan sekolah dan universitas lainnya. Namun kehadirannya itu, sering timbul pertanyaan di masyarakat: apa sebenarnya yang membedakan antara lembaga-lembaga pendidikan di atas dengan lembaga pendidikan lainnya yang telah berkembang jauh sebelumnya? Jika tidak ada distingsi yang jelas untuk apa berbagai bentuk madrasah dan UIN didirikan, jangan-jangan justru malah menambah beban bagi pemerintah dan masyarakat.

Pertanyaan tersebut agaknya bernada sinis, namun hal itu adalah wajar bagi yang belum memahami hakikat atas kehadiran berbagai bentuk madrasah tersebut. Persoalannya adalah: Apakah kehadiran berbagai bentuk madrasah akan mendukung pengembangan Islamisasi Pengetahuan, ataukah justru ada modelmodel lainnya yang hendak dikembangkan, sehingga profilnya akan berbeda dengan yang lain?

${ }^{2}$ Gagasan Madrasah Terpadu muncul setelah melihat Madrasah Model dalam perjalanannya kurang komunikatif dan cenderung individualistik, maka munculah gagasan tentang Madrasah Terpadu, baca, Imran Siregar (ed), Efektifitas Penyelenggaraan Madrasah Terpadu, (Jakarta: Balai Penelitian dan Pengembangan Agama Kemenag RI, 2010), hlm. 3. 
Topik Islamisasi ilmu pengetahuan dan pendidikan dalam Islam sudah diperdebatkan sejak Konferensi Dunia Pertama tentang Pendidikan Islam di Makkah pada 1977. Tetapi sayangnya belum ada usaha serius untuk melacak sejarah gagasan dan mengkaji atau mengevaluasi sejumlah persoalan pokok yang berkenaan dengan topik ini pada tingkat praktis. ${ }^{3}$ Dalam bahasa Arab Islamisasi ilmu disebut sebagai "Islämiyah al-Ma'rifat" dan dalam bahasa Inggris disebut sebagai "Islamization of Knowledge". Dalam Islam, ilmu merupakan perkara yang amat penting, bahkan menuntut ilmu diwajibkan sejak lahir hingga ke liang lahat. Ayat al-Qur'an yang pertama yang diturunkan berkaitan dengan ilmu yaitu surah al-'Alaq ayat 1-5. Menurut ajaran Islam, ilmu tidak bebas nilai-sebagaimana yang dikembangkan ilmuwan Barat akan tetapi sarat nilai, dalam Islam ilmu dipandang universal dan tidak ada pemisahan antara ilmuilmu dalam Islam.

Islamisasi ilmu pengetahuan pada dasarnya adalah suatu respons terhadap krisis masyarakat modern yang disebabkan karena pendidikan Barat yang bertumpu pada suatu pandangan dunia yang lebih bersifat materialistis, sekularistik, relativistis; yang menganggap bahwa pendidikan bukan untuk membuat manusia bijak yakni mengenali dan mengakui posisi masingmasing dalam tertib realitas, akan tapi memandang realitas sebagai sesuatu yang bermakna secara material bagi manusia, dan karena itu hubungan manusia dengan tertib realitas bersifat eksploitatif bukan harmonis. Ini adalah salah satu penyebab penting munculnya krisis dalam modernisasi.

Menurut al-Faruqi Islamisasi pengetahuan adalah menuangkan kembali pengetahuan sebagaimana yang dikehendaki oleh Islam, yaitu dengan memberikan definisi baru, mengatur data, mengevaluasi kembali kesimpulan-kesimpulan dan memproyeksikan kembali tujuan-tujuannya. ${ }^{4}$ Sementara al-Atțas mengatakan bahwa Islamisasi pengetahuan adalah sebagai proses pembebasan atau pemerdekaan. Sebab ia melibatkan pembebasan roh manusia yang mempunyai pengaruh atas jasmaninya dan proses ini menim-

${ }^{3}$ Wan Mohd Nor Wan Daud, Filsafat dan Praktik Pendidikan Islam Syed M. Naquib Al-Attas, (Bandung: Mizan, 2003), hlm. 23.

4 Ismail R. al-Faruqi, Islamisasi Pengetahuan, (Bandung: Balai Pustaka, 1984), hlm. 98. 
bulkan keharmonisan dan kedamaian dalam dirinya, sebagai fitrahnya. $^{5}$

Mencermati konsep tentang Islamisasi pengetahuan di atas, dapat ditarik kesimpulan bahwa gagasan Islamisasi sebenarnya berangkat dari asumsi, bahwa ilmu pengetahuan itu tidak bebas nilai atau netral. Memang, diakui pentingnya transfer ilmu Barat ke Dunia Islam, ilmu itu secara tak terelakkan sesungguhnya mengandung nilai-nilai dan merefleksikan pandangan dunia masyarakat yang menghasilkannya, dalam hal ini masyarakat Barat. Sebelum diajarkan lewat pendidikan, ilmu tersebut harus ditapis terlebih Dahulu agar nilai-nilai yang bertentangan secara diametral dengan pandangan dunia Islam bisa disingkirkan. Gagasan Islamisasi, dengan demikian, merupakan upaya dekonstruksi terhadap ilmu pengetahuan Barat untuk kemudian direkonstruksi ke dalam sistem pengetahuan Islam. ${ }^{6}$

Islamisasi ilmu pengetahuan mencoba mencari akar-akar krisis tersebut. Akar-akar krisis itu di antaranya dapat ditemukan di dalam ilmu pengetahuan, yakni konsepsi atau asumsi tentang realitas yang dualis, sekularis, revolusioneris, dan karena itu pada dasarnya bersifat realitivitas dan nihil. Islamisasi ilmu pengetahuan adalah suatu upaya pembebasan pengetahuan dari asumsi-asumsi atau penafsiran-penafsiran Barat terhadap realitas, dan kemudian menggantikannya dengan pandangan dunia Islam. ${ }^{7}$

Berkaitan dengan keprihatinan pengaruh sains Barat modern, para pembaharu pemikir pendidikan Islam mencoba kembali menggagas konsep Islamisasi sains sekaligus menjadikan Islam sebagai paradigma ilmu pengetahuan. Mereka berupaya membersihkan pemikiran-pemikiran Muslim dari pengaruh negatif kaidahkaidah berfikir ala sains modern, sehingga pemikiran Muslim benar-benar steril dari konsep sekuler. Al-Ațtas mengatakan, bahwa Islamisasi ilmu berarti pembebasan ilmu dari penafsiran-penafsiran yang didasarkan pada ideologi sekuler, dan dari makna-makna serta ungkapan-ungkapan manusia sekuler. ${ }^{8}$

${ }^{5}$ S.M. Naquib Al Attas, The Consept OF Education in Islam, (Kualalumpur: ISTAC), hlm. 43.

${ }^{6}$ Wan Mohd Nor Wan Daud, Filsafat dan Praktik Pendidikan Islam Syed M. Naquib Al-Attas, hlm. 23.

${ }^{7} \mathrm{Al}$ Attas, The Concept of Education ..., hlm. 88.

${ }^{8}$ Mujamil Qomar, Epistemologi Pendidikan Islam dari Metode Rasional hingga Metode Kritik, (Erlangga: Jakarta, 2005), hlm. 116. 
Banyak pemahaman ilmu pengetahuan yang terlanjur tersekulerkan dapat digeser dan diganti dengan pemahaman-pemahaman yang mengacu pada pesan-pesan Islam, manakala "proyek Islamisasi pengetahuan" benar-benar digarap secara serius dan maksimal. Sebagai tindak lanjut dari gagasan-gagasan normatif itu, para pemikir Muslim harus berupaya keras merumuskan kembali Islamisasi pengetahuan secara teoritis dan konseptual yang didasarkan pada gabungan antara argumentasi rasional dan petunjuk-petunjuk wahyu agar konstruksi epistemologi pendidikan Islam sesuai dengan tuntutan zaman.

\section{Islamisasi Pengetahuan dan Implikasinya terhadap Pengembangan Madrasah}

Dari dua gagasan tentang Islamisasi pengetahuan yang dijelaskan di bagian depan, dapat digarisbawahi bahwa Islamisasi pengetahuan lebih melihat pemikiran dan pandangan nonmuslim, terutama pandangan ilmuwan Barat, sebagai ancaman yang sangat dominan dan orang-orang Islam harus berlindung menyelamatkan identitas dan otentisitas ajaran agamanya.

Karena itu, ia cenderung menggali teks dalam rangka mengendalikan perubahan sosial, dan perlu merumuskan ukuranukuran normatif di bidang pengetahuan agar ditemukan corak yang lebih "khas Islam". Islamisasi pengetahuan berarti mengislamkan atau melakukan penyucian terhadap ilmu pengetahuan produk nonmuslim (Barat) yang selama ini dikembangkan dan dijadikan acuan dalam wacana pengembangan sistem pendidikan Islam, agar diperoleh ilmu pengetahuan yang bercorak "khas Islami".

Namun demikian, dengan tanpa berpretensi untuk mengecilkan arti gagasan besar dari kedua tokoh tersebut di atas, agaknya gagasan itu cukup menarik untuk dikritisi ulang dan dikembangkan wawasan dan kawasannya di saat umat Islam telah memasuki era globalisasi dan perubahan sosial yang begitu cepat. Bukankah paradigma tersebut lebih bersifat reaktif dari pada proaktif? Jika sudah ditemukan ciri khasnya yang Islami, kemudian hendak dibawa ke mana? Jangan-jangan ciri khas Islami itu menjadi sesuatu yang standar, baku, absolut, konstan dan rutin, sehingga seolah-olah tidak ada peluang dan gerak yang dinamis. Jika ciri khas Islami itu dipandang sebagai sesuatu yang relatif dan dinamis, maka pertanyaan berikutnya akan segera muncul 
"bukankah umat Islam hanya terjebak dalam pencarian kerangka Islami, dan kurang memiliki kesempatan untuk berobsesi dalam penggalian dan pengembangan IPTEK'? Selama ini ternyata umat Islam masih berada dalam pencarian konsep, kerangka dan paradigma Islamisasi pengetahuan.

Menurut asumsi penulis, sikap tersebut agaknya kurang efektif untuk mengantisipasi era globalisasi, justru umat Islam akan terhambat oleh akselerasi perkembangan dan kemajuan Iptek serta cepatnya arus perubahan sosial. Kiranya cukup menarik untuk dicermati sebuah kritik tajam yang pernah dilontarkan oleh kedua orang orientalis kenamaan, yaitu Ernes Renan (Prancis) dan William Muir (Inggris), yang mengemukakan bahwa "keterbelakangan umat Islam adalah karena peradabannya inferior (berkualitas rendah), dan ini terkait dengan agama mereka yang inferior. ${ }^{9}$

Kritik tersebut merupakan masukan sekaligus tantangan bagi umat Islam untuk tidak mudah terjebak dalam sikap apologis, romantis, dan truth claim dalam menghadapi persoalan Keislaman yang sebenarnya masih berada dalam wilayah ijtihad. Berbagai masukan dan tantangan akan mendorong umat Islam melakukan kebangkitan kembali, melakukan kritik internal, interpretasi kembali terhadap berbagai konsep Islamisasi pengetahuan, sehingga terciptanya keseimbangan antara ketiga dimensi Keislaman (dimensi ideal, interpretasi, dan sejarah). ${ }^{10}$

Islamisasi pengetahuan telah membawa implikasi yang serius terhadap modernisasi Pendidikan Islam termasuk madrasah, yakni pada pola pembaharuan pendidikan yang dijalankan oleh umat Islam. ${ }^{11}$ Berdasarkan dua gagasan tentang Islamisasi pengetahuan di atas, setidaknya ada tiga model Islamisasi pengetahuan yang dapat dikembangkan dalam pembaharuan madrasah yaitu, model purifikasi, model modernisasi, dan model neo-modernis.

Model Purifikasi mengandung arti pembersihan atau penyucian. Dalam arti, ia berusaha menyelenggarakan penyucian ilmu pengetahuan agar sesuai, sejalan dan tidak bertentangan dengan

${ }^{9}$ Mudjia Rahardjo, Quo Vadis Pendidikan Islam, Pembacaan Realitas Pendidikan Islam, Sosial dan Keagamaan, (Malang: UIN Malang Press, 2006), hlm. 223.

${ }^{10}$ Muhaimin, Nuansa Baru Pendidikan Islam, Mengurai Benang Kusut Dunia Pendidikan, (Jakarta: Rajawali Press, 2006), hlm. 42.

11 Zurqoni \& Mukhibat, Menggali Islam Membumikan Pendidikan, Upaya Membuka Wawasan Keislaman \& Pemberdayaan Pendidikan Islam, cet. II (Yogyakarta: Ar-Ruzzmedia, 2013), hlm. 43. 
nilai dan norma Islam. ${ }^{12}$ Model purifikasi berasumsi bahwa dilihat dari dimensi normatif-teologis, doktrin Islam mengajarkan umatnya untuk masuk Islam secara menyeluruh (kaffah) sebagai lawan dari parsial. Dalam al-Qur'an secara apriori menggarisbawahi terwadahinya berbagai aspek kehidupan dalam Islam. ${ }^{13}$ Pandangan ini mempunyai makna bahwa setiap ilmuwan muslim dituntut menjadi aktor beragama yang loyal, concern dan commit dalam menjaga dan memelihara ajaran dan nilai-nilai Islam dalam segala aspek kehidupan. Gagasan al- Faruqi dan al-Attas tentang "Islamisasi Pengetahuan" dapat dikategorikan ke dalam model purifikasi, hal ini dapat dilihat dari empat rencana kerja Islamisasi pengetahuan: 1) penguasaan khazanah ilmu-ilmu Keislaman; 2) penguasaan ilmu-ilmu masa kini; 3) identifikasi kelemahan ilmuilmu umum dalam kaitannya dengan ideal Islam; 4) rekonstruksi ilmu-ilmu umum sehingga menjadi selaras dengan wawasan dan ideal Islam.

Model Modernisasi Islam. Model ini berangkat dari kepedulian akan keterbelakangan umat Islam di dunia sekarang, yang disebabkan oleh sempitnya berpikir, kebodohan, dan eksklusivitas dalam memahami ajaran Islam. Model ini pada dasarnya mengarah pada upaya perbaikan masyarakat muslim dalam cakupan yang luas, terutama menyangkut perubahan pola pikir dan praktek Keislaman. ${ }^{14}$ Jadi makna Islamisasi pengetahuan yang ditawarkan oleh model modernisasi Islam dalam membangun semangat umat Islam untuk selalu modern, maju, progresif, terus menerus melakukan perbaikan dalam berbagai aspek kehidupan agar terhindar dari keterbelakangan dan ketertinggalan di bidang IPTEK.

Adapun keberhasilan pembaharuan pendidikan Islam yang dilakukan oleh umat Islam secara garis besar dapat dikategorisasikan menjadi tiga. ${ }^{15}$ Pertama, pola pembaharuan dengan berorientasi pada pola pendidikan Barat. ${ }^{16}$ Pola ini pada dasarnya

${ }^{12}$ Muhaimin, Nuansa Baru Pendidikan ..., hlm. 61.

${ }^{13}$ Q.S. al-Baqarah/2: 208.

${ }_{14}$ Zurqoni \& Mukhibat, Menggali Islam Membumikan ..., hlm. 44.

15 Zuhairini, dkk. Sejarah Pendidikan Islam, (Jakarta: Bulan Bintang, 1999), hlm. 117.

${ }^{16}$ Umat Islam zaman klasik pernah mencapai kemajuan karena mereka maju dalam bidang ilmu pengetahuan yang dikembangkannya. Dengan demikian mengambil ilmu pengetahuan Barat Modern sebenarnya mengambil kembali ilmu pengetahuan yang pernah dimiliki umat Islam. Lihat Harun 
berangkat dari pandangan bahwa sumber kekuatan dan kesejahteraan hidup yang dicapai Barat adalah sebagai hasil dari perkembangan ilmu pengetahuan dan teknologi modern yang dicapainya. Karenanya untuk mengembalikan kejayaan Islam, sumber kekuatan dan kesejahteraan tersebut harus dikuasai kembali. Penguasaan tersebut dapat dicapai melalui proses pendidikan dengan mengadakan imitasi pola pendidikan yang dikembangkan oleh Barat. Kedua, pola pembaharuan pendidikan Islam yang berorientasi pada sumber Islam murni. Pembaharuan ini pada dasarnya berpijak dari pandangan bahwa sesungguhnya Islam merupakan sumber bagi kemajuan dan perkembangan ilmu pengetahuan modern. Islam sarat dengan ajaran-ajaran yang pada hakikatnya mengandung potensi untuk membawa kemajuan. Sejarah mencatat bahwa di antara sebab-sebab kemunduran umat Islam adalah karena pelaksanaan ajaran Islam tidak sebagaimana mestinya sebagai akibat masuknya bid'ah dalam ajaran Islam. ${ }^{17}$ Ketiga, pola pembaharuan pendidikan yang berorientasi pada nasionalisme. Pola ini berangkat dari pandangan bahwa kemajuan yang dicapai bangsa-bangsa Barat bermula dari rasa nasionalisme yang dimilikinya, yang kemudian menimbulkan kekuatan-kekuatan politik yang berdiri sendiri.

Neo-Modernis berupaya memahami ajaran dan nilai Islam mendasar yang terkandung dalam al-Qur'an dan al-Hadis dengan mengikutsertakan, mempertimbangkan khazanah intelektual muslim klasik serta mencermati kesulitan-kesulitan dan kemudahan-kemudahan yang ditawarkan oleh dunia ilmu pengetahuan dan teknologi modern. Al-Qur'an difungsikan sebagai moral force yang mendorong inisiasi, kreativitas, dan kecerdasan manusia untuk mendayagunakan segenap sumber daya yang tersedia bagi kemaslahatan hidup dan kemajuan budayanya. ${ }^{18}$

Jargon yang dikumandangkan adalah al-muhafazah ala alqadim aṣ-șalih wa al-akhżu bi al-jadid al-aṣlah. Jargon ini meng-

Nasution, Pembaharuan Dalam Islam, (Jakarta: Bulan Bintang, 1994), hlm. 75.

${ }^{17}$ Nasution, Pembaharuan Dalam ..., hlm. 72.

${ }^{18}$ Mahmud Arif, “Aspek Dialogis al-Qur’an dalam Perspektif Pendidikan: Arti Penting Nilai Pedagogis dan pembacaan Produktif” dalam AlTahrir Jurnal Pemikiran Islam, STAIN Ponorogo, Vol 11, No. 2 November 2011 terakreditasi SK Dikti Nomor: 64a/Dikti/Kep/2010, hlm. 291. 
garisbawahi perlunya para ilmuwan muslim untuk mendudukkan pemikiran, konsep, teori-teori dan temuan-temuan ilmu pengetahuan dari para ulama terdahulu ataupun dari ilmuwan nonmuslim. Jargon ini menghendaki kegiatan edukasi pendidikan Islam yang masih terjerembab dalam himpitan romantisme historis untuk segera menyelaraskan dengan tuntutan zaman. ${ }^{19}$

\section{Visi Baru Pembaharuan Madrasah: Keislaman, Keilmuan, Kebinekaan}

Perkembangan madrasah di Indonesia agar berbeda dengan negara-negara lain di Asia Tenggara. Madrasah di Indonesia mengalami perkembangan menarik karena integrasinya dengan modernitas. Dukungan politik negara terhadap pendidikan Islam, kesadaran umat Islam sendiri tentang modernitas, dan transisi menuju modernitas yang berlangsung cenderung masif sehingga menyebabkan madrasah di Indonesia kini muncul sebagai lembaga pendidikan Islam modern. ${ }^{20}$ Madrasah sekarang sudah muncul sebagai lembaga pendidikan Islam modern yang sejajar dengan sekolah umum.

Pasca reposisi madrasah menjadi pendidikan umum menurut UU No. 20 tahun 2003 tentang Sisdiknas, madrasah memegang dua peran sekaligus yakni peran pendidikan agama dan sekaligus pendidikan umum. Di sinilah sesungguhnya kelebihan sekaligus kelemahan madrasah. Jika dua peran ini bisa dimainkan secara baik justru menjadi daya tarik madrasah, namun jika gagal madrasah akan berada dalam tarikan ekstrem antara mempertahankan nilai asasi pesantren mengadopsi perubahan, dan sulit keluar dari lingkaran dikotomi epistemologis-teoritis.

Jalan keluar dari situasi tersebut adalah menuntut adanya implementasi pengembangan model-model Islamisasi pengetahuan dan penegasan visi pendidikan madrasah sehingga madrasah tidak mudah tergoda oleh tarikan ekstrem, tetapi mampu mengelolanya secara responssif dan tuntas. Model-model Islamisasi pengetahuan harus ditempatkan sebagai pemandu bagi madrasah dalam

${ }^{19}$ Majid Irsan al-Kailani, Falsafat at-Tarbiyah al-Islamiyyah, (Mekah: Maktabah Hadi, 1988), hlm. 67.

${ }^{20}$ Arief Subhan, "Persepsi Muslim Indonesia Terhadap Madrasah dan Preferensi Sekolah Mengukur dari Survei”, dalam, Paper for The Secon International Symposium on Empowering Madrasah in The Global Context, (Jakarta: Ministry of Religious Affairs of The Republik Indonesia, 2013), hlm. 4. 
melakukan pengembangan menjadi MA Umum, MAPK, MA Model dan Keterampilan, maupun MA Diniyah yang menjamin konsistensi madrasah dalam konteks perubahan dan dinamika yang terjadi secara terus menerus. Dengan pengembangan tersebut kerangka visi madrasah akan dapat dibangun dengan mempertimbangkan sumber/nilai Islam, Karakter esensial sejarah madrasah, dan rumusan tantangan masa depan. Kerangka visi tersebut sesuai dengan cita-cita umat Islam Indonesia, yakni adanya lembaga pendidikan yang mampu menyiapkan calon ulama yang cendekia dan cendekia yang ulama.

1. Keislaman

Ajaran Islam dengan jelas menunjukkan adanya hubungan organik antara ilmu dan iman. Hubungan organik itu kemudian dibuktikan dalam sejarah Islam klasik Ketika kaum muslimin memiliki jiwa kosmopolit yang sejati. Atas dasar kosmopolitanisme itu umat Islam membangun peradaban dalam arti sebenar-benarnya yang juga berdimensi universal. ${ }^{21}$

Namun demikian, setelah menikmati era kesamaan posisi dengan sekolah umum, madrasah dihadapkan pada masalah yang secara faktual cukup mengganggu kredibilitas madrasah sebagai pusat kegiatan pembelajaran agama Islam. Madrasah dianggap belum mampu membekali peserta didik untuk menjadi pribadi yang Islami. Alokasi waktu yang banyak pada pelajaran agama seharusnya memberikan bangunan yang kuat bagi penanaman nilai-nilai ajaran Islam. Tampaknya mata pelajaran agama Islam belum memberikan fondasi yang kuat bagi keimanan dan ketakwaan pada Allah swt. Madrasah pada kenyataannya tidak saja menjadikan lulusannya serba tanggung antara mata pelajaran agama dan umum. Bahkan justru mengantarkan siswa madrasah meninggalkan orientasi tafaquh fi ad-din ke pola pikir yang serba profan dan materialistik. Pembaharuan pada madrasah terkesan potong kompas, yakni ingin langsung memasukkan ilmu-ilmu umum tanpa mempertimbangkan khazanah intelektual muslim dan bangunan budaya masyarakat muslim yang telah terbentuk berabad-abad.

${ }^{21}$ Nurcholis Madjid, Islam Doktrin dan Peradaban, Sebuah Telaah Kritis tentang Masalah Keimanan, Kemanusiaan dan Kemoderna, (Jakarta: Paradima, 1992), hlm. 24. 
Fakta inilah yang mendorong Munawir Sadzali, mengintrodusir sebagai solusi terhadap apa yang disebutnya "krisis ulama" dengan mendirikan MAPK. Visi MAK adalah penguasaan ilmu pengatahuan khusus tentang ajaran agama Islam (tafaquh fi ad-din). ${ }^{22}$ Namun dengan adanya Surat Edaran Dirjen Pendis No. Dj 11/PP.00/ED681/2006 tentang pelaksanaan Standar Isi justru menutup peluang MAK sebagai warisan kekhasan madrasah. Dengan Surat Edaran tersebut pendidikan agama dibatasi sebatas sebagai mata pelajaran agama, ${ }^{23}$ padahal esensi pendidikan di madrasah adalah penanaman akhlak karimah melalui pembelajaran ilmu-ilmu agama yang mencukupi.

Beberapa kelemahan di atas, menjadikan madrasah dalam posisi yang syarat dengan kritikan bahkan ketidakpercayaan akan fungsi dan urgensinya dalam pembangunan moral dan jati diri bangsa oleh sebagian masyarakat. Kritikan tersebut dialamatkan pada dua hal, yaitu: Pertama, materi atau muatan (content), materi ilmu-ilmu Islam dinilai hanya menekankan pada dimensi teologis (dalam Pengertian yang sempit) dan ritual ajaran Islam. Karena dimensi teologis dan ritual tidak diletakkan dalam kekayaan wacana, maka kajian teologis berhenti pada persoalan Ketuhanan yang bersifat mistisantologis tidak berhubungan dengan realitas kehidupan. Iman sebagai kajian utama pendidikan agama, lebih banyak diorientasikan pada upaya mempertahankan akidah.

Jarang sekali keimanan dikaitkan dengan persoalan yang lebih bersifat kontekstual dalam kehidupan manusia. Kepedulian pada kemiskinan, ketidakadilan, kekerasan, dekadensi moral, dianggap bukan bagian dari proses aktualisasi keimanan. Akibatnya, peserta didik secara verbal dapat memahami ajaran Islam, secara terampil melaksanakannya, tetapi kurang menghayati kedalaman maknanya. Kedua, metodologi. Pelaksanaan pembelajaran ilmu-ilmu Keislaman masih terpaku dengan model konvensional layaknya sebagai pengajian yang monolog dan doktrinatif.

22 Depag RI, Satuan Pendidikan Madrasah Aliyah Keagamaan, (Jakarta: Direktorat Jenderal Pembinaan Kelembagaan Agama Islam, 2001), hlm. 8 .

${ }^{23}$ Ahmad, dkk, Spektrum Baru Pendidikan ..., hlm. 15. 
Dalam keadaan demikian, pendidikan lebih merupakan sebagai perambahan dan pengayaan individu pendidik saja.

Padahal, peserta didik yang telah mempunyai potensi agama (sens of religious) atau keinsafan agama, agama perlu dikembangkan dalam keakraban wacana melalui proses perenungan yang dalam dan proses dialogis yang produktif dan kritis. Hal ini disebabkan karena agama merupakan kekuatan yang mampu meresap jauh ke akar pemikiran dan batin setiap umat manusia. ${ }^{24}$ Dalam konteks ini peserta didik dibiarkan melakukan perambahan batin dan intelektual sehingga kelak menemukan dalam dirinya kedewasaan dalam beragama, baik dalam hal afeksi religiusnya maupun dimensi intelektualnya. ${ }^{25}$ Sebagai akibat adanya kelemahan di atas, maka persoalan yang muncul adalah ilmu-ilmu Keislaman kurang terintegrasi pola pikir yang sempit cenderung membuka jarak antara ilmu-ilmu agama Islam dan ilmu umum.

Menyikapi pudarnya nilai-nilai Keislaman dalam pendidikan madrasah, tidak ada salahnya pemerhati, pengelola, pendamping madrasah mencermati kritikan Nurcholis Madjid terhadap sistem pendidikan tradisional Islam. Nurcholis pernah mensinyalir bahwa lembaga pendidikan Islam termasuk madrasah akan membawa Indonesia pada masa yang akan datang itu seperti sosok"santri yang canggih". ${ }^{26}$ Nurcholis mendambakan penampilan Islam modern yang menyerap secara konstruktif dan positif kehidupan modern, namun semuanya dalam nilai-nilai Keislaman. Dalam bahasa sederhana adanya keselarasan antara IPTEK dan Imtaq.

Perpaduan komponen penunjang IPTEK dan Imtaq diupayakan melalui perpaduan sistem pendidikan tradisional dengan modern. Memasukkan sistem pendidikan "baru" dalam madrasah bukan berarti melepaskan yang "lama" itu

${ }^{24}$ Imam Subchi dkk (ed), Mozaik Pemikiran Islam, (Jakarta: Dikti Kemenag RI, 2011), hlm. 233.

${ }^{25}$ Mukhibat "The Role And Challenges Islamic Education For Reshaping The Nation Character" dalam Conference Proceedings Annual International Conference on Islamic Studies (AICIS) XII, IAIN (Surabaya: Sunan Ampel, 2012), hlm. 2839.

${ }^{26}$ Nurcholis Madjid, Dialog Keterbukaan, Artikulasi Nilai Islam dalam Wacana Sosial Politik Kontemporer, (Jakarta: Paramadina, 1998), hlm. 212. 
mesti dibuang. Pengembangan madrasah harus melihat kembali kitab-kitab lama "klasik" untuk menyikapi agar tidak terjadinya kemiskinan intelektual atau kehilangan jejak riwayat intelektualisme Islam. Kitab kuning jangan dipahami jenis apresiasi doktrinal dan dogmatik, melainkan jenis intelektual dan akademik. Selain itu umat Islam secara wajar mengapresiasikan warisan intelektual dari luar Islam sejalan dengan petunjuk al-Qur'an. Sikap demikian mengindikasikan bahwa umat Islam dalam melakukan pembaharuan madrasah tidak meninggalkan Karakter asli madrasah. Dengan cara ini barangkali merupakan salah satu metode untuk mempertahankan jatidiri madrasah dalam konteks modern.

Berbagai bentuk madrasah yang ada sekarang ini, para pengelola dan stakeholder madrasah harus memikirkan kembali bagaimana menempatkan kembali ilmu-ilmu umum ke dalam daerah pengawasan nilai Islam, karena pada prinsipnya, asal mula semua cabang ilmu pengetahuan adalah berpangkal pada ilmu agama, Seperti Ketika para intelektual muslim mampu mengembangkan dan mengislamkan ilmu pengetahuan modern seperti pada masa Islam klasik. Berbagai upaya pengembangan madrasah harus terlebih Dahulu dengan menangkap pesan dalam al-Qur'an. Modernisasi madrasah tidak boleh hanya mempertimbangkan kondisi, tantangan sosio-historis dan kultural yang dihadapi masyarakat muslim kontemporer, tetapi juga harus Memperhatikan muatanmuatan khazanah intelektual muslim era klasik.

2. Keilmuan

Persoalan mendasar yang terjadi hampir merata di dunia pendidikan Islam kontemporer adalah terpisahnya lembagalembaga pendidikan yang memiliki konsentrasi dan orientasi yang berbeda. Sebagian madrasah menitikberatkan orientasinya pada "ilmu-ilmu modern" dan pada sisi lain ada madrasah yang hanya memfokuskan diri pada "ilmu-ilmu tradisional" yang dikenal dengan dualisme pendidikan.

Islamisasi pengetahuan dengan model modernisme pada prinsipnya menghilangkan dualisme pendidikan tersebut. Kedua orientasi kelembagaan tersebut sama-sama memiliki sisi positif yang patut dikembangkan juga mempunyai kelemahan yang sama sekali harus dibuang dan ditinggalkan. Usaha modernisasi tertuju pada upaya untuk 
mengompromikan kedua orientasi kelembagaan tersebut dengan memadukan sisi baik antara keduanya, yang pada gilirannya akan melahirkan sistem pendidikan Islam yang ideal. Usaha ini dapat disebut dengan sistem pendidikan Indonesia menuju ke arah titik temu atau konvergensi dan usaha ini berawal pada perpaduan unsur-unsur keilmuan.

Upaya menghilangkan dualisme pendidikan tersebut tidak terlepas dari usaha menghilangkan dikotomi keilmuan yang ada sekarang. Sebab mengakarnya paham dikotomi keilmuan amat berpengaruh pada pengembangan madrasah. Pada masa kejayaan Islam, hampir tidak terlihat adanya dikotomi keilmuan. ${ }^{27}$ Karena Islam tidak mengajarkan pemisahan ke dalam ilmu agama dan ilmu umum, seluruh ilmu bersumber dari Allah dan harus dipelajari semuanya.

Sejarah pendidikan Islam telah menunjukkan bahwa keseimbangan antara ilmu agama dan ilmu umum terdapat masa kejayaan dan kegemilangan. Perkembangan ilmu pengetahuan berjalan sangat pesat, seperti ilmu agama, bahasa, sejarah,aljabar, fisika, kedokteran. Tokoh-tokoh seperti al-Farabi, Ibnu Sina, Ikhwan al-Shafa sangat menyadari bahwa kesempurnaan manusia hanya akan terwujud dengan penyerasian antara ilmu umum dan agama, sebagai bagian yang tidak terpisahkan dalam komponen keilmuan dalam Islam.

Madrasah sekarang dan ke depan harus dipahami lebih dari sekadar menjalankan peran yang selama ini dialamatkan madrasah, harus menjadi the centre of excellence baik ilmu agama maupun ilmu umum. Artinya upaya pengembangan madrasah harus menuju ke arah titik temu atau konvergensi yakni perpaduan unsur-unsur keilmuan. Usaha demikian dalam rangka merespons perubahan-perubahan yang begitu cepat baik pada tataran konsep maupun praktek. Madrasah tidak bisa lagi mengisolasikan diri dari perubahan-perubahan paradigma, konsep, visi, dan orientasi baru pengembangan pendidikan nasional.

Sudah saatnya diberikan strategi khusus, bagaimana agar madrasah mampu merespons secara tuntas tuntutan masa depan tanpa mengorbankan identitasnya. Menurut Mujamil

27 M. Athiyah al Abrasyi, Dasar-Dasar Pokok Pendidikan Islam, (Jakarta: Bulan Bintang, 1993), hlm. 167-172. 
Qomar dibutuhkan pengelola madrasah secara kreatif dan inovatif yang berani mengambil kebijakan atau memutuskan hal-hal yang berbeda dengan petunjuk formal dari kalangan atas. ${ }^{28}$ Peluang madrasah untuk tampil sebagai lembaga pendidikan yang menjadi pilihan masyarakat sangat mungkin diwujudkan melalui strategi khusus di atas. Namun tentunya madrasah dituntut mampu menunjukkan berbagai keunggulan, yakni: 1) keunggulan kepribadian Islami, keunggulan ini sangat dibutuhkan oleh masyarakat terutama dalam menghadapi budaya barat yang mengglobal. Kepribadian Islami harus dapat dibuktikan oleh siswa atau alumni madrasah melalui keimanan yang tangguh, ketaatan beribadah, akhlak yang mulia, ahli agama, toleransi, terbuka, demokratis, dan lapang dada; 2) keunggulan intelektual/keilmuan, keunggulan ini sangat dibutuhkan masyarakat terutama untuk menghadapi perkembangan IPTEK. Ini harus mampu diwujudkan oleh siswa atau alumni madrasah seperti Prestasi akademik maupun non akademik; 3) keunggulan keterampilan, keunggulan ini sangat dibutuhkan masyarakat seperti mengoperasikan produk-produk teknologi modern, menembus dunia kerja, mempunyai life skill. Ketiga keunggulan tersebut harus menopang satu sama lain untuk membentuk distingsi alumni madrasah.

Untuk mewujudkan keunggulan-keunggulan tersebut di atas, madrasah harus mampu menerjemahkan model neo modernisme baik dalam tataran kurikulum maupun praktek pendidikannya. Model ini tertuju pada upaya memasukkan kurikulum "umum" ke dalam pendidikan madrasah yang telah memiliki kurikulum tersendiri, sehingga yang akan terjadi kombinasi dua bentuk unsur keilmuan dalam sekala yang utuh. Dengan model ini, akan terjadi semacam enlightening keagamaan pada "ilmu-ilmu umum" kemudian mengintegrasikannya ke dalam hirarki keilmuan Islam. Sehingga disadari bahwa ide ini hanya pada tataran filosofis.

Gagasan di atas, seirama dengan acuan operasional penyusunan kurikulum 2013 yakni semua mata pelajaran dapat menunjang peningkatan iman dan takwa serta akhlak mulia. Hal dapat dilihat dalam rumusan Standar Kelulusan

${ }^{28}$ Mujamil Qomar, Manajemen Pendidikan Islam, (Jakarta: Erlangga, 2007), hlm. 97. 
(SKL) dalam kurikulum 2013 yang lebih dikenal dengan Kompetensi Inti. Kompetensi Inti merupakan terjemahan atau operasionalisasi SKL dalam bentuk kualitas yang harus dimiliki mereka yang telah menyelesaikan pendidikan pada satuan pendidikan tertentu atau jenjang pendidikan tertentu, gambaran mengenai kompetensi utama yang dikelompokkan ke dalam aspek sikap, pengetahuan, dan keterampilan (afektif, kognitif, dan psikomotor) yang harus dipelajari peserta didik untuk suatu jenjang sekolah, kelas dan mata pelajaran. Kompetensi Inti harus menggambarkan kualitas yang seimbang antara pencapaian hard skills dan soft skills. ${ }^{29}$

3. Kebhinekaan

MBS adalah model pengelolaan yang mendasarkan pada kekhasan, Karakteristik, kebolehan, kemampuan, dan kebutuhan sekolah. ${ }^{30}$ Dengan batasan seperti ini, maka MBS menjamin adanya kebhinekaan/keberagaman dalam mengelola sekolah asal tetap dalam koridor kebijakan pendidikan nasional. Tidak ada lagi penekanan pada keseragaman seperti yang selama ini terjadi telah mematikan kreativitas pengelolaan dan pengembangan madrasah sekaligus bertentangan dengan watak populis madrasah.

Pengembangan terhadap madrasah harus didorong munculnya berbagai bentuk, tipe, model, dan pendekatan pendidikan yang bervariasi sesuai dengan kompleksitas masyarakat. Dengan aneka ragam tipe akan memberikan banyak pilihan bagi masyarakat muslim untuk mensekolahkan anak-anaknya sesuai dengan keinginannya. Berbagai program dampingan terhadap madrasah harus memberi ruang tumbuh yang wajar bagi aspirasi umat Islam.

Namun yang perlu diperhatikan dalam program pengembangan ataupun pemberdayaan madrasah, harus diarahkan untuk menciptakan suatu lembaga pendidikan yang mempunyai identitas kultural, yang lebih sejati sebagai konsep pendidikan masyarakat Indonesia baru yang bercirikan keaslian Indonesia. Artinya Ketika madrasah telah dimodemisas tetapi gagal memahami masa lalu, maka yang terjadi adalah

${ }^{29}$ Kementerian Pendidikan dan Kebudayaan, Kurikulum 2013, (Jakarta: Kemdikbud RI, 2013), hlm. 8.

${ }^{30}$ Slamet, Desentralisasi Pendidikan di Indonesia, (Jakarta: Depdiknas, 2008), hlm. 3. 
kemiskinan intelektual. Maka berbagai usaha pemberdayaan dan pengembangan madrasah perlu mempertahankan Karakter asasi pesantren yang ditunjang dengan upaya internalisasi unsur-unsur keilmuan modern dan tujuan-tujuan pragmatis yang ingin dicapai.

\section{E. Penutup}

Sebagai upaya inovasi dalam Sistem Pendidikan Islam, madrasah tidak lepas dari berbagai problema yang dihadapi, antara lain: Pertama, banyak Madrasah Binaan STAIN Ponorogo telah kehilangan akar sejarahnya, sehingga keberadaan madrasah bukan merupakan kelanjutan pesantren. Kedua, munculnya dualisme pemaknaan terhadap madrasah. Madrasah diidentikkan dengan sekolah karena memiliki muatan secara kurikulum yang relatif sama dengan sekolah umum. Di sisi lain, madrasah dianggap sebagai pesantren dengan sistem klasikal. Diakui bahwa model pendidikan madrasah di dalam perundang-undangan negara, memunculkan dualisme sistem pendidikan yang belum dapat diselesaikan sampai sekarang. Dualisme ini tidak hanya berkenaan dengan sistem pengajarannya tetapi juga menjurus pada keilmuannya. Pola pikir yang sempit cenderung membuka jarak antara ilmu-ilmu agama Islam dan ilmu-ilmu umum.

Redefinisi Islamisasi pengetahuan merupakan respons terhadap dikotomi di atas dan sebagai jalan keluar untuk menjadikan madrasah sebagai pendidikan konvergen dengan kurikulum terpadu antara ilmu agama dan ilmu umum. Setidaknya ada tiga model Islamisasi pengetahuan yang dapat dikembangkan dalam pengembangan dan pemberdayaan madrasah, yaitu model purifikasi, model modernisasi, dan model neo-modernisme Islam. Model-model tersebut akan mengarah pada madrasah yang berkarakter Keislaman, keilmuan, dan kebhinekaan. Keislaman, model purifikasi menghendaki bahwa pengembangan madrasah harus melihat kembali kitab-kitab lama "klasik" untuk menyikapi agar tidak terjadinya kemiskinan intelektual atau kehilangan jejak riwayat intelektualisme Islam. Keilmuan, modernisasi madrasah harus menuju ke arah titik temu atau konvergensi yakni perpaduan unsur-unsur keilmuan. Kebhinekaan, pengembangan terhadap madrasah harus didorong munculnya berbagai bentuk, tipe, model, dan pendekatan pendidikan yang bervariasi sesuai dengan kompleksitas masyarakatnya. 


\section{Kepustakaan}

Ahmad, Nunu, dkk, Spektrum Baru Pendidikan Madrasah, Jakarta: Puslitbang Kemenag RI, 2010.

Ahid, Nur, Problematika Madrasah Aliyah di Indonesia, Kediri: STAIN Kediri Press, 2009.

Al Attas, S.M. Naquib, The Consept OF Education In Islam, Kualalumpur: ISTAC, 1991.

Al-Abrasyi, M. Athiyah, Dasar-Dasar Pokok Pendidikan Islam, terj. Jakarta: Bulan Bintang, 1993.

Al-Faruqi, Ismail R, Islamisasi Pengetahuan, Balai Pustaka: Bandung, 1984.

A-Kailani, Majid Irsan, Falsafat al Tarbiyah al Islamiyyah, Mekah, Maktabah Hadi, 1988.

Arif, Mahmud, "Aspek Dialogis al-Qur'an dalam Perspektif Pendidikan: Arti Penting Nilai Pedagogis dan pembacaan Produktif" dalam Al-Tahrir Jurnal Pemikiran Islam, STAIN Ponorogo, 2 November 2011 terakreditasi SK Dikti Nomor: 64a/Dikti/Kep/2010, 2011.

Arifi, Ahmad, Politik Pendidikan Islam; Menelusuri Ideologi dan Aktualisasi Pendidikan Islam Di Tengah Arus Globalisasi, Yogyakarta: Teras, 2009.

Depag RI, Satuan Pendidikan Madrasah Aliyah Keagamaan, Jakarta: Direktorat Jenderal Pembinaan Kelembgaan Agama Islam, 2001.

Kementerian Pendidikan dan Kebudayaan, Kurikulum 2013, Jakarta: Kemdikbud RI, 2013.

Madjid,Nurcholis, Islam Doktrin dan Peradaban, Sebuah Telaah Kritis tentang Masalah Keimanan, Kemanusiaan dan Kemoderna, Jakarta: Paradima, 1992.

----. Dialog Keterbukaan, Artikulasi Nilai Islam dalam Wacana SosialPolitik Kontemporer, Jakarta: Paramadina, 1998.

Muhaimin, Nuansa Baru Pendidikan Islam, Mengurai Benang Kusut Dunia Pendidikan, Jakarta: Rajawali Press, 2006.

Mukhibat, "The Role And Challenges Islamic Education For Reshaping The Nation Character" dalamConference Proceedings Annual International Conference on Islamic Studies (AICIS) XII,IAIN Sunan Ampel, Surabaya, 2012.

Mukhibat, Manajemen Berbasis Sekolah (MBS), Membuka Ruang Kreativitas, Inovasi, dan Pemberdayaan Potensi Sekolah 
Melalui Perluasan Peran Serta Masyarakat, Ponorogo, STAIN Po Press, 2012.

Nasution, Harun, Pembaharuan Dalam Islam, Jakarta: Bulan Bintang, 1994.

Qomar, Mujamil Qomar, Manajemen Pendidikan Islam, Jakarta: Erlangga, 2007.

Qomar, Mujamil, Epistemologi Pendidikan Islam dari Metode Rasional hingga Metode Kritik, Erlangga: Jakarta, 2005.

Rahardjo, Mudjia, Quo Vadis Pendidikan Islam, Pembacaan Realitas Pendidikan Islam, Sosial dan Keagamaan, Malang: UIN Malang Press, 2006.

Setiawan, M Nur Kholis (ed), Model Pengembangan Pendidikan

Tinggi, Pengalaman dari Mesir, Singapura, Jerman dan Australia, Jakarta: Diktis Kemenag RI, 2011.

Siregar, Imran (ed), Efektifitas Penyelenggaraan Madrasah Terpadu, Jakarta: Balai Penelitian dan Pengembangan Agama Kemenag RI, 2010.

Slamet, Desentralisasi Pendidikan di Indonesia, Jakarta: Depdiknas, 2008.

Subchi, Imam, dkk (ed), Mozaik Pemikiran Islam, Jakarta: Dikti Kemenag RI, 2011.

Subhan, Arief, "Persepsi Muslim Indonesia Terhadap Madrasah dan Preferensi Sekolah Mengukur dari Survei", dalam, Paper for The Secon International Symposium on Empowering Madrasah in The Global Context, Jakarta: Ministry of Religious Affairs of The Republik Indonesia, 2013.

Wan Daud,Wan Mohd Nor, Filsafat dan Praktek Pendidikan Islam Syed M. Naquib Al-Attas, Bandung: Mizan, 2003.

Zuhairini, dkk, Sejarah Pendidikan Islam, Jakarta: Bulan Bintang, 1999.

Zurqoni \& Mukhibat, Menggali Islam Membumikan Pendidikan, Upaya Membuka Wawasan Keislaman \& Pemberdayaan Pendidikan Islam, Yogyakarta: Ar-Ruzz media, 2013. 
Vol. 7, Nomor 2, Oktober 2013

\title{
Tantangan Pengembangan Pendidikan Keguruan di Era Global
}

\author{
Fitri Oviyanti \\ IAIN Raden Fatah Palembang \\ Email: fitrioviy@yahoo.com
}

\begin{abstract}
Globalization barrage pass major changes to the world order as a whole. This era is characterized by the process of life worldwide, the advancement of science and technology, especially in the field of communication as well as the transformation and cross-cultural. Changes brought about by globalization are also experienced by the world of education with teachers as practitioners. Challenges faced by teachers in the global era, such as the development of science and technology are so rapid and fundamental; moral crisis that swept the nation and the state, social crisis and a crisis of identity as a nation. All that obviously requires prospective teachers and qualified professionals. Teacher education programs must be able to provide excellent service to the students so that they can establish qualified teacher. Improving the quality of education will foster public confidence that still exist in the future?
\end{abstract}

Keywords: Teacher's education and Globalization.

\begin{abstract}
Abstrak
Globalisasi mewariskan rentetan perubahan besar pada tatanan dunia secara menyeluruh. Era ini ditandai dengan proses kehidupan mendunia, kemajuan ilmu pengetahuan dan teknologi, terutama dalam bidang transformasi dan komunikasi serta terjadinya lintas budaya. Perubahan yang dibawa oleh globalisasi ini juga dialami oleh dunia pendidikan dengan guru sebagai praktisinya. Tantangan yang dihadapi guru di era global, seperti perkembangan ilmu pengetahuan dan teknologi yang begitu cepat dan mendasar; krisis moral yang melanda bangsa dan negara, krisis sosial dan krisis identitas sebagai bangsa. Semua itu jelas menuntut calon guru yang profesional dan bermutu. Program pendidikan guru harus mampu memberikan pelayanan prima kepada mahasiswa sehingga mampu mencetak guru yang berkualitas. Peningkatan mutu pendidikan ini akan menumbuhkan kepercayaan masyarakat sehingga tetap eksis di masa datang.
\end{abstract}

Kata kunci: pendidikan keguruan dan globalisasi 


\section{A. Pendahuluan}

Pendidikan adalah investasi sumber daya manusia (SDM) jangka panjang yang mempunyai nilai strategis bagi kelangsungan peradaban manusia di dunia. Salah satu komponen penting dalam pendidikan adalah guru. Guru dalam konteks pendidikan mempunyai peranan yang besar dan strategis. Hal ini disebabkan karena guru yang berada di barisan terdepan dalam pelaksanaan pendidikan. Guru yang langsung berhadapan dengan peserta didik untuk mentransfer ilmu pengetahuan dan teknologi, sekaligus mendidik dengan nilai-nilai positif melalui bimbingan dan keteladanan. Guru adalah praktisi pendidikan yang sesungguhnya.

Mengingat strategisnya peran guru dalam pendidikan, apalagi di era global ini, maka kebutuhan akan guru yang berkualitas menjadi sebuah keniscayaan demi masa depan bangsa yang gemilang. Kebutuhan akan guru yang berkualitas yang semakin tinggi saat ini harus disikapi secara positif oleh para pengelola pendidikan guru. Respons positif ini harus ditunjukkan dengan senantiasa meningkatkan mutu program pendidikan yang ditawarkannya. Perbaikan mutu pendidikan pada jenjang pendidikan tinggi ini jelas akan membawa dampak positif bagi penciptaan guru yang berkualitas kelak di kemudian hari.

\section{B. Pendidikan Keguruan}

Dalam Pengertian yang sederhana, guru adalah orang yang memberikan ilmu pengetahuan kepada anak didik. Guru dalam pandangan masyarakat adalah orang yang melaksanakan pendidikan di tempat-tempat tertentu, baik lembaga pendidikan formal maupun nonformal. Guru, menurut Zakiah Dradjat adalah pendidik profesional, karenanya secara implisit ia telah merelakan dirinya menerima dan memikul sebagian tanggung jawab pendidikan yang terpikul di pundak orang tua. Guru adalah suatu sebutan jabatan, posisi, dan profesi bagi seseorang yang mengabdikan dirinya dalam bidang pendidikan melalui interaksi edukatif secara terpola, formal, dan sistematis.

Dalam UU Nomor 14 Tahun 2005 tentang Guru dan Dosen, dinyatakan bahwa Guru adalah pendidikan profesional dengan tugas utama mendidik, mengajar, membimbing, mengarahkan, melatih, menilai, dan mengevaluasi peserta didik pada jalur pendidikan formal, pada jenjang pendidikan dasar dan pendidikan menengah. 
Persatuan Guru Republik Indonesia (PGRI) telah merealisasikan Pengertian profesi keguruan untuk pendidikan di Indonesia sebagai berikut:

1. Profesi keguruan adalah suatu bidang pengabdian/dedikasi kepada kepentingan anak didik dalam perkembangannya menuju kesempurnaan manusiawi.

2. Para anggota profesi keguruan, terikat oleh pola sikap dan perilaku guru yang dirumuskan dalam kode etik guru Indonesia.

3. Para anggota profesi keguruan, dituntut untuk menyelesaikan suatu proses pendidikan persiapan jabatan yang relatif panjang.

4. Para anggota profesi keguruan terpanggil untuk senantiasa menyegarkan serta menambah pengetahuan.

5. Para anggota harus memiliki kecakapan/keterampilan teknis yang mampu menyentuh nilai-nilai kemanusiaan yang mendasar.

6. Para anggota profesi keguruan perlu memiliki sikap bahwa jaminan tentang hak-hak profesional harus seimbang dan merupakan imbalan dari profesi profesionalnya.

National Education Association (NEA) mengutarakan ciri-ciri profesi keguruan sebagai berikut:

1. Jabatan yang melibatkan kegiatan intelektual.

2. Jabatan yang menggeluti suatu batang tubuh ilmu yang khusus.

3. Jabatan yang memerlukan persiapan profesional yang lama. Bandingkan dengan pekerjaan yang memerlukan latihan umum belaka.

4. Jabatan yang memerlukan latihan dalam jabatan yang berkesinambungan.

5. Jabatan yang menjanjikan karier hidup dan keanggotaan yang permanen.

6. Jabatan yang menentukan (standar) sendiri.

7. Jabatan yang lebih mementingkan layanan di atas keuntungan pribadi.

8. Jabatan yang mempunyai organisasi profesional yang kuat dan terjalin erat.

\section{Era Global: Pengertian dan Karakteristik}


Era global adalah sebuah perubahan sosial, berupa bertambahnya keterkaitan di antara masyarakat dan elemen-elemen yang terjadi akibat transkulturasi perkembangan teknologi di bidang transportasi dan komunikasi yang memfasilitasi pertukaran budaya dan ekonomi internasional. Globalisasi juga dimaknai dengan gerakan mendunia, yaitu suatu perkembangan pembentukan sistem dan nilai-nilai kehidupan yang bersifat global. Setidaknya terdapat tiga Karakteristik masyarakat di abad 21, yaitu:

1. Masyarakat Teknologi

Masyarakat teknologi yang dimaksud adalah suatu masyarakat yang telah melek teknologi dan menggunakan berbagai aplikasi teknologi, sehingga dapat mengubah cara berpikir, bertindak bahkan mengubah bentuk dan pola hidup manusia yang sama sekali berlainan dengan kehidupan sebelumnya.

Dalam masyarakat seperti itu, peran pendidikan dan guru sangat penting dan strategis, terutama dalam memberikan bimbingan, dorongan, Semangat, fasilitas kepada masyarakat dan peserta didik untuk memperoleh ilmu pengetahuan dan keterampilan menggunakan teknologi. Selain itu, tidak kalah pentingnya adalah peran pendidikan dalam memberikan arahan dan bimbingan agar penguasaan teknologi tidak menjadi bumerang bagi masyarakat, yang disebabkan kurangnya penghayatan terhadap etika.

Pendidikan dan guru dapat menumbuhkan pemahaman etika yang benar, agar kehidupan manusia tidak terancam oleh karena kemajuan teknologi itu sendiri. Manakala pendidikan mengisyaratkan adanya keharusan peserta didik untuk menguasai teknologi, maka tentu tidak kalah pentingnya peran guru itu sendiri untuk lebih dulu menguasai ilmu pengetahuan dan teknologi agar dapat memberikan pengetahuan dan keterampilan teknologi ter-update kepada peserta didiknya.

2. Masyarakat Terbuka

Lahirnya teknologi komunikasi yang demikian maju, membuat dunia menjadi satu seolah tanpa sekat, sehingga komunikasi antar pribadi menjadi makin dekat dan hampir tanpa hambatan, yang pada akhirnya melahirkan masyarakat terbuka. Dalam masyarakat terbuka, antara bangsa satu dengan bangsa lain dapat saling mempengaruhi dalam 
berbagai hal, termasuk mempengaruhi budaya bangsa lain. Hal itu mengancam kehidupan masyarakat lain oleh karena adanya kemungkinan penguasaan atau dominasi oleh mereka yang lebih kuat, yang berprestasi dan yang memiliki modal terhadap masyarakat yang lemah, tidak berdaya dan miskin.

Untuk itu, dalam masyarakat terbuka diperlukan manusia yang mampu mengembangkan kapasitasnya agar menjadi manusia dan bangsa yang kuat, ulet, kreatif, disiplin, dan berprestasi, sehingga tidak menjadi korban dan tertindas oleh zaman yang penuh dengan persaingan. Dalam konteks ini peran pendidikan sangat penting untuk meningkatkan harkat dan martabat suatu masyarakat dan bangsa, agar tidak menjadi bangsa pelayan yang dapat diperintah bangsa lain. Sangat ironis bila bangsa kita yang besar ini tidak mampu bersaing dengan bangsa-bangsa lain, yang hanya mengandalkan kuantitas tanpa kualitas.

3. Masyarakat Madani

Masyarakat madani merupakan wujud dari suatu masyarakat terbuka, di mana setiap individu mempunyai kesempatan yang sama untuk memperoleh ilmu pengetahuan dan keterampilan menggunakan teknologi, berkarya, berprestasi dan memberikan sesuatu sesuai dengan kapasitasnya. Masyarakat madani tumbuh berkembang dalam suatu masyarakat yang saling menghormati, bukan atas dasar asal-usul atau keturunan, tetapi berdasarkan pada kemampuan individual, memiliki toleransi dan tanggungjawab terhadap kehidupan pribadi maupun masyarakatnya, serta menjunjung tinggi rasa kebersamaan untuk mencapai kesejahteraan bersama.

Masyarakat madani tumbuh dan berkembang bukan dengan sendirinya dan bukan tanpa upaya terencana, tetapi masyarakat yang dibangun melalui pendidikan. Kunci terwujudnya masyarakat madani adalah pendidikan, karena melalui pendidikan dapat dibangun sumberdaya yang berkualitas dengan kepribadian yang sesuai dengan budaya serta kesadaran individu hidup berdampingan untuk mencapai tujuan bersama.

\section{Tantangan Guru di Era Global}


Globalisasi telah mengubah cara hidup manusia sebagai individu, sebagai warga masyarakat, dan sebagai warga bangsa. Tidak ada seorang pun yang dapat menghindari arus globalisasi. Setiap individu dihadapkan pada dua pilihan, yakni dia menempatkan dirinya dan berperan sebagai pemain dalam arus perubahan globalisasi, atau dia menjadi korban dan terseret derasnya arus globalisasi.

Seiring dengan Karakteristik era global di atas, maka guru juga harus menghadapi tantangan masyarakat global. Di era global, guru sangat dituntut meningkatkan profesionalitasnya sebagai pengajar dan pendidik. Di samping profesionalitas, guru juga harus menghadapi beberapa kata kunci dunia pendidikan yaitu, kompetisi, transparansi, efisiensi, dan kualitas tinggi. Dari segi sosial, masyarakat global akan menjadi sangat peka dan peduli terhadap masalah-masalah demokrasi, hak asasi manusia, dan isu lingkungan hidup.

Menurut Kunandar, ada beberapa tantangan globalisasi yang harus disikapi guru dengan mengedepankan profesionalismenya, yaitu:

1. Perkembangan ilmu pengetahuan dan teknologi yang begitu cepat dan mendasar. Dengan kondisi ini guru harus bisa menyesuaikan diri secara responsif, arif dan bijaksana. Responsif artinya guru harus bisa menguasai dengan baik produk IPTEK, terutama yang berkaitan dengan dunia pendidikan. Tanpa penguasaan IPTEK yang baik, maka guru menjadi tertinggal dan menjadi korban IPTEK serta menjadi guru yang "isoku iki” (aku cuma bisa ini).

2. Krisis moral yang melanda Indonesia. Akibat pengaruh IPTEK dan globalisasi telah terjadi pergeseran nilai-nilai yang ada dalam kehidupan masyarakat. Melalui pendidikan, guru memiliki tantangan tersendiri untuk menanamkan nilai-nilai moral pada generasi muda.

3. Krisis sosial, seperti kriminalitas, kekerasan, pengangguran, dan kemiskinan yang terjadi dalam masyarakat. Akibat perkembangan industri dan kapitalisme, maka muncul masalahmasalah sosial dalam masyarakat. Mereka yang lemah secara pendidikan, akses dan ekonomi akan menjadi korban. Ini merupakan tantangan guru untuk merespons realitas ini melalui dunia pendidikan. Sebab, sekolah merupakan lembaga pendidikan formal yang sudah mendapat 
kepercayaan dari masyarakat, sehingga harus mampu menghasilkan peserta didik yang siap hidup dalam kondisi dan situasi bagaimanapun.

4. Krisis identitas sebagai bangsa dan Negara Indonesia. Globalisasi juga telah melunturkan identitas kebangsaan (nasionalisme) generasi muda kita. Untuk itu, guru sebagai penjaga nilai-nilai, termasuk nilai nasionalisme harus mampu memberikan kesadaran kepada generasi muda akan pentingnya jiwa nasionalisme dalam kehidupan berbangsa dan bernegara.

Menanggapi persoalan tersebut, dalam peningkatan kualitas pengajaran, guru harus bisa mengembangkan tiga intelegensi dasar siswa. Yaitu, intelektual, emosional dan moral, tiga unsur itu harus ditanamkan pada diri murid sekuat-kuatnya agar terpatri di dalam dirinya. Hal lain yang harus diperhatikan guru adalah dimensi spiritual siswa.

Intelektual siswa harus luas, agar ia bisa menghadapi era global dan tidak ketinggalan zaman apalagi sampai terbawa arus. Selain itu, dimensi emosional dan spiritual pelajar harus terdidik dengan baik, agar bisa melahirkan perilaku yang baik dan siswa bisa bertahan di antara tarik-ulur pengaruh demoralisasi di era global dengan prinsip spiritualnya.

Di samping itu, untuk mempertahankan profesinya, guru juga harus memiliki kualifikasi pendidikan profesi yang memadai, memiliki kompetensi keilmuan sesuai dengan bidang yang ditekuninya, mampu berkomunikasi baik dengan peserta didiknya, mempunyai jiwa kreatif dan produktif, mempunyai etos kerja dan komitmen tinggi terhadap profesinya. Dengan demikian, tantangan guru di era global tidak akan menggusurnya pada posisi yang tidak baik.

Sebagai seorang profesional, guru seharusnya memiliki kapasitas yang memadai untuk melakukan tugas membimbing, membina, dan mengarahkan peserta didik dalam menumbuhkan Semangat keunggulan, motivasi belajar, dan memiliki kepribadian serta budi pekerti luhur yang sesuai dengan budaya bangsa Indonesia. Guru yang profesional merupakan faktor penentu proses pendidikan yang berkualitas.

Guru dalam era teknologi informasi dan komunikasi sekarang ini bukan hanya sekadar mengajar (transfer of knowledge) melainkan harus menjadi manajer belajar. Hal tersebut 
mengandung arti, setiap guru diharapkan mampu menciptakan kondisi belajar yang menantang kreativitas dan aktivitas siswa, memotivasi siswa, menggunakan multimedia, multimetode, dan multisumber agar mencapai tujuan pembelajaran yang diharapkan.

Ada beberapa faktor yang berkaitan dengan beratnya tantangan yang dihadapi oleh profesi keguruan dalam usaha untuk meningkatkan kewibawaannya di mata masyarakat seperti yang dikemukakan oleh Dedi Supriadi sebagai berikut: 1) kekurangjelasan tentang definisi profesi keguruan; 2) desakan kebutuhan masyarakat dan sekolah akan guru berkualitas; 3) sulitnya standar mutu guru dikendalikan dan dijaga; 4) PGRI belum banyak aktif melakukan kegiatan-kegiatan yang secara sistematis dan langsung berkaitan dengan peningkatan profesionalisme guru; 5) perubahan yang terjadi dalam masyarakat melahirkan tuntutan baru terhadap peran (role expectation) yang seharusnya dimainkan oleh guru.

Masyarakat dunia saat ini masuk ke dalam pergaulan era global. Suka atau tidak arus globalisasi adalah arus yang irreversible (tak dapat ditolak). Mengutip Surakhmad, Azyumardi Azra menjelaskan bahwa globalisasi telah menyeret beberapa perubahan (peralihan) paradigma.

Pertama, peralihan dari pendidikan yang mengutamakan nilai kehidupan budaya feodal aristokrasi ke pendidikan yang menggalakkan kehidupan nilai budaya demokrasi. Kedua, peralihan pendidikan yang memihak kepada kepentingan penguasa dan kekuasaan kepada pendidikan yang mengutamakan kepentingan kerakyatan. Ketiga, peralihan pengelolaan pendidikan yang terpusat secara sentralistik kepada pengelolaan pendidikan berbasis kekuatan masyarakat. Keempat, peralihan sikap kependidikan yang mengutamakan keseragaman ke sikap pendidikan yang menghargai keberagaman. Kelima, peralihan pola manajemen pendidikan yang memupuk ketergantungan masyarakat kepada pola manajemen pendidikan yang mengutamakan kemandirian. Keenam, peralihan dari pendidikan yang mengondisi masyarakat takluk kepada gaya pemerintahan penguasa ke pendidikan yang menyadarkan masyarakat tentang pentingnya hukum. Ketujuh, peralihan dari metodologi pendidikan yang mengutamakan pengawetan dan konformisme nilai usang yang disakralkan, kepada metodologi pendidikan yang merintis pengembangan ilmu dan pemanfaatan teknologi. Kedelapan, peralihan dari pandangan kependidikan yang lebih banyak bersifat 
pelaksanaan kewajiban ke pandangan yang mendidik dan menyadarkan warga Negara mengenai HAM. Kesembilan, peralihan dari orientasi pendidikan yang mengutamakan pelestarian dan keseimbangan dari sudut kepentingan politik ke orientasi pendidikan yang mengutamakan perubahan, pertumbuhan dan kemajuan. Kesepuluh, peralihan dari sikap kependidikan yang konformistik, memasung dan punitif, ke sikap pendidikan yang memotivasi, merangsang dan menghargai kreativitas serta inovasi. Kesebelas, peralihan dari pandangan pendidikan yang tertutup ke pandangan pendidikan yang terbuka, fleksibel dan merangsang kerja sama. Kedua belas, peralihan dari program kurikuler yang statis, skolastik, tradisional, ke program kurikuler yang dinamis, riil dan kontekstual.

Kerangka perubahan di atas tentu dengan sendirinya harus membawa perubahan juga pada pola pembelajaran calon-calon guru di perguruan tinggi. Kondisi ini yang menjadi tantangan bagi lembaga pendidikan keguruan, agar dapat menghasilkan lulusan yang tidak hanya sekadar bisa survive, tetapi juga dapat kompetitif menghadapi era global.

\section{E. Tantangan Pengembangan Pendidikan Keguruan di Era Global}

Tantangan globalisasi saat ini makin besar. Persaingan kerja sangat kuat, sehingga lulusan perguruan tinggi yang tidak bermutu tidak akan mendapatkan pekerjaan. Khusus bagi lulusan Fakultas Tarbiyah dan Keguruan serta Fakultas Keguruan dan Ilmu Pendidikan (FKIP), tuntutan banyak yayasan dan sekolah elit terhadap calon guru amat tinggi, seperti guru harus dapat berbahasa Inggris, menguasai informasi, komunikasi dan teknologi (ICT), serta dapat bekerja sama dalam tim. Semua itu jelas menuntut calon guru yang bermutu.

Untuk itu, diperlukan perubahan dalam pendidikan guru, termasuk dalam kurikulumnya. Sayangnya kurikulum yang digunakan khususnya dalam pendidikan Islam kebanyakan belum didasarkan pada asas-asas pembentukan kurikulum yang baik dan bisa menyentuh isu-isu faktual. Kebanyakan kurikulumnya masih kelihatan "usang" dan banyak mengalami problematika Ketika dihadapkan pada kebutuhan globalisasi. Seharusnya kurikulum disesuaikan dengan tuntutan zaman, dan bahan-bahan yang 
diajarkan tidak hanya tentang model pembelajaran, tetapi juga aplikasi dari banyak penemuan modern.

Selain kurikulum,unsur penting dalam pendidikan guru adalah dosen yang membimbing dan mendampingi para mahasiswa calon guru. Apakah dosennya sudah berkualitas tinggi dan berkompetensi dalam bidangnya? Apakah dosen memberikan contoh relasi demokratis dan dialogis dengan mahasiswa selama perjalanan perkuliahan dan dalam banyak kegiatan di Fakultas Tarbiyah dan keguruan atau FKIP? Apakah para mahasiswa Fakultas Tarbiyah dan FKIP sudah dapat merasakan dan mengalami bahwa dosennya memang seorang pendidik yang baik? Semua ini menjadi penting, karena perkuliahan merupakan proses pembelajaran yang panjang dan pada gilirannya nanti membentuk pola pikir dan perilaku mahasiswa calon guru di masa depan.

Dalam kaitan dengan tugas pendidikan, dosen yang bermutu adalah dosen yang melaksanakan tanggung jawab pengajaran, bimbingan, dan latihan keterampilan bagi para mahasiswanya. Sanusi Uwes mengutip Fortunato dan Waddel (1981) merinci tugas pendidikan dan pengajaran menjadi sembilan kegiatan utama, yaitu:

1. Meet all class sections on time

2. Advice and assist students during regularly scheduled office hours

3. Update lecture materials regularly

4. Develop, administer, and score examinations focused on learning experience

5. Provide timely and constructive feedback to student about examinations results

6. Lecture affectively

7. Facilitate class discussions and self-directed learning

8. Cover the course materials as outlined in the syllabus and catalogue

9. Effectively use a variety of media and instructional methods for clarity of presentation and to generate and maintain student interest

Berkaitan dengan tugas pendidikan tersebut dapat dikatakan bahwa penguasaan materi dan keterampilan teknis dalam proses pembelajaran (belajar-mengajar) merupakan dua hal yang mutlak harus dimiliki oleh dosen. Sebab, kedua hal itu memegang peranan 
kunci untuk meningkatkan kualitas pendidikan di perguruan tinggi.

Secara lebih rinci, guna dapat menciptakan pendidikan guru yang berkualitas, berdasarkan beberapa hasil penelitian DarlingHammond. dan Bransford (Ed.), menyatakan bahwa minimal ada tiga elemen penting dalam desain program pendidikan guru yang harus diperbaiki Ketiga elemen tersebut adalah sebagai berikut:

1. Konten pendidikan guru, berkenaan dengan materi yang harus diberikan kepada para mahasiswa, bagaimana cara memberikannya, bagaimana memadukan berbagai materi tersebut sehingga bermakna, termasuk juga bagaimana perluasannya agar mahasiswa memiliki peta kognitif yang akan membantu mereka melihat hubungan antara domain pengetahuan keguruan dengan penggunaannya secara praktis di lapangan untuk mendorong para siswanya belajar.

2. Proses pembelajaran, berkenaan dengan penyusunan kurikulum yang sejalan dengan kesiapan mahasiswa dan mendasar pada materi serta proses pembelajaran praktis yang mampu menimbulkan pemahaman mahasiswa melalui kreativitas aktifnya dalam kelas.

3. Konteks pembelajaran, yang berkenaan dengan penciptaan proses pembelajaran kontekstual guna mengembangkan keahlian praktis mahasiswa. Konteks pembelajaran ini harus diterapkan baik dalam domain-domain materi ajar melalui pembelajaran di komunitas profesional (sekolah).

Terkait dengan pendapat di atas, Lang dan Evans secara lebih gamblang menyatakan bahwa penciptaan program pendidikan bermutu dapat didasarkan atas esensi-esensi program pendidikan guru sebagai berikut:

1. Keberartian teori disertai pengalaman praktisnya.

2. kerjasama antara perguruan tinggi dengan komunitas pendidikan lainnya.

3. Teori dan praktis dalam keterampilan generik dan refleksi serta diskusi tentang efektivitas keterampilan tersebut.

4. Memberikan penekanan proses pada bagaimana caranya mahasiswa belajar untuk meningkatkan kreativitas dan kemampuan berpikir kritis.

5. Kemampuan untuk mengorganisasikan pembelajaran.

6. Penerapan pendekatan konstruktivisme dalam pembelajaran.

7. Penerapan alternatif asesmen dan teori motivasi. 
8. Membangun profesionalisme berbasis penelitian.

Mencermati uraian di atas, maka dengan demikian, perlu dilakukan redesain pendidikan keguruan agar dapat menjawab tantangan globalisasi, yaitu:

1. Isi Kurikulum Pendidikan Keguruan

Kurikulum pada lembaga pendidikan keguruan di era global ini harus lebih dikuatkan "content" keilmuannya. Misalnya, ilmu-ilmu pendidikan, pedagogi, metodologi pendidikan, harus benar-benar dimatangkan. Setelah konten keilmuan kuat secara teori, maka selanjutnya mahasiswa keguruan harus dilatih untuk mempraktekkannya di lapangan. Porsi antara konten keilmuan dengan praktik sebaiknya berkisar $60 \%$ teori, $40 \%$ praktek. Hal ini dilakukan agar program pendidikan guru mampu mendidik calon guru dalam asumsi dasar belajar tentang konsep praktis dalam praktiknya.

Jadi, program pendidikan guru yang berkualitas bukanlah program pendidikan guru yang hanya memberikan pengetahuan berbagai model dan strategi pembelajaran kepada para mahasiswa melainkan yang mampu menerapkan berbagai model dan strategi tersebut kepada mahasiswa, sehingga mahasiswa memperoleh konsep teori dan gambaran aplikasinya sekaligus. Mahasiswa Fakultas Tarbiyah dan Keguruan, misalnya seharusnya melakukan Praktek Pengalaman Lapangan kependidikan (PPLK II) minimal satu semester (6 bulan) di sekolah, agar mereka benar-benar dapat mengalami secara nyata pernak-pernik dunia pendidikan yang kompleks. Melalui pengalaman nyata ini, diharapkan keluhan atas ketidaktahuan guru atas berbagai model dan strategi pembelajaran serta ketidakmampuan guru menerapkan berbagai model dan strategi tersebut akan mampu diminimalisasi. Selain itu dengan menerapkan berbagai model dan strategi tersebut langsung kepada para mahasiswa, kreativitas mahasiswa akan meningkat dan para calon guru ini akan memahami benar bahwa menjadi guru pada dasarnya adalah usaha untuk senantiasa menjadi pembelajar yang profesional.

Pertanyaan kedua tentang apa yang dapat dilakukan guru akan mendorong pelaksanaan program pendidikan guru mengarah pada penggalian potensi dan kebutuhan para mahasiswa disesuaikan dengan kondisi nyata kinerja guru di 
lapangan. Dengan demikian, program pendidikan guru akan senantiasa menitikberatkan pada penciptaan hard skills dan soft skills yang harus dimiliki guru. Hal ini berarti bahwa program pendidikan guru harus mampu memberikan keterampilan profesional kepada para lulusan sekaligus menciptakan lulusan yang memiliki kemampuan berpikir tinggi yang akan sangat bermanfaat untuk mengembangkan profesionalisme Ketika mereka sudah menjadi guru kelak. Oleh karenanya, pelaksanaan proses pendidikan pada program pendidikan guru haruslah diarahkan pada upaya mengenalkan dan memainkan mahasiswa sebagai guru selama ia menempuh studinya.

2. Proses Kuliah Berbasis Kontekstual,Konstruktivisme, dan Aktif

Dari segi proses, pembelajaran di lembaga pendidikan keguruan harus menerapkan pendekatan kontekstual, dan konstruktivisme. Hal ini penting, karena pendekatanpendekatan ini akan membentuk Karakter "pembelajar" pada diri mahasiswa calon guru. Sebab, guru di era global bukan hanya mengajar, tetapi juga membentuk Karakter pembelajar pada diri peserta didiknya.

Selain itu, metode-metode pembelajaran aktif juga perlu diterapkan oleh para dosen yang mengajar mahasiswa calon guru. Metode-metode ini dapat merangsang motivasi dan kreativitas mahasiswa, sehingga kelak mereka dapat menjadi guru yang kreatif. Kelengkapan sarana dan prasarana yang sesuai dengan tuntutan globalisasi, pada gilirannya menjadi komponen yang cukup penting untuk diperhatikan dalam lembaga pendidikan keguruan. Guru di era global harus menguasai ICT, sehingga calon-calon guru harus terbiasa dengan proses perkuliahan berbasis ICT.

3. Pendidikan Keguruan Berbasis Penelitian

Pengembangan pendidikan guru yang profesional juga dapat dibentuk melalui peningkatan proses pembelajaran berbasis penelitian. Hal ini berarti bahwa sejak awal para mahasiswa seharusnya sudah diajak untuk melakukan penelitian sederhana pada setiap mata kuliah. Melalui gaya pembelajaran seperti ini, para calon guru diharapkan mampu menemukan esensi guru yang sebenarnya sekaligus 
membangun kompetensi mereka untuk terampil melaksanakan penelitian Ketika kelak mereka menjadi guru.

Selain itu, pembelajaran berbasis penelitian juga dapat ditafsirkan bahwa proses pembelajaran yang dilakukan di perguruan tinggi senantiasa didasarkan atas hasil-hasil penelitian terkini sejalan dengan scientific vision dan market signal sehingga lulusan akan memiliki sejumlah keterampilan yang benar-benar dibutuhkan di lapangan.

4. Pembelajaran berbasis ICT

Kendati bukan segala-galanya, tetapi walau bagaimanapun sarana dan prasarana yang lengkap dan berbasis ICT akan sangat membantu mahasiswa-mahasiswa calon guru untuk belajar lebih baik dan lebih cepat. Era global adalah era yang sangat akrab dengan ICT, sehingga calon-calon guru juga harus dibekali dan dibiasakan dengan proses pembelajaran berbasi ICT, agar tidak menjadi guru yang "isoku iki".

5. Pengelolaan lembaga pendidikan keguruan berbasis mutu

Pada akhirnya, penciptaan program pendidikan yang berkualitas akan sangat bergantung pada kesadaran mutu para pengelolanya. Sehubungan dengan hal ini, para pengelola lembaga pendidikan tinggi keguruan sudah seyogianya menjalankan proses pendidikan berdasarkan penjaminan mutu yang jelas. Dari sisi rekrutmen calon mahasiswa, seharusnya penerimaan mahasiswa Fakultas Tarbiyah dan Keguruan serta FKIP melalui tahap seleksi yang cukup ketat dan kompetitif.

Tes bakat minat, bahkan ukuran fisik yang ideal (baca tinggi badan), sepertinya sudah harus dilakukan mengingat di era global profesi guru akan semakin signifikan perannya. Jangan sampai ada lulusan Fakultas Tarbiyah atau FKIP yang "terpaksa" menjadi guru. Guru adalah profesi mulia yang membutuhkan loyalitas serta totalitas pengabdian, sehingga tidak mungkin dapat dilakukan dengan setengah hati.

Selain itu, para pengelola program pendidikan guru juga diharuskan mampu memberikan pelayanan prima kepada mahasiswa sehingga seluruh program yang dilaksanakannya mampu mengantarkan mahasiswa menjadi SDM yang berkualitas. Dampak peningkatan mutu ini akan bermuara pula pada kepercayaan masyarakat terhadap lembaga pendidikan keguruan tersebut, sehingga keberlangsungan 
program pendidikan guru tersebut akan terjamin pada masa yang akan datang.

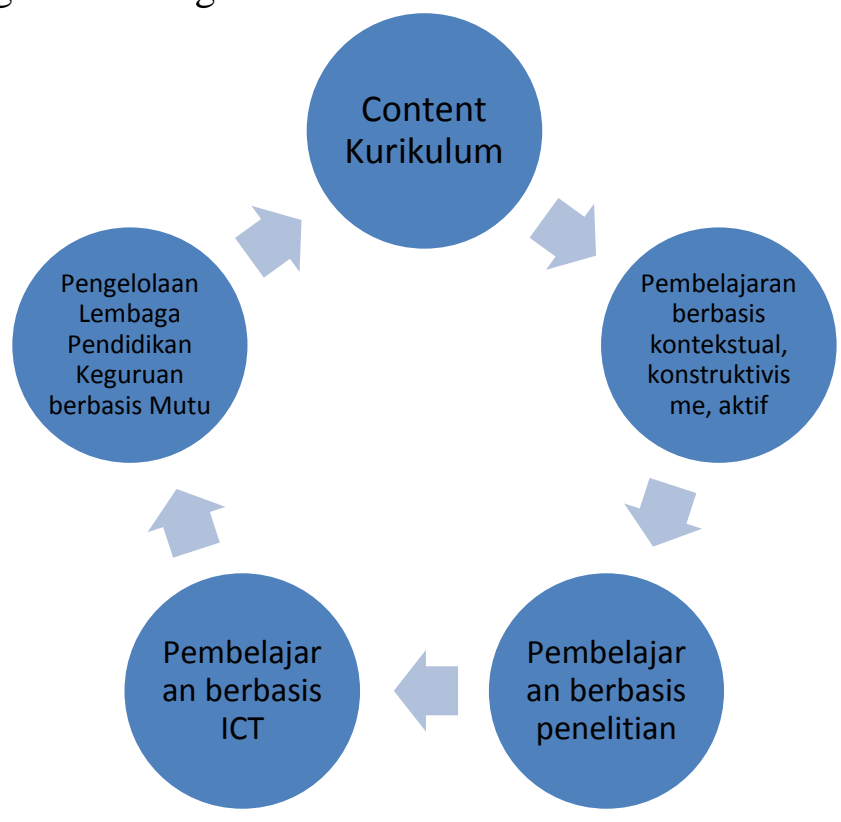

\section{REDESAIN PROGRAM PENDIDIKAN KEGURUAN}

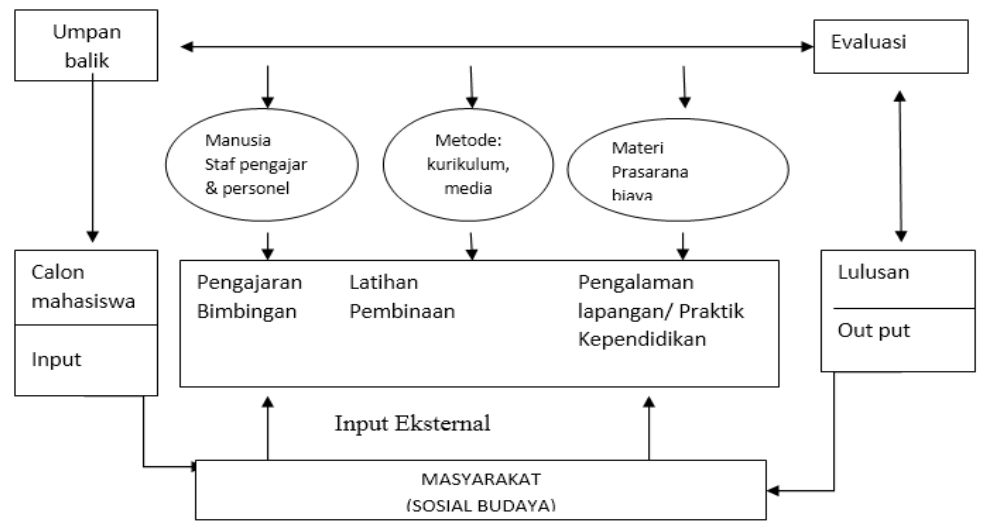

\section{F. Penutup}

Era global memberikan perubahan besar pada tatanan dunia secara menyeluruh dan perubahan itu dihadapi bersama sebagai suatu perubahan yang wajar. Sebab mau tidak mau, siap tidak siap perubahan itu akan terjadi. Era ini ditandai dengan proses 
kehidupan mendunia, kemajuan ilmu pengetahuan dan teknologi, terutama dalam bidang transformasi dan komunikasi serta terjadinya lintas budaya. Era "kesejagadan", begitu istilah Azyumardi Azra untuk merujuk istilah era global.

Perubahan yang dibawa oleh globalisasi ini, mau atau tidak mau juga dialami oleh dunia pendidikan dengan guru sebagai praktisinya. Ada beberapa tantangan yang dihadapi guru di era global dengan harus mengedepankan profesionalismenya, seperti perkembangan ilmu pengetahuan dan teknologi yang begitu cepat dan mendasar; krisis moral yang melanda Indonesia, krisis sosial dan krisis identitas sebagai Bangsa dan Negara Indonesia. Semua itu jelas menuntut calon guru dan pendidik yang bermutu.

\section{Kepustakaan}

Azra, Azyumardi, Pendidikan Islam: Tradisi dan Modernisasi di Tengah Milenium III, Jakarta: Kencana, 2012.

Djamarah, Saiful Bahri, Guru dan Anak Didik dalam Interaksi Edukatif, Jakarta: Rineka Cipta, 2000.

Daradjat, Zakiah, Ilmu Pendidikan Islam, Jakarta: Bumi Aksara, 1991.

Hamalik, Oemar, Pendidikan Guru Berdasarkan Pendekatan Kompetensi, Jakarta: Bumi Aksara, 2009.

Isjoni, Pendidikan sebagai Investasi Masa Depan, Jakarta: Obor, 2006.

Kunandar, Guru Profesional: Implementasi Kurikulum Tingkat Satuan Pendidikan (KTSP) dan Sukses dalam Sertifikasi Guru, Jakarta: Rajawalai Pers, 2007.

Ma'arif, Syamsul, Revitalisasi Pendidikan Islam, Yogyakarta: Graha Ilmu, 2007.

Muhaimin, Pemikiran dan Aktualisasi Pengembangan Pendidikan Islam, Jakarta: Rajawali Pers, 2011.

Rusman, Model-Model Pembelajaran: Mengembangkan Profesionalisme Guru, Jakarta: Rajawali Pers, 2010.

Soetjipto dan Raflis Kosasi, Profesi Keguruan, Jakarta: Rineka Cipta, 2007. 


\title{
Integrasi Pembelajaran Active Learning dan Internet-Based Learning dalam Meningkatkan Keaktifan dan Kreativitas Belajar
}

\author{
Mukhlison Effendi \\ STAIN Ponorogo \\ Email: ef.muikhlison@yahoo.co.id
}

\begin{abstract}
The learning process in higher education can use constructivist learning strategies for activeness and creativity of students. This study aimed to describe the integration of active learning and internet-based learning and to explain the factors supporting and inhibiting. From the observation data, interviews and documentation of the 31 students of the Department of Teacher Education for Islamic Primary Education (PGMI) and the lecturer of STAIN Ponorogo can be seen that the integration of active learning and Internetbased learning can enhance the activeness and creativity of student learning in the course. Factors supporting this result are the application of learning strategies, giving clear guidance, student learning motivation high and the availability of learning facilities and infrastructure. The factors that inhibit is the limited time, the dominance of smart students and unpreparedness of students receiving new material.
\end{abstract}

Keywords: active learning, internet-based learning, activeness, creativity.

\begin{abstract}
Abstrak
Proses pembelajaran di perguruan tinggi dapat menggunakan strategi pembelajaran konstruktivistik untuk keaktifan dan kreativitas mahasiswa. Penelitian ini ditujukan untuk mendeskripsikan integrasi active learning daninternet-based learning untuk menjelaskan faktor pendukung dan penghambatnya. Dari data observasi, interview dan dokumentasi terhadap 31 mahasiswa Program Studi Pendidikan Guru Madrasah Ibtidaiyah (PGMI) dan dosen STAIN Ponorogo dapat diketahui bahwa integrasi active learning dan internet-based learning dapat meningkatkan keaktifan dan kreativitas belajar mahasiswa di program studi tersebut. Faktor yang mendukung hasil ini adalah penerapan strategi pembelajaran, pemberian pengarahan yang jelas, motivasi belajar mahasiswa yang tinggi dan tersedianya sarana dan prasarana pembelajaran. Adapun faktor yang menghambat adalah keterbatasan waktu, dominasi mahasiswa pintar dan ketidaksiapan mahasiswa menerima materi baru.
\end{abstract}

Kata kunci: active learning, internet-based learning, keaktifan, kreativitas. 


\section{A. Pendahuluan}

Pembelajaran merupakan proses interaksi baik antara pendidik dengan peserta didik,peserta didik dengan peserta didik,maupun peserta didik dengan lingkungannya yang dapat merangsang peserta didik untuk belajar. Melalui proses interaksi, kemampuan peserta didik akan berkembang baik mental maupun intelektualnya.

Model pembelajaran di pendidikan tinggi masih cenderung dominan menggunakan strategi pembelajaran exposition atau ekspositori. Dalam strategi pembelajaran exposition,bahan pelajaran disajikan kepada peserta didik dalam bentuk jadi dan peserta didik dituntut untuk menguasai bahan tersebut. Akibatnya, mahasiswa menjadi cukup pasif tidak ada inisiatif untuk berpartisipasi dalam proses perkuliahan karena kurang adanya kondisi yang memungkinkan mahasiswa membangun sendiri pengetahuannya. Keberanian mahasiswa didik untuk bertanya,mengajukanpendapat,berdiskusisepertinyatelah"terpasun geoleh tradisi dosen yang mendominasi perkuliahan.

Keaktifan peserta didik dalam proses pembelajaran akan menyebabkan interaksi yang tinggi antara pendidik dengan peserta didik atau dengan peserta didik itu sendiri. Hal ini akan mengakibatkan suasana kelas menjadi segar dan kondusif, di mana masing-masing peserta didik dapat melibatkan kemampuannya semaksimal mungkin. Oleh karena itu, keaktifan belajar siswa merupakan unsur dasar yang penting bagi keberhasilan proses pembelajaran.

Dalam kegiatan pembelajaran peserta didik tidak hanya dituntut keaktifannya saja tapi juga kreativitasnya, karena kreativitas dapat menciptakan situasi yang baru, tidak monoton dan menarik sehingga siswa akan lebih terlibat dalam kegiatan pembelajaran. Kreativitas dipandang sebuah proses mental. Daya kreativitas menunjuk pada kemampuan berpikir yang lebih orisinal dibanding dengan kebanyakan orang lain. Gagasan-gagasan yang kreatif, tidak muncul begitu saja, untuk dapat menciptakan sesuatu yang bermakna dibutuhkan persiapan. Masa seorang anak duduk di bangku sekolah termasuk masa persiapan ini karena mempersiapkan seseorang agar dapat memecahkan masalah-masalah.

Program Studi PGMI merupakan salah satu program studi terfavorit di STAIN Ponorogo yang memiliki visi sebagai pusat pendidikan dan pengembangan calon Guru MI/SD yang 
kompeten. Misi dari Program studi PGMI adalah; 1) melaksanakan proses pendidikan dan pembelajaran dalam bidang keguruan dan pendidikan Tingkat MI/SD secara profesional; 2) Mengembangkan ilmu kependidikan yang berkaitan dengan proses pembelajaran di MI/SD secara proporsional, dan; 3) Menciptakan iklim akademik yang Islami. Dalam rangka mencapai visi misi tersebut, mahasiswa diharapkan aktif dalam proses pembelajaran dan selalu mengembangkan pemikiran yang kreatif.

Dalam upaya pengembangan keaktifan dan kreativitas mahasiswa, diperlukan inovasi baru dalam pembelajaran yang relevan dengan keadaan mahasiswa saat ini. Proses pembelajaran dapat menggunakan strategi-strategi pembelajaran konstruktivistik yang berpotensi memberdayakan keaktifan dan kreativitas seperti model pembelajaran aktif (active learning) yang terintegrasi dengan pembelajaran berbasis internet (internet-based learning).

Pembelajaran aktif (active learning) pada dasarnya merupakan salah satu bentuk atau jenis dari pendekatan pembelajaran yang berorientasi pada aktivitas peserta didik. Pembelajaran berorientasi pada aktivitas peserta didik mengandung Pengertian bahwa sistem pembelajaran menempatkan peserta didik sebagai subyek didik yang aktif dan telah memiliki ke siapan untuk belajar. Active learning menjadikan peserta didik sebagai subyek belajar dan berpotensi untuk meningkatkan kreativitas atau lebih aktif dalam setiap aktivitas pelajaran yang diberikan, baik di dalam maupun di luar.

Dalam strategi ini peserta didik diarahkan untuk belajar aktif dengan cara menyentuh (touching), merasakan (feeling) dan melihat (looking) langsung serta mengalami sendiri sehingga pembelajaran lebih bermakna dan cepat dimengerti oleh peserta didik dan pendidik dalam hal ini dituntut juga untuk memotivasi peserta didik dan memberikan arahan serta menyediakan prasarana lengkap.

Pembelajaran berbasis internet merupakan salah satu manifestasi e-learning yang paling populer, yang menawarkan berbagai keuntungan seperti kesempatan belajar yang lebih fleksibel tanpa terikat ruang dan waktu, mempermudah masyarakat mengakses pendidikan, memperkaya materi pembelajaran, menghidupkan proses pembelajaran, membuat proses pembelajaran lebih terbuka, meningkatkan efektivitas pembelajaran, serta mendukung siswa untuk belajar mandiri. 
Pembelajaran berbasis internet dalam hal ini e-learning merupakan dasar dan konsekuensi logis dari perkembangan teknologi informasi dan komunikasi.

Dengan e-learning, peserta didik tidak perlu duduk dengan manis di ruang kelas untuk menyimak setiap ucapan dari seorang guru secara langsung. E-learning juga dapat mempersingkat jadwal target waktu pembelajaran, dan tentu saja menghemat biaya yang harus di keluarkan oleh sebuah program studi atau program pendidikan. Bagi Mahasiswa Prodi PGMI, setiap mata kuliah adalah salah satu mata kuliah yang sangat penting yang bertujuan untuk membekali mahasiswa calon S1 PGMI agar memiliki kompetensi menjadi pendidik di sekolah dasar.

Oleh karena itu, guna mempersiapkan calon S1 PGMI yang profesional, dosen harus mengembangkan kreativitas yang ada dalam diri mahasiswa dengan penerapan model pembelajaran yang sesuai. Berdasarkan penjelasan di atas, peneliti tertarik untuk memotret integrasi pembelajaran active learning dan internet-based learning pada pembelajaran dalam meningkatkan keaktifan dan kreativitas mahasiswa Prodi PGMI di STAIN Ponorogo.

\section{B. Telaah Pustaka}

1. Pembelajaran

Pembelajaran adalah suatu kegiatan yang dilakukan secara sadar dan sengaja. Adapun tujuan pembelajaran dalam bukunya Sugandi adalah membantu para siswa agar memperoleh berbagai pengalaman, dan dengan pengalaman itu tingkah laku yang dimaksud meliputi pengetahuan, keterampilan, dan nilai atau norma yang berfungsi sebagai pengendali sikap dan prilaku siswa

Dalam melaksanakan kegiatan pembelajaran tentunya banyak faktor yang mempengaruhi berhasil atau tidaknya. Faktor yang mempengaruhi belajar dibedakan menjadi dua golongan, yaitu faktor intern dan faktor ekstern. Faktor intern adalah faktor yang ada dalam diri individu yang sedang belajar, sedangkan faktor ekstern adalah yang berada di luar individu. Yang termasuk faktor Intern antara lain: faktor-faktor jasmaniah (faktor kesehatan dan cacat tubuh); psikologis (inteligensi, perhatian, minat, bakat, motif, kematangan, dan kesiapan); dan kelelahan (kelelahan jasmani dan rohani). Sedang yang termasuk faktor ekstern antara lain faktor 
keluarga (cara orang tua mendidik, relasi antar anggota keluarga, suasana rumah, keadaan ekonomi keluarga, Pengertian orang tua, dan latar belakang kebudayaan); sekolah (metode mengajar, kurikulum, disiplin, media pembelajaran, standar pelajaran di atas ukuran, keadaan gedung, metode mengajar, dan tugas rumah); dan faktor masyarakat (kegiatan siswa dalam masyarakat, media massa, teman bergaul, dan bentuk kehidupan masyarakat).

2. Pembelajaran Aktif (Active Learning)

Pembelajaranactivelearningpadadasarnyabukansebuahide yang baru lagi. Gagasan pembelajaran active learning telah ada sejak masa Socrates dan merupakan salah satu penekanan utama di antara para pendidik progresif seperti John Dewey yang memandang bahwa secara alami belajar merupakan proses yang aktif.

Meyersand Jones menyatakan bahwa "activelearning derives from two basic assumptions: (a) that learning is by its very nature an active process and (b) that different people learn in differentways. 'Dengan kata lain, bahwa pembelajaran pada dasarnya adalah pencarian secara aktif pengetahuan dan setiap orang belajar dengan cara yang berbeda.

Pembelajaran aktif (active learning) adalah suatu proses pembelajaran dengan maksud untuk memberdayakan peserta didik agar belajar dengan menggunakan berbagai cara/strategi secara aktif. Dalam hal ini proses aktivitas pembelajaran didominasi oleh peserta didik dengan menggunakan otak untuk menemukan konsep dan memecahkan masalah yang sedang dipelajari, di samping itu juga untuk menyiapkan mental dan melatih keterampilan fisiknya.

Cara memberdayakan peserta didik tidak hanya dengan menggunakan strategi atau metode ceramah saja, sebagaimana yang selama ini digunakan oleh para pendidik (guru) dalam proses pembelajaran. Mendidik dengan ceramah berarti memberikan suatu informasi melalui pendengaran, yang hanya bisa dicerna otak siswa $20 \%$. Padahal informasi yang dipelajari siswa bisa saja dari membaca(10\%), melihat $(30 \%)$, melihat dan dengar (50\%), mengatakan (70\%), mengatakan dan melakukan (90\%). Hal ini sesuai dengan pendapat seorang filosof Konfusius bahwa "Apa yang saya 
dengar, saya lupa" "Apa yang saya lihat, saya ingat" "Apa yang saya lakukan, saya paham".

Ketika ada informasi yang baru, otak manusia tidak hanya sekedar menerima dan menyimpan. Akan tetapi otak manusia akan memproses informasi tersebut sampai dapat dicerna dan baru kemudian disimpannya. Karena itu jika ada sesuatu yang baru, otak akan bertanya "pernahkah aku mendengar, melihat, mengalami sebelumnya, kapan dan di manakah kira-kira hal itu aku dengar, lihat dan ku alami lalu di manakah hal itu aku simpan?" Manusia dengan potensi dasar yang ia miliki termasuk otak tersebut perlu diaktifkan, sehingga berfungsi semaksimal mungkin melalui proses belajar yang ia lakukan.

Berdasarkan penjelasan di atas, dapat disimpulkan bahwa pembelajaran aktif adalah segala bentuk pembelajaran yang memungkinkan mahasiswa berperan secara aktif dalam proses pembelajaran itu sendiri baik dalam bentuk interaksi antar mahasiswa maupun mahasiswa dengan dosen dalam proses pembelajaran tersebut.

Menurut Bonwell pembelajaran aktif memiliki Karakteristik sebagai berikut:

a. Penekanan proses pembelajaran bukan pada penyampaian informasi oleh pengajar melainkan pada pengembangan keterampilan pemikiran analitis dan kritis terhadap topik atau permasalahan yang dibahas,

b. Mahasiswa tidak hanya mendengarkan kuliah secara pasif tetapi mengerjakan sesuatu yang berkaitan dengan materi kuliah,

c. Penekanan pada eksplorasi nilai-nilai dan sikap-sikap berkenaan dengan materi kuliah,

d. Mahasiswa lebih banyak dituntut untuk berpikir kritis, menganalisa dan melakukan evaluasi,

e. Umpan-balik yang lebih cepat akan terjadi pada proses pembelajaran.

Di samping Karakteristik tersebut di atas, secara umum suatu proses pembelajaran aktif mempunyai ciri-ciri sebagai berikut:

a. Situasi kelas menantang peserta didik melakukan kegiatan belajar secara bebas tapi terkendali. 
b. Pendidik tidak mendominasi pembicaraan tetapi lebih banyak memberikan rangsangan berpikir kepada peserta didik untuk memecahkan masalah.

c. Pendidik menyediakan dan mengusahakan sumber belajar bagi peserta didik, bisa sumber tertulis, sumber manusia, misalnya peserta didik itu sendiri menjelaskan permasalahan kepada peserta didik lainnya, berbagai media yang diperlukan, alat bantu pengajaran, termasuk pendidik sendiri sebagai sumber belajar.

d. Kegiatan belajar peserta didik bervariasi, ada kegiatan yang sifatnya bersama-sama dilakukan oleh semua peserta didik, ada kegiatan belajar yang dilakukan secara kelompok dalam bentuk diskusi dan ada pula kegiatan belajar yang harus dilakukan oleh masing-masing peserta didik secara mandiri. Penetapan kegiatan belajar tersebut diatur oleh guru secara sistematik dan terencana.

e. Pendidik menempatkan diri sebagai pembimbing semua peserta didik yang memerlukan bantuan manakala mereka menghadapi persoalan belajar.

f. Situasi dan kondisi kelas tidak kaku terikat dengan susunan yang mati, tapi sewaktu-waktu diubah sesuai dengan kebutuhan peserta didik

g. Belajar tidak hanya dilihat dan diukur dari segi hasil yang dicapai peserta didik tapi juga dilihat dan diukur dari segi proses belajar yang dilakukan siswa.

h. Adanya keberanian peserta didik mengajukan pendapatnya melalui pertanyaan atau pernyataan gagasannya, baik yang diajukan kepada pendidik maupun kepada peserta didik lainnya dalam pemecahan masalah belajar.

i. Pendidik senantiasa menghargai pendapat peserta didik terlepas dari benar atau salah. Bahkan pendidik harus mendorong peserta didik agar selalu mengajukan pendapatnya secara bebas.

Agar proses pembelajaran active learning bisa berjalan dengan baik, maka pendidik sebagai penggerak belajar peserta didik dituntut untuk menggunakan dan menguasai strategi pembelajaran active learning . Ada banyak strategi pembelajaran aktif dari mulai yang sederhana sampai dengan 
yang rumit. Beberapa jenis strategi pembelajaran tersebut antara lain adalah :

a. Poster comment (mengomentari gambar) yaitu suatu strategi yang digunakan pendidik dengan maksud mengajak peserta didik untuk memunculkan ide apa yang terkandung dalam suatu gambar. Gambar tersebut tentu saja berkaitan dengan pencapaian suatu kompetensi dalam pembelajaran. Dengan strategi ini peserta didik diharapkan dapat memberi masukan berupa pendapat/ide yang bervariasi karena setiap pikiran manusia itu berbeda-beda, dengan berbagai macam pendapat dari peserta didik tersebut akan dapat ditarik benang merahnya tentang inti pokok dari materi yang diajarkan.

b. Index Card Match (mencari pasangan jawaban) yaitu suatu strategi yang digunakan pendidik dengan maksud mengajak peserta didik untuk menemukan jawaban yang cocok dengan pertanyaan yang sudah disiapkan.

c. Active debate (debat aktif),strategi ini mendorong pemikiran dan perenungan terutama kalau peserta didik diharapkan memertahankan pendapat yang bertentangan dengan keyakinannya sendiri. Debat bisa menjadi satu metode berharga yang dapat mendorong pemikiran dan perenungan, terutama kalau peserta didik diharapkan dapat mempertahankan pendapat yang bertentangan dengan keyakinan mereka sendiri. Strategi ini dapat diterapkan kalau guru hendak menyajikan topik yang menimbulkan prokontra dalam mengungkapkan argumentasinya. Banyak kecakapan hidup yang dapat dilatih dengan strategi ini antara lain kemampuan berkomunikasi dan mengomunikasikan gagasannya kepada orang lain.

d. Everyone is Teacher Here (semua adalah pendidik) yaitu strategi yang digunakan oleh pendidik dengan maksud meminta peserta didik untuk semuanya berperan menjadi narasumber terhadap sesama temannya di kelas belajar. Strategi ini bertujuan untuk memberikan kesempatan yang sama kepada setiap peserta didik untuk berperan sebagai guru bagi kawannya. Dengan ini diharapkan agar peserta didik yang pasif dapat ikut terlibat dalam pembelajaran aktif. 
e. Team Quiz, strategi ini mendorong siswa untuk aktif dalam kelompok untuk membuat pertanyaan serta jawaban sesuai dengan kompetensi yang diharapkan.

f. Role Playatau bermain peran adalah strategi pembelajaran sebagai bagian dari simulasi yang diarahkan untuk mengkreasi peristiwa sejarah, mengkreasi peristiwaperistiwa aktual, atau kejadian-kejadian yang mungkin muncul pada masa mendatang. Topik yang dapat diangkat untuk role play misalnya memainkan peran sebagai juru kampanye suatu partai atau gambaran keadaan yang mungkin muncul di masyarakat.

g. Peer Teaching,merupakan latihan mengajar yang dilakukan oleh mahasiswa kepada teman-teman calon guru. Selain itu peerteaching merupakan kegiatan pembelajaran yang dilakukan seorang siswa kepada siswa lainnya dan salah satu siswa itu lebih memahami materi pembelajaran.

h. Student-led Review Session. Strategi ini digunakan untuk memberikan peran kepada mahasiswa sebagai pengajar. Dosen hanya bertindak sebagai narasumber dan fasilitator. Strategi ini dapat digunakan pada sesi review terhadap materi kuliah. Pada bagian pertama dari kuliah kelompokkelompok kecil mahasiswa diminta untuk mendiskusikan hal-hal yang dianggap belum dipahami dari materi tersebut dengan mengajukan pertanyaan-pertanyaan dan mahasiswa yang lain menjawabnya. Kegiatan kelompok dapat juga dilakukan dalam bentuk salah satu mahasiswa dalam kelompok tersebut memberikan ilustrasi bagaimana suatu rumus atau metode digunakan. Kemudian pada bagian kedua kegiatan ini dilakukan untuk seluruh kelas. Proses ini dipimpin oleh mahasiswa dan dosen lebih berperan untuk mengklarifikasi hal-hal yang menjadi bahasan dalam proses pembelajaran tersebut.

i. Jigsaw, yaitu strategi kerja kelompok yang terstruktur didasarkan pada kerjasama dan tanggungjawab. Kelebihan strategi ini adalah dapat melibatkan seluruh siswa dan setiap peserta didik memikul suatu tanggung jawab yang signifikan dalam kelompok.

j. Reading Guide (penuntun bacaan). Strategi ini digunakan pendidik dengan maksud mengajak peserta didik untuk 
mempelajari sesuatu dengan cara membaca suatu teks bacaan (buku, majalah, koran dan lain-lain) sesuai dengan materi bahasan.

k. Card Sort (menyortir kartu). Yaitu strategi yang digunakan oleh pendidik dengan maksud mengajak peserta didik untuk menemukan konsep dan fakta melalui klasifikasi materi yang dibahas dalam pembelajaran.

1. Concept Mapping (peta konsep). Suatu cara yang digunakan oleh pendidik dengan maksud meminta peserta didik untuk membuat konsep atau kata-kata kunci dari suatu pokok persoalan sebagai rumusan inti pelajaran.

m. Information Search (mencari informasi) yaitu suatu cara yang digunakan oleh guru dengan maksud meminta peserta didik untuk menjawab pertanyaan-pertanyaan yang diajukan baik oleh pendidik maupun peserta didik sendiri, kemudian mencari informasi jawabannya lewat membaca untuk menemukan informasi yang akurat.

n. Demonstration (Demonstrasi). Suatu presentasi yang dipersiapkan dengan hati-hati untuk memperlihatkan bagaimana berprilaku atau menggunakan suatu prosedur atau alat. Presentasi dilengkapi dengan penjelasan lisan dan atau alat visual, ilustrasi dan pertanyaan.

o. Think-Pair-Share, dengan cara ini mahasiswa diberi pertanyaan atau soal untuk dipikirkan sendiri kurang lebih 2-5 menit (think), kemudian mahasiswa diminta untuk mendiskusikan jawaban atau pendapatnya dengan teman yang duduk di sebelahnya (pair). Setelah itu, pengajar dapat menunjuk satu atau lebih mahasiswa untuk menyampaikan pendapatnya atas pertanyaan atau soal itu bagi seluruh kelas (share).

3. Pembelajaran Berbasis Internet (Internet-Based Learning)

Internet-based learning adalah segala pemanfaatan atau penggunaan teknologi internet dan Wet untuk menciptakan pengalaman pembelajaran. Dengan kata lain, internet-based learning merupakan suatu jenis belajar mengajar yang memungkinkan tersampaikannya bahan ajar ke siswa dengan menggunakan media internet.

Rosenberg menekankan bahwa internet-based learning merujuk pada penggunaan teknologi internet untuk mengirimkan serangkaian solusi yang dapat meningkatkan 
pengetahuan dan keterampilan. Internet-based learning merupakan bentuk manifestasi dari konsep e-learning. Hal ini senada dengan Cambell yang intinya menekankan penggunaan internet dalam pendidikan sebagai hakikat e-learning. Bahkan Onno W. Menjelaskan bahwa istilah " $e$ " atau singkatan dari elektronik dalam e-learning digunakan sebagai istilah untuk segala teknologi yang digunakan untuk mendukung usaha-usaha pengajaran lewat teknologi elektronik internet.

Adapun yang menjadi Karakteristik dari pembelajaran berbasis internet (internet-based learning), antara lain; a) Memanfaatkan jasa teknologi elektronik; di mana pendidik dan peserta didik, peserta didik dan sesama peserta didik atau dapat berkomunikasi dengan relatif mudah dengan tanpa dibatasi oleh hal-hal yang protokoler; b) Memanfaatkan keunggulan komputer (digital media andcomputernetworks); c) Menggunakan bahan ajar bersifat mandiri (self learning materials) disimpan di komputer sehingga dapat diakses oleh pendidik dan peserta didik kapan saja dan di mana saja bila yang bersangkutan memerlukannya; d) Memanfaatkan jadwal pembelajaran, kurikulum, hasil kemajuan belajar dan hal-hal yang berkaitan dengan administrasi pendidikan dapat dilihat setiap saat di komputer.

Manfaat pembelajaran berbasis internet (internet-based learning) menurut Bates (1995) dan Wulf (1996) terdiri atas 4 hal, yaitu; a) Meningkatkan kadar interaksi pembelajaran antara peserta didik dengan guru atau instruktur (enhance interactivity), (b) Memungkinkan terjadinya interaksi pembelajaran dari mana dan kapan saja (time and place flexibility); c) Menjangkau peserta didik dalam cakupan yang luas (potential to reach a global audience); d) Mempermudah penyempurnaan dan penyimpanan materi pembelajaran (easy updating of content as well as archivable capabilities).

Ada3(tiga) fungsi internet-based learning terhadapkegiatanpembelajarandidalamkelas,yaitu sebagai tambahan(suplemen),pelengkap(komplemen), atau pengganti (substitusi). Dikatakan berfungsi sebagai suplemen (tambahan),apabila peserta didik mempunyai kebebasan memilih, Apakah akan memanfaatkan materi e-learning atau tidak. Dalam hal ini, tidak ada kewajiban/keharusan bagi peserta didik untuk 
mengakses materi internet-based learning. Sebagai komplemen berarti materi e-learning diprogramkan untuk menjadi materi reinforcement (pengayaan) atau remedial bagi peserta didik di dalam mengikuti kegiatan pembelajaran konvensional. Materi internet-based learning juga dapat berfungsi sebagai enrichment, apabila kepada peserta didik yang dapat dengan cepat menguasai atau memahami materi pelajaran yang disampaikan guru secara tatap muka (fastlearners) diberikan kesempatan untuk mengakses materi internet-based learning yang memang secara khusus dikembangkan untuk mereka.

4. Keaktifan Belajar

Keaktifan berasal dari kata aktif yang berarti giat atau sibuk. Kata keaktifan juga bisa berarti dengan kegiatan dan kesibukan. Yang dimaksud dengan keaktifan di sini adalah bahwa pada waktu pendidik mengajar ia harus mengusahakan agar peserta didiknya aktif jasmani maupun rohani.

Dalam proses pembelajaran peserta didik dituntut untuk aktif, penilaian proses pembelajaran terutama melihat sejauh mana keaktifan peserta didik dalam mengikuti proses pembelajaran. Perihal tentang keaktifan belajar menurut Nana Sudjana di antaranya:

a. Turut serta dalam melaksanakan tugas belajarnya

b. Terlibat dalam pemecahan masalah

c. Bertanya kepada peserta didik lain atau kepada guru apabila tidak memahami persoalan yang dihadapinya

d. Berusaha mencari berbagai informasi yang diperlukan untuk pemecahan masalah

e. Melaksanakan diskusi kelompok sesuai petunjuk guru

f. Menilai kemampuan dirinya dan hasil-hasil yang diperolehnya

g. Melatih diri dalam memecahkan soal atau masalah sejenis

h. Kesempatan menggunakan atau menerapkan apa yang diperolehnya dalam menyelesaikan tugas atau persoalan yang dihadapi.

Berdasarkan beberapa pendapat di atas dapat disimpulkan bahwa keaktifan belajar adalah segala kegiatan yang dilakukan dalam proses pembelajaran yaitu proses interaksi (pendidik dan peserta didik) dalam rangka memperoleh hasil 
belajar berupa perpaduan antara aspek kognitif, afektif dan psikomotor.

Munir mengelompokkan keaktifan peserta didik ini menjadi beberapa aspek, antara lain yaitu; a) aktif secara jasmani seperti penginderaan, yaitu mendengar, melihat, mencium, merasa, dan meraba atau melakukan keterampilan jasmaniah; b) aktif berpikir melalui tanya jawab, mengolah dan mengemukakan ide, berpikir logis, sistematis, dan sebagainya; dan c) aktif secara sosial seperti aktif berinteraksi atau bekerjasama dengan orang lain .

5. Kreativitas Belajar

Pengertian kreativitas sudah banyak dikemukakan oleh para ahli berdasarkan pandangan yang berbeda-beda, seperti yang dikemukakan oleh Utami Munandar menjelaskan Pengertian kreativitas dengan mengemukakan beberapa perumusan yang merupakan kesimpulan para ahli mengenai kreativitas.

Pertama, kreativitas adalah kemampuan untuk membuat kombinasi baru berdasarkan data, informasi, atau unsur-unsur yang ada. Kedua, kreativitas (berpikir kreatif atau berpikir divergen) adalah kemampuan berdasarkan data atau informasi yang tersedia, menemukan banyak kemungkinan jawaban terhadap suatu masalah, di mana penekanannya adalah pada kuantitas, ketepatgunaan, dan keragaman jawaban. Ketiga secara operasional kreativitas dapat dirumuskan sebagai kemampuan yang mencerminkan kelancaran, keluwesan (fleksibilitas), dan orisinalitas dalam berpikir, serta kemampuan untuk mengelaborasi (mengembangkan, memperkaya, merinci) suatu gagasan.

\section{Telaah Penelitian Terdahulu}

Penelitian yang dilakukan oleh Puput Dwi Maret Tanti yang bertujuan untuk meningkatkan kreativitas belajar biologi siswa kelas XI A3 SMA Negeri 1 Ngemplak Boyolali melalui penerapan pembelajaran aktif (active learning) dengan metode Mind Map. Penelitian ini merupakan penelitian tindakan kelas yang dilaksanakan dalam dua siklus. Hasil penelitian menunjukkan bahwa pelaksanaan tindakan kelas melalui penerapan pembelajaran aktif (active learning) dengan metode Mind Map dapat meningkatkan kreativitas belajar biologi siswa kelas XI A3 
SMA Negeri 1 Ngemplak Boyolali. Hal ini didasarkan pada hasil observasi, angket, dan wawancara. Rata-rata nilai persentase setiap indikator yang didapatkan dari hasil observasi kreativitas belajar siswa untuk siklus I sebesar 76\% dan siklus II sebesar 84,67\% (meningkat 8,67\%). Rata-rata nilai persentase setiap indikator dari angket kreativitas belajar siswa untuk siklus I 77,43\% dan siklus II 78,87\% (meningkat $1,44 \%$ ).

Selanjutnya, Tatmimatun Ni'mah, Triyono dan Joharman melakukan penelitian tentang Penerapan Metode Index Card Match untuk Meningkatkan Keaktifan dalam Pembelajaran IPS Siswa Kelas IV SD. Penelitian ini bertujuan: mendeskripsikan proses pembelajaran, keaktifan dalam pembelajaran IPS. Penelitian dilaksanakan dalam tiga siklus. Subjek penelitian ini adalah seluruh siswa kelas IV SD Negeri 1 Petanahan yang berjumlah 21 siswa. Sumber data berasal dari siswa, teman sejawat dan peneliti. Teknik pengumpulan data menggunakan observasi, dokumentasi dan tes. Validitas data menggunakan teknik triangulasi metode dan sumber. Analisis data yang digunakan dengan analisis kualitatif dan kuantitatif. Hasilnya menunjukkan bahwa penerapan metode index card match, dapat meningkatkan keaktifan siswa dalam pembelajaran IPS di kelas IV.

Donna Carolina melaksanakan penelitian tindakan kelas dengan memvariasikan metode active learning di kelas dengan $e$ learning (web). Subjek penelitian ini adalah siswa kelas X AP 1 SMK Negeri 2 Semarang. Rancangan kegiatan penelitian ini adalah siklus kegiatan yang terdiri dari tiga siklus. Instrumen pengumpulan data yang dalam penelitian ini adalah lembar observasi guru, siswa dan proses untuk mengukur kualitas iklim pembelajaran aktif dan tes untuk mengukur hasil belajar yang berlangsung tiap siklusnya. Hasil penelitian diperoleh rata-rata tingkat kualitas pembelajaran aktif yang tercipta pada siklus I sebesar $55.3 \%$, pada siklus II sebesar $73.27 \%$ dan pada siklus III mengalami peningkatan menjadi $86.82 \%$ dengan kategori sangat baik. Hasil analisis regresinya membuktikan pengaruh pembelajaran aktif terhadap hasil belajar dengan persamaan $\mathrm{Y}=$ $22.028+1.601 \mathrm{X}$ dengan nilai R2 0.857 dan nilai probabilitas FTest 0.00 di bawah 0.05 yang artinya pembelajaran aktif berpengaruh secara signifikan terhadap hasil belajar dan dapat menjelaskan variasinya sebesar $85.7 \%$. Kesimpulan penelitian ini strategi active learning berbasis web (blended learning) terbukti 
mampu menciptakan pembelajaran aktif yang berkualitas dan berpengaruh terhadap peningkatan hasil belajar.

Azwar Rhosyied, dan Bambang Wijanarko Otok mengadakan penelitian yang bertujuan mengkaji dampak penggunaan internet sebagai media belajar terhadap prestasi belajar siswa. Sumber data penelitian ini adalah siswa SMA Negeri 1 Probolinggo. Sampel diambil secara random dengan metode sampling stratifikasi proporsional berdasarkan kelas. Sebanyak 195 siswa terambil sebagai responden dengan rincian kelas X 69 siswa, kelas XI 69 siswa dan kelas XII 57 siswa. Variabel yang digunakan adalah variabel karakteristik demografi, variabel perilaku penggunaan internet dan 4 variabel laten sebagai input untuk analisis SEM, yaitu Internet sebagai Media Belajar (MI), Motivasi Belajar (MB), Kreativitas (KR), dan Prestasi Belajar (PB). Metode analisis yang dipakai adalah Confirmatory Factor Analysis (CFA) untuk mengkonfirmasi indikator terhadap variabel laten. Model Structural Equation Modeling (SEM) untuk mengetahui besar ukuran pengaruh variabel laten ke variabel laten lain. Hasil yang diperoleh adalah penggunaan internet sebagai media belajar berpengaruh positif terhadap motivasi belajar, kreativitas serta berpengaruh secara tidak langsung terhadap prestasi belajar.

Berdasarkan penelitian terdahulu di atas, peneliti mencoba mengintegrasikan strategi pembelajaran aktif (active learning) dan pembelajaran berbasis internet (internet-based learning) untuk meningkatkan keaktifan dan kreativitas mahasiswa dalam proses pembelajaran.

\section{Metode Penelitian}

Jenis penelitian ini merupakan penelitian deskriptif kualitatif. Adapun yang menjadi subjek dari penelitian ini adalah mahasiswa kelas PG.C semester 4 Prodi PGMI dan dosen yang mengintegrasikan pembelajaran active learning dan internet based learning yaitu, EYW pada mata kuliah Pembelajaran IPA di MI, MSH pada mata kuliah IPS 1 dan ME pada mata kuliah Strategi Belajar Mengajar.

Dalam penelitian ini, instrumen utama adalah peneliti sendiri, karena dalam penelitian jenis kualitatif kehadiran peneliti sebagai instrumen adalah mutlak diperlukan. Peran peneliti adalah sebagai partisipan penuh, bisa juga sebagai pengamat, partisipan dan kehadiran peneliti diketahui sebagai subyeknya. Data dalam 
penelitian ini adalah interaksi antara dosen dan mahasiswa pada mata kuliah. Sumber data dalam penelitian yaitu subyek dari mana data dapat diperoleh dan sumber data dibagi menjadi 2 yaitu sumber primer dan sekunder. Sumber Primer adalah sumbersumber dasar yang merupakan bukti atau saksi utama dan kejadian yang lalu. Sumber Primer dalam penelitian ini, meliputi: dosen pengampu mata kuliah dan mahasiswa pada prodi PGMI STAIN Ponorogo. Adapun dosen pengampuh mata kuliah yang dijadikan sumber primer adalah; 1) MSH pada mata kuliah pembelajaran IPS 1; 2) EYW pada mata kuliah pembelajaran IPA, dan ;3) ME pada mata kuliah Strategi Belajar Mengajar. Sumber Sekunder adalah sumber yang digunakan oleh penulis untuk mendukung dan menunjang pembahasan dalam penelitian ini. Seperti tentang buku active learning dan internet-based learning. Dalam upaya pengumpulan data, peneliti menggunakan beberapa metode yaitu observasi, interview dan dokumentasi.

Dalam proses analisis data, peneliti menggunakan metode analisis kualitatif, yaitu analisis data yang dilaksanakan dengan jalan menggambarkan, melukiskan dan menguraikan secara mendalam keadaan yang sebenarnya di lapangan atau peristiwa yang terjadi. Miles dan Huberman analisis kualitatif meliputi: data collection period, data reduction, data display, and conclussion drawing/verification. Teknik keabsahan data dalam penilaian ini adalah tringulasi data. Menurut Lexy Moleong, tringulasi berupaya untuk mengecek kebenaran data dan membandingkan dengan data yang diperoleh dengan sumber lain, pada berbagai fase penelitian di lapangan, pada waktu yang berlainan dengan tiga macam teknik pemeriksaan yang memanfaatkan penggunaan sumber data, metode, dan teori.

Untuk itu maka peneliti dapat melakukannya dengan jalan mengajukan berbagai macam variasi pertanyaan, mengecek dengan berbagai sumber data atau memanfaatkan berbagai metode agar pengecekan kepercayaan data dalam penelitian dapat dilakukan.

\section{E. Pembahasan}

1. Integrasi Pembelajaran Active Learning dan Internet-Based Learning Prodi PGMI STAIN Ponorogo

Berdasarkan hasil observasi selama proses pembelajaran dan interview terhadap 3 dosen yang mengampuh mata kuliah 
di Prodi PGMI dapat diketahui bahwa dalam pelaksanaan pembelajaran di kelas dosen menerapkan model pembelajaran active learning untuk mengembangkan kemampuan berpikir analitis mahasiswa dan kapasitas mahasiswa dalam menggunakan kemampuan pada materi-materi kuliah yang diberikan. Di samping itu, pembelajaran internet-based learning diwujudkan dalam bentuk pemakaian situs web seperti yahoo, google, wikipedia, dan youtube untuk mendukung proses pembelajaran. Dalam hal ini, internet dipakai baik sebagai media maupun sumber belajar.

Hasil observasi kegiatan pembelajaran pada mata kuliah IPS-1 di kelas PG-C prodi PGMI dengan dosen pengampu MSH pada Senin, 13 Mei 2013 07.00-09.30 pada pokok bahasan Antropologi menunjukkan penerapan model active learning dengan strategi "information search" yaitu suatu cara yang digunakan oleh dosen dengan maksud meminta mahasiswa untuk mencari informasi dengan cara membaca dari berbagai sumber untuk menemukan informasi yang akurat. Adapun langkah-langkah pembelajaran yang diterapkan dalam strategi Information Search adalah:

a. Dosen memberikan apersepsi tentang pengertian dan manfaat antropologi

b. Dosen membagi mahasiswa menjadi 3 kelompok dan diberikan lembar kerja yang berisikan subtopik antropologi

c. Dosen meminta mahasiswa untuk membaca referensi baik dari buku ajar maupun sumber belajar dari internet untuk mencari informasi yang berhubungan dengan subtopik yang terdapat di lembar kerja secara berkelompok.

d. Dosen meminta setiap kelompok untuk mempresentasikan hasil kerja dan memberikan kesempatan bagi kelompok lain untuk memberikan tanggapan.

e. Dosen memberikan penguatan.

Hampir seluruh mahasiswa berpartisipasi aktif dalam diskusi dan mencari informasi untuk mengisi lembar kerja dengan cara mengakses internet baik melalui telepon seluler maupun laptop yang terkoneksi oleh jaringan internet. Sedangkan kreativitas belajar mahasiswa juga muncul pada saat tahap presentasi, yaitu dengan penyampaian ide-ide yang merupakan kombinasi baru berdasarkan data, informasi, atau 
unsur-unsur yang diperoleh dari hasil membaca dengan menggunakan bahasa yang lugas dan mudah dipahami.

Hasil observasi kedua pada proses pembelajaran mata kuliah IPS-1 dilakukan pada hari Senin, tanggal 27 Mei 2013 pukul 07.00-09.30 di kelas PG-C pada pokok bahasan psikologi sosial, dosen menerapkan model pembelajaran $a c$ tive learning dalam bentuk strategi "Role play", di mana mahasiswa harus membuat skenario yang akan diperankan di depan kelas berdasarkan gambar situasi tentang peristiwa psikologi sosial yang terjadi di masyarakat. Adapun langkahlangkah dari Role play sebagai berikut:

a. Dosen memberikan apersepsi tentang peristiwa psikologi sosial

b. Dosen membagi kelas menjadi 5 kelompok

c. Dosen membagikan gambar tentang peristiwa psikologi sosial yang terjadi di Indonesia pada setiap kelompok sebagai acuan pembuatan skenario yang akan ditampilkan di depan kelas.

d. Dosen meminta mahasiswa untuk bermain peran sesuai dengan skenario yang telah dibuat

e. Dosen meminta setiap kelompok untuk memberikan komentar serta konsep psikologi sosial apa yang ingin diangkat dalam tampilan tersebut

f. Dosen memberikan penguatan.

Mahasiswa terlibat aktif dalam pembuatan skenario role play. Mahasiswa sangat antusias untuk bertukar ide dengan kelompoknya tentang bentuk tampilan dari bermain peran. Meskipun, terdapat beberapa mahasiswa yang nampak bercanda dan ada juga mahasiswa yang hanya berdiam saja. Di samping itu, keterampilan mahasiswa untuk memperinci atau mengelaborasi konsep dari psikologi sosial yang terdapat dalam gambar untuk diterjemahkan ke dalam skenario dan tampilan di depan kelas.

Berdasarkan hasil observasi pada proses pembelajaran mata kuliah Strategi Belajar Mengajar pada hari Selasa, tanggal 14 Mei 2013 pukul 07.30-09.00 di kelas PG-C dengan pokok bahasan Pembelajaran Kontekstual/CTL, dosen menerapkan model pembelajaran active learning dalam bentuk strategi "jigsaw" yaitu strategi kerja kelompok yang 
berstruktur didasarkan pada kerjasama dan tanggung jawab. Prosedur pembelajarannya adalah:

a. Dosen membagi mahasiswa satu kelas dibagi menjadi 4 kelompok sebagai home team.

b. Dosen membentuk 4 tim ahli yang beranggotakan perwakilan dari masing-masing home team.

c. Masing-masing tim ahli mendiskusikan sub topik dari pembelajaran CTL.

d. Setelah selesai berdiskusi dengan tim ahli, mereka kembali ke home team dan secara bergantian mempresentasikan hasil diskusinya dengan tim ahli. Home team membuat rangkuman materi berdasarkan keterangan tersebut.

e. Dosen menunjuk beberapa mahasiswa secara acak untuk menjelaskan hasil diskusi dalam home team.

f. Dosen memberikan penguatan.

Keaktifan mahasiswa terlihat selama berdiskusi baik dalam home team maupun dalam tim ahli meskipun terdapat beberapa mahasiswa yang kurang mengikuti kegiatan tersebut. Untuk melengkapi informasi mengenai CTL yang terdapat dalam buku ajar, mahasiswa juga aktif melakukan browsing internet melalui yahoo dan google.

Hasil observasi kedua pada proses pembelajaran mata kuliah Strategi Belajar Mengajar pada hari Selasa, tanggal 21 Mei 2013 pukul 07.30-09.00 di kelas PG-C pada pokok bahasan pembelajaran aktif/active learning. Dosen menggunakan strategi Demonstrasi "Demonstrastion" di mana panduan atau prosedur dari setiap strategi mengenai model pembelajaran aktif telah diupload di internet melalui platform Edmodo. Langkah-langkah pembelajarannya adalah sebagai berikut:

a. Dosen melakukan curah pendapat tentang model-model pembelajaran.

b. Dosen membagi mahasiswa menjadi 10 kelompok dalam platform Edmodo dan meminta mahasiswa untuk mengaksesnya melalui jaringan internet

c. Dosen membagikan lembar kerja yang berisikan langkahlangkah pembelajaran aktif yang telah diuplod di Edmodo dan meminta mahasiswa untuk mengunduhnya. 
d. Dosen meminta mahasiswa mendiskusikan langkah-langkah pembelajaran tersebut dan dipraktekkan dalam kelas dalam bentuk "demonstration".

e. Setiap kelompok melakukan demonstrasi strategi dalam model pembelajaran active learning

f. Dosen beserta mahasiswa memberikan komentar dan feedback

g. Dosen memberikan penguatan

Mahasiswa berpartisipasi aktif dalam sharing ide untuk memahami strategi yang akan didemonstrasikan. Mahasiswa juga sangat kreatif dalam penggunaan media maupun materi yang menarik tentang pembelajaran di MI yang mereka unduh dari internet.

Hasil observasi proses pembelajaran Mata Kuliah Pembelajaran IPA di MI dengan pokok Bahasan Pembelajaran Materi Struktur Bumi dan Batuan di MI di kelas PG-C dengan dosen Pengampuh EYW dilaksanakan pada hari Kamis, tanggal 16 Mei 2013 pukul 09.00-10.30 dengan menggunakan model active learning dengan strategi concept mapping sebagai cara yang digunakan oleh dosen dengan maksud meminta mahasiswa untuk membuat konsep atau kata-kata kunci dari suatu pokok persoalan sebagai rumusan inti pelajaran. Di samping itu, dosen juga mengundur berbagai gambar melalui google sebagai media untuk apersepsi. Adapun langkah-langkah pembelajarannya sebagai berikut:

a. Dosen memberikan apersepsi tentang Materi Struktur Bumi dan Batuan

b. Dosen membagi kelas menjadi 12 kelompok.

c. Dosen membagikan kertas plano dan spidol warna-warni sebagai lembar kerja untuk membuat peta konsep.

d. Dosen meminta mahasiswa untuk bekerjasama dalam kelompok menuangkan ide dalam bentuk peta konsep berdasarkan subtopik yang telah ditentukan.

e. Dosen meminta setiap kelompok untuk mempresentasikan peta konsep yang dibuat di kertas plano.

f. Dosen memberikan kesempatan kepada kelompok lain untuk memberikan komentar.

g. Dosen memberikan penguatan.

Mahasiswa aktif terlibat untuk berdiskusi guna membuat peta konsep yang menarik pada kertas plano dan browsing 
melalui internet untuk mencari informasi yang sesuai dengan topik yang diberikan. Kreativitas mahasiswa dapat dilihat dalam tampilan di depan kelas dengan peta konsep yang dibuat sangat menarik dan atraktif.

Hasil observasi kedua pada proses pembelajaran mata kuliah Pembelajaran IPA di MI dilakukan pada hari Kamis, tanggal 30 Mei 2013 pukul 09.00-10.30 di kelas PG-C dengan pokok Bahasan Pembelajaran Matahari sebagai pusat Tata Surya menunjukkan bahwa dosen menerapkan strategi peer teaching yang merupakan latihan mengajar yang dilakukan oleh mahasiswa kepada teman-teman mahasiswa lain, dengan prosedur sebagai berikut:

a. Dosen memberikan apersepsi dengan menggunakan media video dan gambar tentang sistem tata surya.

b. Dosen membagi kelas menjadi 2 kelompok

c. Dosen menjelaskan bahwa mahasiswa harus berlatih menjadi guru untuk menjelaskan materi yang telah ditentukan

d. Setiap kelompok harus menunjuk 3 anggota kelompoknya untuk menjelaskan dan anggota kelompok lain menjadi pengamat dan siswa.

e. Dosen dan beberapa mahasiswa memberikan komentar atas tampilan tersebut.

f. Dosen memberikan penguatan

Media yang dipakai adalah video yang disajikan menggunakan LCD. Video tersebut tentang proses gerhana bulan dan matahari yang diunduh lewat internet tepatnya di youtube. Kreativitas mahasiswa terlihat saat menjelaskan dengan bantuan media video tersebut. Di sisi lain, mahasiswa juga berperan aktif baik sebagai guru, pengamat dan mahasiswa selama proses peer teaching.

2. Faktor Pendukung dan Penghambat Pembelajaran active learning dan internet-based learning Prodi PGMI STAIN Ponorogo

Berdasarkan hasil observasi kegiatan yang mengintegrasikan pembelajaran active learning dan internet-based learning serta wawancara kepada 3 dosen pada prodi PGMI dapat diketahui beberapa faktor pendukung dan penghambat selama proses pembelajaran. 
a. Faktor Pendukung integrasi pembelajaran active learning dan internet-based learning

Pertama, perlunya mempertimbangkan strategi pembelajaran pada model active learning. Setiap strategi pada pembelajaran active learning memerlukan persiapanpersiapan yang berbeda tingkat kemudahannya begitu pula dalam pelaksanaannya. Oleh sebab itu, perlu dipertimbangkan dengan baik strategi yang akan dipergunakan. Beberapa hal yang dapat dijadikan pertimbangan dalam memilih strategi pembelajaran adalah tujuan pembelajaran, aktivitas, pengetahuan awal mahasiswa, alokasi waktu dan sarana penunjang.

Kedua, Memberikan pengarahan yang jelas, dikarenakan sebagian besar strategi dalam model pembelajaran $a c$ tive learning adalah kerjasama untuk berdiskusi dalam kelompok, maka diskusi dalam kelas merupakan tanggung jawab dosen untuk menjaganya dalam alur dan tempo yang baik, sehingga pengarahan yang singkat dan jelas mempengaruhi kesuksesan setiap proses pembelajaran.

Ketiga, motivasi belajar mahasiswa yang tinggi, motivasi memegang peranan penting dalam kegiatan pembelajaran. Kegiatan pembelajaran active learning akan berhasil baik jika mahasiswa memiliki motivasi yang tinggi dalam belajar. Di samping itu, motivasi belajar yang tinggi akan mendorong mahasiswa untuk aktif berpartisipasi pada pembelajaran dalam setiap strategi dalam model active learning supaya mahasiswa dapat memperoleh hasil pembelajaran secara efektif dan optimal.

Keempat, ketersediaan sarana dan prasarana yang memadai, dikarenakan kegiatan pembelajaran dilakukan melalui pemanfaatan jaringan internet, maka dibutuhkan jaringan yang kuat sehingga mahasiswa dapat mengkases informasi secara cepat. Di samping itu, ketersediaan perangkat lain seperti laptop, LCD serta media pendukung lainnya juga sangat diperlukan.

b. Faktor Penghambat integrasi pembelajaran active learning dan internet-based learning

Pertama, keterbatasan waktu, konsep dasar dari pembelajaran active learning adalah segala bentuk 
pembelajaran yang memungkinkan mahasiswa berperan secara aktif dalam proses pembelajaran itu sendiri baik dalam bentuk interaksi antar mahasiswa maupun mahasiswa dengan dosen dalam proses pembelajaran tersebut. Sehingga, dibutuhkan waktu yang cukup panjang agar seluruh mahasiswa dapat berpartisipasi aktif. Dalam perkuliahan diberikan waktu 90 menit pada setiap pertemuan. Sehingga dengan waktu 90 menit dan jumlah mahasiswa sebanyak 31, para dosen sering mengeluhkan tentang hal tersebut. Apalagi bila ada penataan ruang belum terkondisi dengan baik untuk kerja kelompok, sehingga perlu waktu merubah posisi yang dapat juga menimbulkan gaduh.

Kedua, dominasi mahasiswa yang pintar. Pembelajaran active learning ditujukan agar mahasiswa secara aktif bertanya dan menyatakan pendapat dengan aktif selama proses pembelajaran, sehingga saat berdiskusi kelompok nampak hanya beberapa mahasiswa yang mendominasi untuk aktif menyatakan pendapat. Hal yang paling mencolok lainnya adalah ketika diminta perwakilan dari kelompok untuk presentasi di depan kelas, mahasiswa yang menjadi penyaji hampir selalu sama yaitu mahasiswa yang masuk kategori pintar saja. Kebanyakan mahasiswa masih ragu-ragu dan belum percaya diri untuk belajar kelompok serta mengungkapkan pendapat.

Ketiga, ketidaksiapan mahasiswa dalam menerima materi baru, Pembelajaran active learning memiliki konsekuensi pada mahasiswa untuk mempersiapkan diri dengan baik di luar jam kuliah. Mahasiswa memiliki tanggungjawab yang besar untuk mencari seluas-luasnya materi yang melatarbelakangi perkuliahan sehingga dapat berpartisipasi dengan baik dalam perkuliahan. Tetapi, pada taraf praktek di dalam kelas, sebagian mahasiswa tidak siap dalam menerima materi baru yang disampaikan melalui strategi active learning karena mereka kurang mempersiapkan diri di luar jam kuliah meskipun pada saat awal kuliah atau pada saat menjelaskan $\mathrm{CO}$ mahasiswa telah diberi penjelasan apa yang akan dilakukan selama proses pembelajaran. 


\section{F. Penutup}

Integrasi pembelajaran active learning dan internet-based learning yang dapat meningkatkan keaktifan dan kreativitas belajar mahasiswa di Prodi PGMI STAIN Ponorogo dalam bentuk penggunaan strategi pembelajaran yang mengembangkan kemampuan berpikir analitis dari mahasiswa yaitu information search dan role play pada mata kuliah IPS1, Jigsaw dan demonstration pada mata kuliah Strategi Belajar Mengajar, concept mapping dan peer teaching pada mata kuliah Pembelajaran IPA di MI. Di samping itu, untuk mendukung proses pembelajaran, baik dosen maupun mahasiswa memanfaatkan situs web seperti yahoo, google, wikipedia, youtube dan edmodo. Dalam hal ini, internet dipakai baik sebagai media maupun sumber belajar.

Faktor pendukung integrasi pembelajaran active learning dan internet-based learning di antaranya perlunya mempertimbangkan strategi pembelajaran pada model active learning, pemberian pengarahan yang jelas, motivasi belajar mahasiswa yang tinggi dan tersedianya sarana dan prasarana pembelajaran. Sedangkan faktor penghambat integrasi pembelajaran active learning dan internet-based learning adalah keterbatasan waktu, dominasi mahasiswa yang pintar dan ketidaksiapan mahasiswa dalam menerima materi baru.

\section{Kepustakaan}

Bonwell, C.C., Active Learning: Creating Excitement In The Classroom, Center for Teaching and Learning: St. Louis College of Pharmacy, 1995.

Carrolina, Donna, Penerapan Strategi Active Learning Berbasis Web (Blended Learning) Dalam Upaya Menciptakan Pembelajaran Aktif Dan Pengaruhnya Terhadap Hasil Belajar, (Online) http://journal.unnes.ac.id/sju/index.php/ eeaj/article/view/559, diakses pada 29 April 2013.

Effendi, Mukhlison, Silabus Strategi Pembelajaran, PGMI, 2012. Hadi, Sutrisno, Metodologi Penelitian, Yogyakarta: Ardi Ofset, 1989.

Hartanto, Antonius \& Onno W. Purbo, E-Learning Berbasis PHP dan MySQL, Jakarta: Elex Media Komputindo, 2002. 
Horton, William \& Katherine Horton, E-Learning Tools and Technologies: A consumer Guide for Ttrainers, Teachers, Educators, and Instructional Designers, USA: Wiley Publishing, 2003.

Mahmudah, Umi, Active Learning dalam Pembelajaran Bahasa Arab, Malang: UIN-Malang Press, 2008.

Moleong, Lexy, Metodologi Penelitian Kualitatif, Bandung: Remaja Rosdakarya, 2006.

Munandar, Utami, Pengembangan Kreatifitas Anak Berbakat, Jakarta: Rineka Cipta, 2004.

Munir, Kurikulum Berbasis Teknologi Informasi dan Komunikasi, Bandung: Alfabeta, 2008.

Nasution, Metode Research, Jakarta: Bumi Aksara, 1996.

Nazir, Mohammad, Metode Penelitian, Jakarta: Ghalia Indonesia, 1988.

Ngalim Purwanto, Psikologi Pendidikan, Bandung: Remaja Rosdakarya, 2003.

Purwadarminta, Kamus Umum Bahasa Indonesia, Jakarta: Balai Pustaka, 1986.

Sanjaya, Wina, Pembelajaran dalam Implementasi Kurikulum Berbasis Kompetensi, Jakarta: Kencana, 2008.

Siahaan, Sudirman, E-Learning (Pembelajaran Elektronik) sebagai Salah Satu Alternatif Kegiatan Pembelajaran, Jurnal Pendidikan,(Online), 2002.

Silberman Mel, Active Learning 101 Strategis to Teach Any Subject,: YAPPENDES, 1996.

Slameto, Belajar dan Faktor-faktor yang Mempengaruhinya, Jakarta: Rineka Cipta, 2003.

Soekartawi, Prinsip Dasar E-Learning: Teori Dan Aplikasinya Di Indonesia, Jurnal Teknodik, Edisi No.12/VII/Oktober/2003, 2003.

Sopian, Ahmad, Peran Pendidik dalam Proses Belajar Mengajar Melalui Pengembangan e-Learning (Online)media.diknas.go.id/media/document/5084.pdf, diakses pada 29 April 2013.

Sriyono dkk, Teknik Belajar Mengajar Dalam CBSA, Jakarta: ineka Cipta, 1992.

Sudjana, Nana, Metode Statistika, Edisi Ke 6, Bandung: Tarsito, 1996. 
Sugandi A, dkk, Belajar dan Pembelajaran, Semarang: IKIP PRESS, 2000.

Tanti, Puput Dwi Maret, Penerapan Pembelajaran Aktif (Active Learning) Dengan Metode Mind Map Untuk Meningkatkan Kreativitas Belajar Biologi Siswa Kelas XI A3 SMA Negeri 1 Ngemplak Boyolali, Surakarta: FKIP Universitas Sebelas Maret, 2012.

Yasin, Fatah, Dimensi-dimensi Pendidikan Islam, Malang: UIN Malang Press, 2008.

Zaini, Hisyam dkk, Strategi Pembelajaran Aktif, Yogyakarta: CTSD IAIN Sunan Kalijaga, 2004.

(Online)http://edweb.sdsu.edu/people/bdodge/Active/ActiveLearni ng.html, diakses pada 29 April 2013. 


\title{
Ilmu Ladunni dalam Perspektif al-Ghazali
}

\author{
Agus Sutiyono \\ IAIN Walisongo Semarang \\ Email: aguszahroh@yahoo.com
}

\begin{abstract}
Science Ladunni inspiration is flowing light, which can occur after improvement (taswiyah). Rationally, all knowledge can be acquired through learning. This is key in pursuing the events and education trips. Learning becomes important when one wants to reach the succes top life in understanding the science. How to get the science ladunni according to al-Ghazali, namely; first, trying to grab all the knowledge and take the highest ration of science the most. Second, proper training (ar-riyad ash sad iqah) and supervision are valid (al-muraqabah as sahihah), and still a fraid God with truth. Third, thinking (tafakur), if the soul has learned and trained to be a science, then he bertafakur. Fourth rabbaniyah purify hearts decorated with zikrullah.
\end{abstract}

Keywords: al-Ghazali, Science ladunni.

\begin{abstract}
Abstrak
Ilmu Ladunni ialah mengalirnya cahaya ilham, yang bisa terjadi setelah penyempurnaan (taswiyah). Secara rasional, semua ilmu pengetahuan dapat diperoleh melalui belajar. Ini merupakan kunci dalam meniti peristiwa dan perjalanan pendidikan. Belajar menjadi penting Ketika seseorang ingin mencapai puncak keberhasilan hidupnya dalam memahami ilmu. Cara mendapatkan ilmu ladunni menurutt al-Ghazali yaitu; pertama, berusaha meraih semua ilmu dan mengambil jatah terbanyak dari ilmu yang paling banyak. Kedua, latihan yang benar (arriyadah as-sadiqah) dan pengawasan yang sahih (al-muraqabah as-sahihah), serta tetap merasa takut kepada Allah dengan sebenar-benarnya. Ketiga, berfikir (tafakur), apabila jiwa telah belajar dan terlatih akan suatu ilmu, kemudian ia bertafakur. Keempat mensucikan hati rabbaniyah yang dihiasi dengan żikrullah.
\end{abstract}

Kata kunci: al-Gazali, ilmu Ladunni. 


\section{A. Pendahuluan}

Manusia sebenarnya diciptakan oleh Tuhan sebagai makhluk yang sadar. Kesadaran manusia itu dapat disimpulkan dari kemampuannya berpikir, berkehendak dan merasa. Dengan pikirannya manusia mendapatkan (ilmu) pengetahuan. ${ }^{1}$ Menurut bahasa, kata ilmu adalah masdar yang maknanya sinonim dengan paham dan makrifat. Para ahli filsafat, mendefinisikan kata ilmu sebagai suatu gambaran yang dengan sifat itu orang yang mempunyainya akan menjadi jelaslah baginya sesuatu urusan. Menurut Abū Musāa al-Asy'ari, dikutip oleh Abdul Djalal, bahwa ilmu itu ialah sifat yang mewajibkan pemiliknya mampu membedakan dengan panca inderanya, sehingga tidak mungkin mengakibatkan berlawanan. ${ }^{2}$

Menurut al-Ghazali, ilmu adalah mengetahui sesuatu menurut apa adanya, dan Ilmu itu adalah sebagian dari sifat-sifat Allah. ${ }^{3}$ Al-Ghazali mengatakan dalam ar-risalah al-ladunniyah, bahwa ilmu adalah penggambaran jiwa yang berbicara (an-nafs annatiqah) dan jiwa yang tenang menghadapi hakikat berbagai hal. Seorang yang 'alim adalah samudera yang berpengetahuan dan memiliki penggambaran. Sedangkan objek ilmu adalah zat sesuatu yang ilmunya terukir dalam jiwa. ${ }^{4}$

Di dalam Islam, ilmu merupakan bagian yang integral bagi setiap pribadi manusia. Termasuk suatu kesempumaan iman seseorang apabila pelaksanaan suatu amal (perintah Allah) yang dikerjakan atas dasar ilmu. ${ }^{5}$ Dalam buku New Horizon in Muslim Education, Ali Aṣraf, dikutip oleh Noeng Muhadjir, memberikan evaluasi bahwa semua sains yang dilakukan Yunani dan Islam menggunakan pendekatan ontologis, sedangkan sains Barat menggunakan pendekatan manipulatif-manfaat.

Bangsa Barat sekarang ini lebih menekankan pada epistemologinya, menekankan pada prosedur kerja ilmiahnya. Bahwa keruntutan prosedur kerja ilmiah menentukan kebenaran yang

\footnotetext{
${ }^{1}$ Soerjono Soekanto, Sosiologi Suatu Pengantar, (Jakarta: Raja Grafindo Persada, 1999), hlm. 5

${ }^{2}$ Abdul Djalal, Ulumul Qurān, (Surabaya: Dunia Ilmu, 2000), hlm. 2.

${ }^{3}$ Al-Ghazali, Ihyā Ulūmuddìn, Juz I, (Semarang: Toha Putra, T.t.), hlm. 29.

${ }^{4}$ Al-Ghazali, Ar-Risalah al-Ladunniyyah, (Terj.) (Yogyakarta: Mitra Pustaka, 2004), hlm. 9.

${ }^{5}$ M. Bahri Ghazali, Konsep Ilmu Menurut al-Ghazali Suatu Tinjauan Psikologik Pedagogik, (Jakarta: Pedoman Ilmu Jaya, 1996), hlm. 96.
} 
dicapai. Ditinjau dari filsafat ilmu, pendekatan dominan Yunani adalah pendekatan ontologis. Islam dalam pengaruh Yunani juga menampilkan telaah substansialistik tentang ide-ide pemahamannya intuitif. Makna dibentuk berdasar keyakinan teologis dan metafisik. Sedangkan tentang IPTEK Barat ditinjau dari segi filsafat ilmu, menekankan pada pendekatan epistemologis, makna dicari lewat hubungan kausal. Makna dibentuk lewat penalaran, lewat discourse. Menurutnya, dikutip Noeng Muhadjir, bahwa orientasi IPTEK Islam diberangkatkan dari moral al- Quran, konsep IPTEK didasarkan pada ketentuan mutlak yang ditetapkan dalam al-Qur'an dan as-sunnah. IPTEK Islam bukan hanya mencari kebenaran, melainkan juga mencari kebijakan dan rida Allah. Bila demikian, maka pendekatan dominan dalam IPTEK Islam, sesuai Semangat al-Qur'an, adalah aksiologis. $^{6}$

\section{B. Pembahasan}

Dalam memahami ilmu, al-Ghazali mendasarkan pemikirannya pada ajaran-ajaran agama (Islam). Oleh karena itu sebagian ahli mengatakan bahwa epistemologi al-Ghazali adalah epistemologi Islam ${ }^{7}$. Al-Ghazali menjelaskan bahwa Ilmu itu menghidupkan hati dari kebutaan, sinar penglihatan dari kegelapan dan kekuatan badan dari kelemahan yang menyampaikan hamba ke kedudukan orang-orang yang baik dan derajat yang tinggi. Memikirkan tentang ilmu itu mengimbangi puasa, mempelajarinya mengimbangi mendirikan malam, dengan ilmu Allah swt., ditaati, dengannya Dia ditauhidkan, dimuliakan, dengannya hamba menjadi wara dengannya sanak kerabat disambung, dengannya diketahui halal dan haram. Ilmu itu pemimpin sedangkan amal adalah pengikutnya orang-orang yang berbahagia itu diberi ilham mengenai ilmu dan orang-orang yang celaka itu terhalang. ${ }^{8}$

Al-Ghazali juga menerangkan bahwa ilmu itu adalah keutamaan pada Dzat-Nya secara mutlak tanpa dibandingkan, karena ilmu itu adalah sifat kesempurnaan Allah yang maha suci. ${ }^{9}$ AlGhazali Ketika membahas ilmu lebih tampak menggambarkan ta-

${ }^{6}$ Noeng Muhadjir, Filsafat Ilmu Positivisme, PostPositivisme, dan Post Modemisme, (Yogyakarta: Rakesarasin, 2001), hlm. 66-67.

${ }^{7}$ Muhadjir, Filsafat Ilmu Positivisme ..., hlm. 72.

${ }^{8}$ Al-Ghazali, Ihyā Ulümuddìn, hlm. 12-13.

${ }^{9}$ Al-Ghazali, Ihyyā Ulümuddìn, hlm. 132. 
tanan sosial masyarakat, dalam Pengertian bahwa suatu ilmu atau profesi tertentu diperlukan untuk melaksanakan kegiatan-kegiatan yang diwajibkan dalam tatanan tersebut. ${ }^{10}$ Untuk lebih jelasnya ilmu menurut al-Ghazali dapat diklasifikasikan sebagai berikut:

1. Secara Epistemologis

Secara epistemologis, ilmu terbagi menjadi dua: syari'ah dan ghairu syari'ah. Ilmu syariah ialah ilmu yang diperoleh dari para Nabi dan tidak ditunjukkan oleh akal manusia kepadanya. ${ }^{11}$ Menurut al-Ghazali, ilmu-ilmu itu seluruhnya terpuji. Ilmu itu mempunyai pokok-pokok, cabang-cabang, pendahuluan-pendahuluan dan penyempurna-penyempurna, yaitu:

a. Pokok-pokoknya itu ada empat, yaitu: Kitabullah, Sunnah rasul-Nya, ijma' ummat dan atsarsahabat. Ijma' itu pokok dari segi bahwa itu menunjuk atas sunnah. Ijma' adalah pokok dalam tingkatan ketiga. Demikian juga atsar, maka itu juga menunjuk atas sunnah karena para sahabat itu menyaksikan wahyu dan penurunannya, mereka dengan karinah-karinah keadaan dapat mengetahui apa yang gaib (tidak diketahui) oleh selain mereka. Barangkali kalimat tersebut tidak cukup untuk mengungkapkan apa yang diketahui dengan karinah-karinah.

b. Cabang (furu') yaitu sesuatu yang difahami dari pokokpokok ini, bukan dengan kepastian lafal-lafalnya tetapi dengan Pengertian-Pengertian yang diketahui oleh akal. Oleh sebab itu meluaslah pemahaman itu sehingga dari lafal itu difahami oleh apa yang dilafalkan oleh lainnya. Ini terbagi menjadi dua macam, yaitu:

Pertama, berkaitan dengan kemaslahatan-kemaslahatan dunia dan itu termuat dalam kitab fikih dan yang bertanggung jawab adalah para fuqaha. Mereka itulah ulama dunia. Kedua, sesuatu yang berkaitan dengan kemaslahatan-kemaslahatan akhirat. Yaitu ilmu mengenai keadaan hati dan akhlak yang terpuji dan tercela, sesuatu yang diridhai di sisi Allah Ta'ala dan sesuatu yang dibenciNya.

.${ }^{10}$ Abidin Ibnu Rusn, Pemikiran al-Ghazali Tentang Pendidikan, (Yogyakarta: Pustaka Pelajar, 1998), hlm. 44.

${ }^{11}$ Rusn, Pemikiran al-Ghazali ..., hlm. 44. 
Ketiga, muqaddimah yaitu ilmu-ilmu yang berlaku sebagai alat seperti ilmu bahasa dan tata bahasa karena keduanya itu merupakan alat bagi ilmu (al-Qur'an) dan sunnah Nabi saw. Bahasa dan tata bahasa itu bukanlah termasuk ke dalam golongan ilmu-ilmu sari'at itu sendiri, tetapi mendalami keduanya disebabkan syara' karena syari'at ini datang dengan bahasa Arab. Setiap syari'at tidak jelas kecuali dengan bahasa, maka menjadilah bahasa itu sebagai alat.

c. Penyempurna-penyempurna, yaitu mengenai ilmu alQur'an. Terbagi kepadasesuatu yang berkaitan dengan lafal seperti belajar qira'at (bacaan al-Qur'an) dan makhrajmakhraj huruf, kepada sesuatu yang berkaitan dengan makna seperti tafsir, karena bersandarnya juga kepada naql, karena bahasa semata tidak dapat berdiri sendiri. Kepada sesuatu yang berkaitan dengan hukum-hukumnya seperti mengetahui nasikh dan mansukh, 'am dan khas, nas dan zahir, dan cara mempergunakan sebagian dengan sebagian yang lain, itulah ilmu yang disebut usul fiqh, dan juga menggarap sunnah.

Adapun penyempurna dalam atsar dan hadis maka ilmu mengenai rijal al-hadits (periwayat hadis), nama dan nasab (keturunan) mereka, nama sahabat dan sifat-sifat mereka, mengetahui keadilan rawi dan keadaan mereka untuk membedakan yang lemah dari yang kuat, dan mengetahui umur mereka untuk membedakan mursal dari musnad. Demikian juga sesuatu yang berkaitan dengannya. ${ }^{12}$ Adapun ilmu gairu syar'iyahatau ilmu aqliyah adalah ilmu yang bersumber dari akal, baik yang diperoleh secara darurimaupun ihtisab. Duluri ialah yang diperoleh dari insting akal itu sendiri tanpa melalui taklid atau indera, dari mana dan bagaimana datangnya manusia tidak mengetahuinya. Sedangkan ịtisab ialah mencari faidah ilmu melalui kegiatan belajar dan mencari argumenargumen.

\footnotetext{
${ }^{12}$ Al-Ghazali, Ihyyā Ulūmuddìn, hlm. 17-18.
} 


\section{Secara Ontologis}

Berhubungan dengan tugas dan tujuan hidup manusia, alGhazali menguraikan ilmu melalui pendekatan ontologis, membicarakan sifat-sifat dasar dan aneka ragam ilmu itu sendiri. ${ }^{13}$ Secara ontologis, al-Ghazali membagi ilmu menjadi dua macam:

a. Ilmu fardu 'ain, yakni ilmu yang dibutuhkan untuk melaksanakan tugas-tugas akhirat dengan baik. Ilmu ini terdiri atas: ilmu tauhid, ilmu syari'at dan ilmu sirri. Menurut alGhazali ilmu fardu 'ain,yaitu ilmu tentang cara-cara melaksanakan amal yang wajib. Barang siapa yang telah mengetahui perbuatan yang wajib beserta waktu untuk mengerjakannya, berarti ia telah mengetahui ilmu yang termasuk ke dalam jenis fardu 'ain. ${ }^{14}$ Manusia berbeda pendapat yang menjadi fardu atas setiap muslim. Mereka berkelompok-kelompok menjadi lebih dari pada dua puluh golongan. Setiap golongan menempatkan wajib atas ilmu yang menjadi kecenderungannya.

b. Ilmu farḍu kifayah, yakni ilmu-ilmu yang berkaitan dengan urusan keduniaan, yang perlu diketahui manusia. Ilmu-ilmu ini berhubungan dengan profesi manusia, oleh karena itu tidak setiap manusia dituntut memiliki semua jenis yang ada, tetapi cukup dikembangkan melalui orangorang tertentu yang telah memiliki kemampuankemampuan khusus untuk mewujudkan kehidupan dunia ini. ${ }^{15}$ Menurut al-Ghazali fardu kifayahialah setiap ilmu yang tidak dapat tidak dibutuhkan dalam menegakkan urusan-urusan dunia seperti kedokteran karena kedokteran itu suatu kepastian (daruri) dalam kebutuhan menjaga kekalnya tubuh. Seperti berhitung karena itu pasti dibutuhkan dalam pergaulan, membagi wasiat, warisan dan Iain-lain. Inilah ilmu-ilmu yang seandainya suatu negeri tidak ada orang yang menegakkannya maka penduduk negeri itu berdosa. Apabila seorang menegakkannya maka cukuplah dan gugurlah farḍu kifayahitu.

\footnotetext{
${ }^{13}$ Rusn, Pemikiran al-Ghazali ..., hlm. 46.

${ }^{14}$ Al-Ghazali, Ihyā Ulümuddìn, hlm. 16.

${ }^{15}$ Rusn, Pemikiran al-Ghazali ..., hlm. 47.
} 
3. Secara Aksiologis

Selanjutnya al-Ghazali menggunakan pendekatan aksiologis dalam menilai jenis ilmu. ${ }^{16}$ Ilmu-ilmu syari'ah bersifat terpuji secara keseluruhan. Sedangkan ilmu gairu syar'iyah, ada yang terpuji, ada yang tercela, dan ada pula yang mubah. Artinya, dalam keadaan tertentu terpuji, tetapi dalam keadaan yang lain tercela atau mubah. Al-Ghazali mengatakan, bahwa ilmu itu sendiri tidaklah tercela. Ilmu itu tercela dalam hak hamba, karena salah satu dari tiga buah sebab, yaitu: Pertama, ilmu itu menyampaikan kepada kemadharatan (bahaya). Adakalanya bagi pemiliknya atau orang-orang lain seperti tercelanya ilmu sihir dan tenung. Kedua, Ilmu itu adalah membahayakan pemiliknya pada umumnya seperti ilmu nujum ${ }^{17}$. Ketiga, terjun ke dalam ilmu tidak memberi faedah kepada orang itu sendiri dari ilmunya. Ilmu semacam ini tercela bagi orang itu. Seperti dipelajarinya ilmu yang tidak jelas sebelum mempelajari ilmu yang lebih penting dan lebih jelas, menggali ilmu yang serba rahasia sebelum mempelajari ilmu yang telah teruji dan menelaah rahasia ketuhanan. ${ }^{18}$

Al-Ghazali meletakkan suatu pemahamannya tentang hakikat ilmu dalam bentuk kesatuan teoritik, yakni menjurus pada pemahaman ilmu sebagai ilmu Allah yang harus dituntut dan dikaji oleh setiap pribadi dalam upaya membawa dunia dan seisinya ke gerbang kemaslahatan. ${ }^{19}$ Menurut al-Ghazali, ilmu adalah pangkal dari segala perbuatan, oleh sebab itu maka ilmu dan ibadah adalah dua mata rantai yang saling berkait, karena pada dasarnya segala yang kamu lihat, kamu dengar dari beberapa karangan, dari pengajaran guru, dan dari hasil perenungan adalah untuk ilmu dan ibadah..$^{20}$

Al-Ghazali juga mengakui keberadaan (eksistensi) indra dan akal, akan tetapi kedua instrumen insaniyah itu sangat terbatas daya capainya dan tidak mampu menjelaskan kebenaran itu secara hakiki. Bagi al-Ghazali kebenaran itu bukan hanya terbatas pada kebenaran indrawi (konkret), tetapi

\footnotetext{
${ }^{16}$ Rusn, Pemikiran al-Ghazali ..., hlm. 48.

${ }^{17}$ Al-Ghazali, Ihyā Ulūmuddìn, hlm. 29.

${ }^{18}$ Al-Ghazali, Ihyā Ulūmuddìn, hlm. 31.

${ }^{19}$ Ghazali, Konsep Ilmu ..., hlm. 75.

${ }^{20}$ Al-Ghazali, Manhaj al-'Abidin, (Semarang: Toha Putra, T.t.), hlm. 6.
} 
dibalik kebenaran yang nyata itu terselip suatu kebenaran abstrak yang nyata pula adanya.

Kebenaran konkret adalah kebenaran yang dapat dipantau melalui pancaindra, dapat dilihat, dirasa, didengar bahkan juga dicerna dengan akal pikiran. Kebenaran itu disebutnya kebenaran (pengetahuan) mu'amalah'. Kebenaran abstrak berada di alam ide, transendent dan nyata adanya, ia disebut pengetahuan "mukasyafah". Pengetahuan ini sulit ditembus dengan kata-kata, tidak dapat diungkapkan dengan pembicaraan, tidak mampu inderawi menjamahnya dan tidak kuasa akal meluluskannya.

Al-Qur'an dan hadis adalah jalan (tariqoh) untuk memahaminya. Karena mukasyafah merupakan kebenaran yang bersifat vertikal, dari langit dan bermuara langsung pada Allah. ${ }^{21}$ Dengan demikian ilmu itu hanya mampu dibuka dengan kunci dan jalan yang dibentangkan oleh Allah untuk sampai kepada tingkat mukasyafah itu. Di wilayah mukasyafah terletak kepercayaan, sebab kepercayaan tidaklah semata-mata berdasarkan penelitian, melainkan umumnya terjadi karena bisikan, kekuatan hati yang datangnya bukan dari manusia tetapi ia berasal dari kekuatan maha pencipta dalam bentuk 'ilham'. Ilham merupakan pengetahuan yang diperoleh dalam kebangkitan, ia merupakan pengungkapan kepada manusia pribadi yang disampaikan kepadanya oleh Allah pemilik ilmu itu melalui batinnya. ${ }^{22}$

Imam al-Ghazali menyatakan, dikutip A. Busyairi Harits, bahwa ilmu yang dihasilkan melalui ilham dinamakan ilmu Ladunni. ${ }^{23}$ Ilmu Ladunni menurutnya ialah mengalirnya cahaya ilham, terjadi setelah taswiyah (penyempurnaan). ${ }^{24}$ Ilmu itu memiliki tingkatan-tingkatan yang berbeda akibat perbedaan tingkatan manusia. Ilmu paling tinggi adalah ilmu yang muncul dari wahyu langit atau ilmu ladunni pada keadaan dekat dengan Allah. ${ }^{25}$

${ }^{21}$ Ghazali, Konsep Ilmu..., hlm. 72-73.

${ }^{22}$ Ghazali, Konsep Ilmu ..., hlm. 73.

${ }^{23}$ Busyairi Harits, Ilmu Ladunni dalam Perspektif Teori Belajar Modern, (Yogyakarta: Pustaka Pelajar, 2004), hlm. 2.

${ }^{24}$ Al-Ghazali, ar-Risalah al-Ladunniyyah, hlm. 93.

${ }^{25}$ Fu'ad Farid Isma'il dan Abdul Hamid Mutawalli, Mabādi al-Falșafah wa al-Akhlaq, (Terj.) (Yogyakarta: Ircisod, 2003), hlm. 252. 


\section{Ilmu Ladunni dalam Pandangan al-Ghazali}

Menurut al-Ghazali, ilmu ladunni adalah mengalirnya cahaya ilham, terjadi setelah taswiyah (penyempurnaan). ${ }^{26}$ Untuk mendapatkan ilmu ladunni harus melalui beberapa proses sebelum sampai pada tingkat penyempurnaan. Imam al-Ghazali menggolongkan ilmu Ladunni termasuk pengajaran bersifat ketuhanan. Ia membagi dua jalan pengajaran, yaitu pemberian pelajaran melalui wahyu dan pemberian melalui ilham. Pemberian pelajaran melalui wahyu terjadi apabila hati sudah sempurna DzatNya, maka hilang tabiat yang kotor, ketamakan dan angan-angan yang sesat. Jiwa selalu menghadapkan wajahnya kepada Sang Pencipta yang menumbuhkannya. Ilmu ini biasanya diterima nabi.

Adapun pembelajaran melalui ilham adalah peringatan jiwa kulliyah (total) kepada jiwa manusia secara juz'(sebagian), yang bersifat kemanusiaan sesuai dengan kadar kesiapan dan kekuatan penerimanya. Ilham sendiri adalah bekas wahyu. Wahyu adalah penjelasan perkara gaib, sedangkan ilham adalah bentuk samarnya. Ilmu yang diperoleh dari wahyu dinamakan ilmu nabawy, sedangkan ilmu yang diperoleh dari ilham dinamakan ilmu Ladunni.

Ilmu Ladunni adalah ilmu yang pencapaiannya tanpa perantara antara jiwa seseorang dengan Allah. Ia seperti cahaya dari lampu gaib yang jatuh ke dalam hati yang bening, bersih dan halus. Proses munculnya ilham melalui penuangan akal kully dan dari penyinaran jiwa kulliyyah. Karena itu wahyu merupakan perhiasan para nabi sedangkan ilham merupakan perhiasan para wali (kekasih Allah). ${ }^{27}$ Apabila pintu pikiran telah terbuka atas jiwa, seseorang akan mengerti bagaimana cara berpikir dan bagaimana kembali dengan ketajaman pikirannya kepada orang yang dicari. Hati menjadi lapang, mata hati menjadi terbuka, kemudian keluarlah apa yang ada di dalam hati berupa kekuatan sampai perbuatan dengan tanpa tambahan pencarian dan kesulitan.

Puncaknya, dapat dijelaskan bahwa hakikat ilmu ladunni adalah perjalanan cahaya ilham setelah kesempurnaan jiwa. Hal ini dapat dirujukkan pada tiga jalur penting. Sebagai proses untuk mencapai ilmu Ladunni, yaitu:

\footnotetext{
${ }^{26}$ Isma'il dan Mutawalli, Mabādi al-Falsafah ..., hlm. 93.

${ }^{27}$ Isma'il dan Mutawalli, Mabādi al-Falșafah ..., hlm. 38.
} 
1. Meraih semua ilmu, dan mengambil jatah terbanyak dari ilmu yang paling banyak. $^{28}$ Ini berarti bahwa al-Ghazali tidak menafikan adanya proses pembelajaran pada diri manusia, untuk meraih ilmu Ladunni. Tangga pertama yang harus dilalui oleh seorang yang ingin mendapatkannya adalah dengan mengoptimalkan potensi yang ada dalam diri manusia tersebut yaitu potensi akal yang diwujudkan dalam proses pembelajaran. Ladunni adalah bukan berarti meniadakan belajar, tetapi tidak melalui sebab yang biasa dilakukan manusia dengan jenjang dan tahapan belajar dalam waktu tertentu, seperti sekolah mulai dari tingkat paling rendah sampai tingkat perguruan tinggi.

2. Latihan yang benar (ar-riyadah as-sadiqah) dan pengawasan yang sahih (al-muraqabah as-sahihah), serta tetap merasa takut kepada Allah dengan sebenar-benarnya, sebagaimana yang diisyaratkan nabi dalam sabdanya: "Barangsiapa mengamalkan ilmu yang telah diketahui, Allah akan mewariskan kepadanya ilmu yang belum ia ketahui". Ilmu identik dengan belajar, tanpa melalui proses belajar maka mustahil akan ada ilmu pengetahuan, proses belajar yang dijalankan berlangsung melalui perangkat lahir batin, fisik dan spiritual. Keduanya saling mempengaruhi dan membutuhkan perhatian yang seimbang. Dalam tahapan kedua inilah seseorang dituntut untuk latihan yang benar, maksudnya, setiap ilmu yang telah dipelajarinya dipraktikkan dalam kehidupan sehari-hari atau dengan kata lain ilmu yang telah dipelajarinya kemudian diamalkan dengan benar, sehingga ia akan memperoleh pengalaman baru hasil dari pengalamannya.

3. Tafakur (berfikir), apabila jiwa telah belajar dan terlatih akan suatu ilmu, kemudian ia bertafakur tentang gejala-gejalanya dengan sarat pemikirannya dapat membuka pintu gaib, dia seperti saudagar yang mengelola harta kekayaannya dengan syarat pengelolaan tersebut dapat membuka pintu keuntungan. Jika seorang saudagar salah jalan, ia akan terjerumus ke dalam jurang kerugian. Seorang pemikir yang menempuh jalan yang benar, akan termasuk golongan żawi al-albāb (orang-orang yang berakal). Dengan begitu, rahasia alam gaib akan jelas dipertampakkan dalam hatinya. Ia akan menjadi seorang 'alim dan seorang pemikir penerima ilham. ${ }^{29}$

\footnotetext{
${ }^{28}$ Isma'il dan Mutawalli, Mabādi al-Falșafah ..., hlm. 94.

${ }^{29}$ Isma'il dan Mutawalli, Mabādi al-Faḷafah..., hlm. 95-95.
} 
Ilmu pengetahuan dibangun dalam pikiran. Setiap individu membangun sendiri pengetahuannya. Kecerdasan akal atau intelegensi merupakan puncak tertinggi setelah seseorang memiliki kualitas. Proses belajar dengan menggunakan pendekatan teori, percobaan, latihan dan penelitian tetap dilakukan meski pada sisi lain mengakui adanya campur tangan Tuhan terhadap manusia. kecerdasan yang diperoleh tetap dibangun di atas rutinitas belajar dengan bersungguh-sungguh dan usaha penuh kepasrahan atas kehendak Allah. Adapun cara mensucikan perbuatan-perbuatan tercela dalam rangka membersihkan jiwa, dapat ditempuh dengan empat jalan, yaitu: (1) Mensucikan diri dari najis dan hadas, (2) Mensucikan diri dari dosa lahir (maksiat) yang dilakukan panca indera, (3) Suci dari dosa batin, (4) Mensucikan hati Rabbaniyah.

\section{Penutup}

Ilmu ladunni ialah mengalirnya cahaya ilham, yang bisa terjadi setelah penyempurnaan (taswiyah). Seluruh jiwa-jiwa insani memungkinkan bagi semua ilmu.Jiwa itu mampu menampung seluruh ilmu tanpa harus ada yang ditolak, berdesakan, merasa jemu, dan menghilang. Secara rasional, semua ilmu pengetahuan dapat diperoleh melalui belajar. Ini merupakan kunci dalam meniti peristiwa dan perjalanan pendidikan. Belajar menjadi penting Ketika seseorang ingin mencapai puncak keberhasilan hidupnya dalam memahami ilmu. Proses pembelajaran yang dijalankan seseorang berlangsung melalui perangkat lahir, batin, fisik dan spiritual.

Cara mendapatkan ilmu Ladunni menurutt al-Ghazali yaitu; pertama, berusaha meraih semua ilmu dan mengambil jatah terbanyak dari ilmu yang paling banyak. Ini berarti bahwa alGhazali tidak menafikan adanya proses pembelajaran pada diri manusia, untuk meraih ilmu Ladunni. Sebab itu Ladunni adalah bukan berarti meniadakan belajar. Kedua, latihan yang benar (arriyaḍah ass-sadiqah) dan pengawasan yang sahih (al-muraqabah assahihah), serta tetap merasa takut kepada Allah dengan sebenarbenarnya Ketiga, berfikir (tafakur), apabila jiwa telah belajar dan terlatih akan suatu ilmu, kemudian ia bertafakur. Keempat mensucikan hati rabbaniyah yang dihiasi dengan żikrullah.

\section{Kepustakaan}


Abed al-Jabiri, Muhammad, Al-Kasyfu 'An Manahij al-Adillah Fi Aqa'id al-Millah, terj. Oleh Aksin Wijaya, Yogyakarta: Ircisod, 2003.

al-Qurtubi, Abi Abdillah Muhammad ibn Ahmad al-Anshari, alJami' Li ahkami al-Qurān, Beirut Libanon: Dar al-Fikri, 1994.

Al-Ghazali, Ar-Risalah al-Ladunniyah, "Terj. Oleh" Khalifurrahman Fatf, Yogyakarta: Mitra Pustaka,Dunya, Sulaiman, 2002. Al Ilaqiqatu fi Nazhari al-Ghazali, Terj. Oleh Ibnu Ali, Surabaya: Pustaka Hikmah Pcrdana, 2004.

Bakker, Anton, Metode-metode Filsafat, Jakarta: Ghalia Indonesia, 1986.

Djalal, Abdul, Ulümul Qữan, Surabaya: Dunia Ilmu, 2000.

Departemem Agama Republik Indonesia, 1994. al-Qurān dan Terjemahannya, Semarang: Kumudasmoro Grafindo,

Fu'ad Farid Isma'il dan Abdul Hamid Mutawalli, Mabadi al-Falsafah wa al-Akhlaq, Ibnu Rusn, Abidin, Pemikiran al-Ghazali Tentang Pendidikan, Yogyakarta: Pustaka Pelajar, 1998.

Ghazali, M. Bahri, Konsep Ilmu Menurut al-Ghazali Suatu Tinjauan Psikologik Pedagogik, Jakarta: Pedoman Ilmu Jaya, 1996.

Harits, A. Busyairi, Ilmu Ladunni dalam Perspektif Teori Belajar Modern, Yogyakarta: Pustaka Pelajar, 2004.

Mustansyir, Rizal dan Misnal Munir, Filsafat Ilmu, Yogyakarta: Pustaka Pelajar, 2004.

Muhajir, Noeng, Metodologi penelitian Kualitatif, Edisi IV, Yogyakarta: Rake Sarasin, 2002.

----, Filsafat Ilmu Positivisme, Postpositivisme, dan Postmodernisme, Yogyakarta: Rakesarasin. Smith, Margareth. 2000. Al-Ghazali the Mistic, Terj. Oleh Amrouni, Jakarta: Riora Cipta, 2001.

Shihab, Quraish, WawasanAt-Quran :Tafsir Maudlui Atas Pelbagai Persoalan Umat,Bandung: Mizan, 1999.

Soekanto, Soerjono, Sosiologi Suatu Pengantar, Jakarta: Raja Grafindo Persada, 1999.

Syadali, Ahmad dan Mudzakir, Filsafat Umum, Bandung: Pustaka Setia, 2004.

Walgito, Bimo, Pengantar Psikologi Umum, Yogyakarta: Yayasan Penerbitan Fakultas Psikologi UGM, 1986. 


\title{
Antisipasi Degradasi Moral di Era Global
}

\author{
Sofa Muthohar \\ IAIN Walisongo Semarang \\ Email: sofamuthohar@yahoo.co.id
}

\begin{abstract}
In the globalization era, environment has a broad definition. Someone could very easily find an atmosphere that he likes. It brings to positive or negative effects. Teenagers (aged 12-22 years) are the generation most vulnerable to the negative influences that lead to moral decadence. This problem is very difficult to overcome if it just rely on the secular West psychological theories. Islamic education is expected to provide a solution to these problems through functional strategy, integral and progressive. Religious teachings not only memorized but should also be presented in the spirit to assist young people in solving the problem. This strategy could be: guiding problem solving in dealing with problems themselves and society as well as the formation of an integral understanding of his relationship with God. Teens should have spirit that can transform itself into a superior person.
\end{abstract}

Keywords: moral degradation, teens, globalization, progressive Islamic education integral functional.

\begin{abstract}
Abstrak
Dalam era globalisasi, lingkungan memiliki definisi yang luas. Seseorang bisa sangat mudah menemukan suasana yang dia suka sehingga memunculkan efek positif atau negatif. Remaja merupakan generasi yang paling rentan terhadap pengaruh negatif yang menyebabkan dekadensi moral. Masalah ini sangat sulit diatasi jika hanya mengandalkan teori-teori psikologi Barat yang sekuler. Pendidikan Islam diharapkan mampu memberikan solusi masalah ini melalui strategi yang fungsional, integral dan progresif. Ajaran agama tidak hanya dihafal tetapi juga harus dihadirkan dalam jiwa untuk mendampingi kaum muda dalam menyelesaikan masalahnya. Strategi ini bisa berupa: pembimbingan problem solving dalam menghadapi persoalan diri dan masyarakatnya serta pembentukan pemahaman secara integral tentang hubungannya dengan Allah. Remaja harus memiliki mental yang dapat merubah dirinya menjadi pribadi yang unggul.
\end{abstract}

Kata kunci: Degradasi moral, remaja, globalisasi, pendidikan Islam fungsional, integral, dan progresif. 


\section{A. Pendahuluan}

Moralitas sebagai bentuk kesepakatan masyarakat mengenai apa yang layak dan apa yang tidak layak dilakukan, mempunyai sistem hukum sendiri. Hampir semua lapisan masyarakat mempunyai suatu tatanan masing-masing, bahkan komunitas terkecil masyarakat kadang mempunyai moral/etika tersendiri dengan sistemnya sendiri. Tidak jarang hukuman bagi mereka yang melanggar moralitas, lebih kejam daripada hukuman yang dijatuhkan oleh institusi formal. Hukuman terberat dari seorang yang melanggar moralitas adalah beban psikologis yang terus menghantui, pengucilan dan pembatasan dari kehidupan yang 'normal'.

Masing-masing masyarakat mempunyai istilah yang beragam dalam membahasakan moral ini, ada yang menyebutnya dengan etika dan dalam Islam dikenal dengan akhlak. Dalam komunitas profesional dikenal dengan kode etik, sedangkan di tengah masyarakat sering dibahasakan dengan sopan santun, keseluruhannya mempunyai kesamaan yaitu apa yang patut dan apa yang tidak patut dilakukan oleh anggotanya.

Di tengah arus globalisasi, lingkungan pendidikan remaja,kini tidak lagi monoton dan terbatas di dalam lingkungan sekolah atau lembaga pendidikan. Anak bisa jadi berada di dalam lingkungan sekolah, namun kini dia punya akses untuk berhubungan, melihat langsung dan bisa jadi terlibat dalam kehidupan lain di dunia lain dengan media teknologi dan informasi. Kini lingkungan pendidikan mempunyai definisi yang lebih luas yaitu bukan hanya di mana siswa/anak itu tinggal, namun mencakup juga di mana anak itu menemukan dirinya sebagai seorang yang berarti. Anak dengan mudahnya menemukan tempat, suasana dan lingkungan yang berbeda dan kemudian mengidentifikasi menjadi suatu keadaan yang cocok atau tidak cocok untuk dirinya.

Dengan berbagai pengaruh lingkungan yang berbeda-beda ini, membuka peluang yang sangat lebar bagi seorang remaja untuk mempunyai kepribadian ganda (split personality) karena terjadinya gangguan pada masa remaja (childhood disorder)yang kalau dibiarkan terus-menerus dapat berakibat pada kejahatan remaja (juvenile delinquency). ${ }^{1}$

${ }^{1}$ Kartini Kartono, Patologi Sosial 2, Kenakalan Remaja, (Jakarta: Raja Grafindo Persada, 2013), hlm. 3-5. 
Di tengah keterbukaan inilah pentingnya penguatan kepribadian yang bermoral pada diri anak berbasis agama, karena sekarang ini moralitas yang dipilih juga akan mempengaruhi kekuatan pengaruhnya pada diri seseorang, yang dapat berakibat pada kekuatan prinsip dirinya untuk bisa memilih dan memilah serta memutuskan yang baik dan tidak baik, yang pantas dan yang tidak pantas bagi dirinya. Jangan sampai terjadi, merasa sudah membekali moralitas pada remaja, namun keliru dengan moralitas yang hampa karena ditegakkan dari nilai-nilai spiritual. Di sinilah peran penting pendidikan agama Islam yang integral dan fungsional dalam mengantisipasi degradasi moral remaja di era global.

\section{B. Labilitas Kepribadian Remaja}

Remaja (adolescence) berlangsung antara usia 12-21 tahun bagi wanita dan 13-22 tahun bagi laki-laki, ${ }^{2}$ menjadi satu generasi yang paling rawan terhadap pengaruh negatif, walaupun sangat berpotensi untuk bisa diarahkan kepada hal yang positif karena ditinjau dari sisi fisik dan psikisnya(psikopisik) sedang dalam tahap perubahan yang sangat menonjol dari anak-anak menuju dewasa. ${ }^{3}$ Para pakar psikologi rata-rata memandang masa remaja sebagai masa yang penting yang sangat mempengaruhi perjalanan hidup seseorang.

Sigmund Freud misalnya memandang masa remaja sebagai masa mencari hidup seksual yang mempunyai bentuk definitif; Spranger menyebutnya sebagai suatu masa pertumbuhan dengan perubahan struktur kejiwaan yang fundamental tentang kesadaran akan 'aku' yang berpengaruh terhadap berbagai segi kehidupan; Hoffman memandang masa remaja sebagai masa pembentukan

\footnotetext{
${ }^{2}$ Kalau dibagi antara remaja awal dengan dengan remaja akhir batasnya adalah usia 17/18 tahun, Lihat Muhammad Al-Mighwar, Psikologi Remaja, Petunjuk Bagi Guru dan Orang Tua, (Bandung: Pustaka Sia, 2011), hlm. 62. Maka usia 17 tahun sering menjadi tonggak dan ukuan seseorang remaja dianggap mulai memasuki masa kedewasaan karena masuk periode remaja akhir dengan mulainya penataan pola pikir dan mulai dianggap siap untuk mengemban beban-beban sosial orang dewasa. http://aurabianglala.blogspot.com/2012/12/periode-emas-dan-kritis-pada-anak.html, diakses $\operatorname{tgl} 17 / 10 / 2013$.

${ }^{3}$ Achmad Juntika Nurihsan dan Mubiar Agustin, Dinamika Perkembangan Anak \& Remaja, Tinjauan Psikologi, Pendidikan, dan Bimbingan, (Bandung: Refika Aditama, 2013), hlm.68.
} 
sikap-sikap terhadap segala sesuatu yang dialami individu; sedangkan Conger dan Erikson menyebut masa remaja sebagai masa yang amat kritis yang mungkin dapat menjadi the best of time and the worst of time. Kalau seorang remaja mampu mengatasi berbagai tuntutan secara integratif maka ia akan menemukan identitasnya yang akan dibawa menjelang masa dewasanya, namun sebaliknya jika ia gagal, maka ia akan berada pada krisis identitas (identity crisis) yang berkepanjangan. ${ }^{4}$

Secara tradisional, masa remaja dianggap sebagai periode badai dan tekanan (strum and drang atau storm and stress), suatu masa yang ditandai dengan ketegangan emosi yang tinggi secara internal sebagai akibat dari perubahan fisik dan kelenjar yang secara eksternal karena adanya tekanan sosial dalam menghadapi kondisi lingkungan yang baru akibat dari kurang mempersiapkan diri dalam menghadapi keadaan dan lingkungan baru tersebut. Tidak semua orang menghadapi badai dan tekanan dalam masa remajanya namun mayoritas menghadapinya dengan ketidakstabilan emosi dalam usahanya menyesuaikan diri dengan pola prilaku baru dan harapan sosial yang baru. ${ }^{5}$

Suatu hal yang harus diwaspadai khususnya pada masa remaja awal yaitu adanya perasaan ambivalensi antara keinginan bebas dari dominasi pengaruh orang tua sekaligus kebutuhan bimbingan dan bantuan dari orang tuanya. ${ }^{6} \mathrm{Hal}$ ini muncul akibat dari adanya keharusan dalam diri remaja untuk menyesuaikan diri sosial terutama dengan lawan jenis dan menyesuaikan diri dengan orang dewasa di luar lingkungan keluarga dan sekolah.

Perasaan ambivalensi ini bisa sangat membahayakan jika remaja terpengaruh pergaulan orang dewasa atau remaja yang dianggapnya lebih dewasa daripadanya yang mempunyai kecenderungan nakal. Maka dia bisa menggunakan kekuatan dan kekayaan orang tuanya untuk menopang keinginannya dalam menyesuaikan diri dan eksis dengan kelompoknya. Banyak orang tua yang tidak habis pikir tiba-tiba anaknya mempunyai keinginan dan kebutuhan yang melonjak besarnya atau keluar dari kebiasaan. Inilah posisi

\footnotetext{
${ }^{4}$ Nurihsan dan Agustin, Dinamika Perkembangan Anak ..., hlm. 68-69.

5 Nurihsan dan Agustin, Dinamika Perkembangan Anak ..., hlm.78, lihat juga http://hukum.unmuhjember.ac.id/in-dex.php/13-berita/11kenakalan-remaja, diakses tgl.17/10/2013.

${ }^{6}$ Zakiah Daradjat, Ilmu Jiwa Agama, (Jakarta: Penerbit Bulan Bintang, 1979), hlm. 108.
} 
puncak kelabilan remaja, kalau tidak diarahkan dan dibimbing dalam keadaan remaja seperti ini maka remaja akan terjerumus dalam kejahatan remaja (juvenile delinquency), namun sebaliknya jika mampu mendapatkan bimbingan dan diarahkan oleh orang yang tepat, maka akan bisa monorehkan prestasi puncaknya pada masa emas di remajanya (golden age adolescence).

\section{Ancaman Degradasi Moral Remaja Di Era Global}

Konsep dan standar baik buruk, patas dan tidak pantas telah berkembang sangat pesat sejajar dengan semakin majunya proses industrialisasi dan urbanisasi yang ditopang dengan cepatnya perkembangan teknologi informasi. Kesemuanya itu menjadi kesatuan yang tak terpisahkan dalam arus globalisasi. Globalisasi hanyalah ujung yang nampak, permukaan gunung es dalam samudera yang menyembul, namun di bawahnya terdapat sesuatu yang jauh lebih rumit dan besar, lebih berpengaruh dalam berbagai sisi kehidupan masyarakat, tergabung dalam arus besar industrialisasi dan kapitalisasi.

Semua masyarakat modern, terutama sekali di negara Barat, secara universal terkondisi menonjolkan Prestasi individual. Setiap orang didorong untuk mendapatkan sukses materiil. Akan tetapi masyarakat tidak selalu bisa menyediakan sarana dan fasilitas yang sama bagi setiap orang guna mencapai sukses materiil ini. Dalam mengejar kesuksesan ini menjadikan orang-orang bergerak di tengah struktur masyarakat yang terpecah-pecah, yang kemudian berubah menjadi kelompok atomistis (mikro) yang sangat mobil sifatnya. Dalam situasi demikian banyak orang yang mengalami depersonalisasi, di sisi lain kontrol sosial dan tradisi banyak kehilangan pengaruhnya. Sebaliknya, nafsu manusia modern untuk berkompetisi guna mencapai sukses materiil semakin menanjak, persaingan semakin sengit. Kondisi demikian jelas bisa memberikan tekanan batin pada setiap anggota masyarakat,banyak orang mengalami kekecewaan dan frustasi. ${ }^{7}$ termasuk di dalamnya para remaja.

1. Faktor-faktor Global Penyebab Degradasi Moral

Jika dipilah, maka ancaman globalisai terhadap degradasi moral remajaantara lain dalam keadaan:

\footnotetext{
${ }^{7}$ Kartono, Patologi Sosial ..., hlm. 85.
} 
a. Tersebar luasnya pandangan materialistis tanpa spiritualitas, ukuran kesuksesan lebih di ukur pada kesuksesan materiil dan mengenyampingkan moralitas.

b. Konsep moralitas kesopanan menjadi longgar karena terpengaruh budaya barat akibat dari mudahnya mencari informasi melalui ICT.

c. Budaya global menawarkan kenikmatan semu melalui $3 \mathrm{~F}$ : food, fashion dan fun.

d. Tingkat persaingan semakin tinggi, karena terbukanya sekat lokal dan kebanyakan bersifat online.

e. Masyarakat lebih bersifat individualistis dan kurang peduli dengan lingkungannya, sehingga kontrol moral terutama pada remaja menjadi rendah.

f. Keluarga kurang dapat memberi pengarahan, karena masing-masing orang tua sudah mempunyai kesibukannya sendiri atau bahkan broken home.

g. Sebagian besar sekolah tidak sepenuhnya dapat mengontrol perilaku siswa, karena keterbatasan waktu, sumber daya dan sumber dana ataupun kurang menekankan pentingnya moralitas.

Atau ringkasnya dalam bahasa Kartini Kartono pengaruh lingkungan yang buruk, ditambah dengan kontrol diri dan kontrol sosial yang semakin melemah dapat mempercepat munculnya kenakalan remaja ${ }^{8}$ ataupun degradasi moral remaja.

2. Bentuk-bentuk Penyelewengan Moral Remaja

Penyimpangan, degradasi, kenakalan atau bahkan kejahatan remaja selalu berlangsung dalam konteks antar personal dan sosio kultural. Kenakalan remaja dari sisi jenisnya setidaknya dapat dibagi menjadi empat macamyaitu:

a. Individual, kenakalan yang secara personal atau individualnya dengan ciri khas jahat (tidak normal) yang disebabkan oleh predisposisi dan kecenderungan penyimpangan prilaku yang diperkuat dengan stimuli sosial dan kondisi kultural

\footnotetext{
${ }^{8}$ Kartono, Patologi Sosial ..., hlm.78.
} 
b. Situasional, kenakalan yang dilakukan oleh anak normal, namun mereka banyak dipengaruhi oleh berbagai kekuatan situasional, stimuli sosial dan tekanan lingkungan yang 'menekan dan memaksa'.

c. Sistematis, kenakalan yang disistematisir dalam bentuk suatu organisasi struktural yaitu 'gang'. Kumpulan tingkah laku tersebut disertai pengaturan, status formal, peranan tertentu, nilai-nilai rite-rite, dan juga kebanggan, bahkan tidak jarang mereka menghasilkan bahasa-bahasa khas. ${ }^{9}$

d. Kumulatif, kenakalan yang terus menerus dilakukan sehingga bersifat kumulatif, ditiru diberbagai tempat dan menyebar luas di tengah masyarakat dan bisa mengakibatkan disintegrasi sosial. $^{10}$ Kumulatif bisa bersifat individu ataupun kelompok, pada tingkat akumulasi yang tinggi anak sudah sulit kembali pada prilaku yang sesuai dengan norma sosial yang ada. ${ }^{11}$

Adapun dari sisi bentuknya, setidaknya bisa dalam berbagai bentuk antara lain:

a. Kenakalan yang menimbulkan korban fisik pada orang lain: perkelahian, perkosaan, perampokan,pembunuhan, dan lain-lain.

b. Kenakalan yang menimbulkan korban materi: perusakan, pencurian, pencopetan, pemerasan, dan lain-lain.

c. Kenakalan sosial yang tidak menimbulkan korban di pihak orang lain: pelacuran, penyalahgunaan obat.

d. Kenakalan yang melawan status, misalnya mengingkari status anak sebagai pelajar dengan cara membolos, mengingkari status orang tua dengan cara minggat dari rumah atau membantah perintah mereka

e. Kenakalan remaja non-kriminal, yang mengalami masalah jenis ini cenderung tertarik pada kesenangan-kesenangan yang sifatnya menyendiri, apatis terhadap kegiatan

${ }^{9}$ Tentang korelasi komunitas, budaya dan kemunculan bahasa, lihat Heddy Shri Ahimsa-Putra, Strukturalisme Levi-Strauss, Mitos dan Karya Sastra, (Yogyakarta: Galang Press, 2001), hlm. 23-39.

${ }^{10}$ Kartono, Patologi Sosial ..., hlm.37 -46.

${ }^{11}$ Suyanto, dan Djihad Hisyam, Refleksi dan Reformasi Pendidikan di Indonesia Memasuki Milenium III, (Yogyakarta: Adicita Karya Nusa, 2000), hlm. 192. 
masyarakat atau sekolah. Remaja ini suka mengasingkan diri, menghindarkan diri dari kegiatan yang menumbuhkan kontak dengan orang lain. Perasaannya sangat peka dan mudah terluka, cepat tersinggung dan membesar-besarkan kekurangannya sendiri, dengan gejala umum sering menyendiri, melamun, apatis tidak bergairah, sangat mudah tersinggung, sangat mudah panik, sangat mudah bingung sehingga cenderung menjadi peminum, pemabuk, penghisap candu, narkotika, menjadi morfinis dan sebagainya, bahkan tega untuk bunuh diri. ${ }^{12}$

Karena pegaruh modernisasi dan globalisasi maka terjadi pergeseran batas kesopanan dan moralitas, dari yang dulunya tidak pantas menjadi biasa-biasa, dari yang dulunya sangat tidak mungkin dibayangkan menjadi kenyataan dan lain-lain. Khususnya dalam perilaku heteroseksual remaja, al-Migwar mencatat adanya berbagai perubahan di antaranya:

a. Perkembangan heteroseksual remaja kini cenderung lebih cepat daripada remaja tradisional. Berciuman saat berpacaran yang dianggap tabu pada remaja tradisional dianggap biasa saja pada remaja sekarang.

b. Waktu berkencan, cenderung lebih cepat dan berlanjut pada hubungan yang tetap, atau cepat berganti.

c. Pola pergaulan, remaja dulu bersifat lugu namun kini lebih mempunyai banyak alasan untuk mengikuti pola prilaku seksual yang baru karena meyakini bahwa itu merupakan keharusan atau orang lain juga melakukannya.

d. Remaja yang hamil di luar nikah dulu dianggap suatu aib yang besar dan dihukum orang tuanya dan diasingkan, kini seringkali diterima oleh orang tuanya, dinikahkan bahkan terkadang orang tua mereka ikut membesarkan dan menanggung biaya anak itu.

e. Hubungan seks, remaja dulu menganggap suatu yang tabu dan menimbulkan rasa bersalah, kini sebagian sudah menganggap biasa bahkan ada yang beranggapan bahwa orang yang saling mencintai sudah sewajarnya melakukan itu dengan didasari kasih sayang.

\footnotetext{
${ }^{12} \mathrm{http} / / /$ hukum.unmuhjember.ac.id/index.php/13-berita/11-kenakalanremaja, diakses tgl.17/10/2013.
} 
f. Keperawanan, asalnya dianggap suatu yang sangat sakral dan penting dalam perkawinan, kini sebagian menganggapnya kurang penting yang lebih penting adalah kesetiaan. ${ }^{13}$

Suatu pergeseran yang sangat mengerikan jika ditinjau dari sisi norma agama, namun dianggap biasa dari sisi norma sosial. Pergeseran norma sosial ini juga berlaku pada normanorma yang lain, seperti judi, minuman keras atau obat-obat terlarang, mencuri dan korupsi. Yang pantas dan yang tidak pantas menjadi sangat kabur tergantung pada masyarakat mana hal itu ditanyakan.Menjadi hal yang sangat penting diperhatikan adalah bagaimana kita mendidik generasi remaja bangsa ini dan dalam lingkungan yang bagaimana? Agar bisa tumbuh menjadi remaja yang brilian bukan delinkuen.

\section{Strategi Pendidikan Agama Islam Integral Progresif Fungsional}

Degradasi moral ataupun kadang disebut sebagai kenakalan remaja (juvenile delinquency), bukanlah murni kesalahan remaja secara sendiri. Mereka membangun dirinya dalam konteks lingkungan masing-masing yang bisa saja menstimuli menguatkan, bahkan mendorongnya dalam mencapai jati dirinya. Ada yang berhasil namun juga tidak jarang ada yang gagal.

Melihat sebab-sebab anak mengalami degradasi moral di era global sehingga cenderung jahat ternyata bermacam-macam, maka jika diatasi dari satu sisi saja akan menjadi kurang maksimal. Penanganan secara psikologis dengan pendekatan ilmu psikologi yang memang dibangun dari pengalaman dan analisa sosial, memang tidak salah, namun jika dijadikan sebagai satu-satunya, maka sangat besar kemungkinan tidak menyelesaikan masalah secara tuntas disebabkan karena perbedaan epistemologi ilmunya itu sendiri. ${ }^{14}$ Misalkan penanganan masalah remaja yang

${ }^{13}$ Al-Mighwar, Psikologi Remaja ..., hlm,144-145.

${ }^{14}$ Perbedaan epistemologi/ bangunan ilmu Islam dan 'barat' sudah bukan rahasia lagi bahkan keduanya secara ontologis terlibat dalam konflik yang berkepanjangan dari masalah politik, ekonomi, budaya yang berakakar dari peradaban Yudeo Kristiani Barat. Lihat Samuel P. Huntington, 2000, The Clash of Civilization and The Remaking of World Order, Terj. M.Sadat Ismail, Benturan Antar Peradaban dan Masa Depan Politik Dunia, (Yogyakarta: Penerbit Qalam, 1996), hlm. 390-415. 
beragama, namun didasarkan pada psikologi Sigmund Freud ataupun William James atau Anton P. Boisen yang jelas-jelas mereka menganggap negatif mengenai agama. James menganggap para nabi dan orang orang suci memiliki perasaan yang berlebihlebihan, melankolis, mengidap halusinasi dan delusi yang menyesatkan, mendengar atau melihat sesuatu yang khayali; Freud menganggap agama sebagai gejala neurosis obsesi yang universal; sedangkan Boisen menganggap bahwa agar orang bisa menghayati agama degan baik, dia harus menderita sakit jiwa terlebih Dahulu atau tahap Schizophrenia. ${ }^{15}$ Cara penanganan psikologis inilah yang kadang secara asumsi dasar berbeda dengan penanganan secara agama.

Pencegahan kenakalan remaja secara umum dapat dilakukan dengan berbagai cara baik moralitas maupun abolisionalistis. Cara moralitas menekankan pada upaya pembentukan dan pembinaan moral dan mental remaja, yang dapat dilakukan melalui penyuluhan kesadaran hukum bagi anak dan remaja, penanaman rasa tanggung jawab sosial, penanaman kesadaran beragama dan penyuluhan tentang sebab-musabab kenakalan remaja. Cara abolisionalitis dalam pencegahan kenakalan remaja dilakukan dengan mengurangi sebab-sebab yang mendorong anak remaja melakukan perbuatan delinkuen. Selain itu upaya pencegahan kenakalan remaja juga dapat dilakukan dengan cara berusaha mengerti pribadi anak dan minatnya serta memberikan cinta kasih yang simpatik.

Lebih dari itu sangat diperlukan untuk dapat mendekati persoalan degradasi moral remaja secara integral. Bahwa persoalan degradasi ini tidak lepas dari arus globalisasi, kapitalisasi dan pembentukan masyarakat industri dengan membawa dampak pada kehidupan sosial dan budaya masyarakat dunia, dan akar dari semua itu adalah paham materialisme. Semua keberhasilan, diukur dari kesanggupannya mengumpulkan materi dan bersenangsenang dengannya.

Berbeda dengan moralitas sosial yang mengalami pergeseran karena paham materialisme dan kapitalisme, aturan pokok moralitas pendidikan Islam tidak akan mengalami pergeseran walaupun zaman globalisasi teknologi terus berkembang. Aturan dan dalil-

\footnotetext{
${ }^{15}$ Kartini kartono dan Jenny Andari, Hygiene Mental dan Kesehatan Mental dalam Islam, (Bandung: Mandar Maju, 1989), hlm. 299.
} 
nya tetap, dengan prinsip bahwa Islam akan tegak dengan dibangunnya lima hal dalam rangka menghargai dan melindungi kehidupan manusia ${ }^{16}$ yaitu syahadat, salat, zakat, puasa bulan ramadan dan haji. Suatu yang haram juga tetap yaitu musyrik, zina, minum-minuman keras dengan segala bentuknya, mencuri, membunuh dan kafir/murtad dengan segala bentuknya. Suatu yang sudah tidak bisa ditawar lagi. Yang boleh berubah hanyalah metode menyampaikannya dengan menggunakan teknologi ataupun dengan pendekatan-pendekatan pembelajaran yang terbaru misalnya pembelajaran aktif ataupun kontekstual. Isi pesan Islam sebagai ruh spiritualitas tidak boleh redup apalagi berubah. Namun disini lebih tepat untuk mengemas pendidikan Islam dengan suatu strategi ${ }^{17}$ pembelajaran yang diajarkan pada remaja di era global ini dengan istiah integral progresif dan fungsional.

Integral, remaja perlu dikenalkan pemahaman pendidikan Islam secara menyeluruh/integral tentang hubungan dengan Allah swt., (tauhid), hubungan dengan sesama manusia yang meliputi kesalehan pribadi dan masyarakat secara adil serta hubungan manusia dengan alam semesta sebagai khalifatullah. Progresif, bersama Islam, remaja diajak untuk merasakan meraih kesuksesan, kemenangan, menyelesaikan masalah dan menemukan arti kehidupan. Remaja perlu dikenalkan progresifitas dan dinamisasi Islam yang pernah mampu mendorong dan memotifasi dan membentuk mental berbagai generasi dan merubah dirinya dari yang terjajah menjadi pribadi yang merdeka, dari lemah menjadi kuat, dari kebingungan menjadi menuju kepastian, dari inferior menjadi superior dan fungsional, remaja sangat membutuhkan pemahaman-pemahaman keagamaan yang mencerahkan dan mampu membimbingnya dalam menghadapi persoalan-persoalan yang dihadapi, memberi solusi dan mengarahkan pembentukan jati diri sebagai generasi yang tangguh dan percaya diri.

Pendidikan Islam Integral Progresif dan Fungsional dapat dikenalkan kepada para remaja dalam bentuk pembimbingan pro-

\footnotetext{
${ }^{16}$ Nurcholish Madjid, Islam Doktrin dan Peradaban, (Jakarta: Yayasan Wakaf Paramadina, 1992), hlm. 2.

${ }^{17}$ Kata strategi berasal dari bahasa Inggris 'strategy'atau bahasa Yunani 'Strategia' dari istilah militer yang keudian dipahami sebagai usaha untuk mendapatkan posisi yang menguntungkan dengan tujuan untuk mencapai kemenangan. Lihat: Djamaluddin Darwis, Dinamika Pendidikan Islam, Sejarah, Ragam dan Kelembagaan, (Semarang: RaSAIL, 2010), hlm. 87.
} 
blem solving dalam menghadapi persoalan diri dan masyarakatnya. Memberikan penyadaran siapa dirinya, siapa keluarganya, siapa temannya dan siapakah masyarakatnya dalam perspektif Islam yang progresif.

\section{Pendidikan Kepribadian}

Spiritualitas: mengajak untuk bersikap berserah diri (berIslam) kepada Allah swt., dengan segala konsekuensinya, menyadari dan bersikap bahwa Allah swt., sebagai sumber kehidupan dan kembalinya kehidupan, sumber kekuatan yang melindungi, sumber kejayaan yang sesungguhnya dalam bentuk mujahadah, ijtihad dan taqarrub. Hal ini akan dapat menghilangkan rasa takut dari ancaman siapa sajadan menghilangkan keraguan yang biasa muncul pada masa remaja.

a. Fisik: membentuk kesadaran remaja dan perilaku dalam solusi praktis untuk menyelesaikan persoalannya bahwa orientasi perbuatan yang membanggakan bukan padarupa dan fisik materiil tetapi lebih berorientasi pada hati dan perbuatanmu. Memberi kesadaran solusi menahan gejolak remaja dengan berpuasa.

b. Psikis: memberi kesadaran mengendalikan diri sebagai kekuatan dan kunci sukses remaja.

2. Pendidikan keluarga, remaja sangat membutuhkan untuk dikenalkan dengan kondisi keluarga yang menjaga diri dari api neraka, ataupun merasakan kenyamananya, kebahagiaanya dan ketenteramannya.

3. Pendidikan dalam lingkungan sekolah. Remaja sangat membutuhkan sekolah yang menjunjung tinggi keunggulan budi pekerti dalam praktik keseharian, akhlakul karimah yang tidak hanya berkompetisi dalam hal materiil namun menghargai kepribadian yang luhur.

4. Pendidikan dalam sosial masyarakat. Remaja perlu selalu dibimbing untuk mampu merasakan bedanya masyarakat yang baik yang diridhai oleh Allah dengan pola masyarakat yang jauh dari nilai-nilai kebaikan. Sehingga remaja akan dapat memilih dan merasa nyaman hidup dengan masyarakat yang secara moralitas baik dan akan merasa tidak nyaman hidup di tengah masyarakat yang moralitasnya rusak. 


\section{E. Penutup}

Dengan menyadari peran dan posisinya masing-masing dalam kehidupan ini, sangat bisa menjadikan remaja untuk menyeleksi mana yang baik dan mana yang buruk dari norma-norma globalisasi dan dapat membentengi diri dari norma negatif globalisasi yang cenderung menghancurkan kemanusiaan, serta dengan mengenalkan Islam yang integral, progresif dan fungsional kepada para remaja diharapkan mereka akan dapat melalui masa remajanya dengan penuh Prestasi dan keluhuran budi berdasar akhlakul karimah dan jauh dari dekadensi moral.

\section{Kepustakaan}

Ahimsa-Putra, Shri, Strukturalisme Levi-Strauss, Mitos dan Karya Sastra, Yogyakarta: Galang Press, 2001.

Al-Mighwar, Muhammad, Psikologi Remaja, Petunjuk Bagi Guru dan Orang Tua, Bandung: Pustaka Sia, 2011.

Arief, Armai, Tantangan Pendidikan di Era Global, Artikel, Jakarta: FAI-UMJ, 2010.

Aziz, Abdul, Esai-Esai Sosiologi Agama, Jakarta: Diva Pustaka, 2006.

Darwis, Djamaluddin, Dinamika Pendidikan Islam, Sejarah, Ragam dan Kelembagaan, Semarang: RaSAIL (Ranah IlmuIlmu Sosial Keagamaan dan Interdisiplier, 2010.

Daradjat, Zakiah, Ilmu Jiwa Agama, Jakarta: Bulan Bintag, 1979.

Jenggis P, Akhmad, 10 Isu Global di Dunia Islam, NFP Yogyakarta: Publishing, 2012.

Kartono, Kartini dan Jenny Andari, Hygiene Mental dan Kesehatan Mental dalam Islam, Bandung: Mandar Maju, 1989.

Kartini Kartono, Patologi Sosial 2, Kenakalan Remaja, Jakarta: Raja Grafindo Persada, 2013.

Madjid, Nurcholish, Islam Doktrin dan Peradaban, Jakarta: Yayasan Wakaf Paramadina, 1992.

Nurihsan, Achmad Juntika dan H. Mubiar Agustin, Dinamika Perkembangan Anak \& Remaja, Tinjauan Psikologi, Pendidikan, dan Bimbingan, Bandung: Refika Aditama, 2013. 
Huntington, Samuel P., The Clash of Civilization and TheRemaking of World Order,1996. Terj. M.Sadat Ismail, Benturan Antar Peradaban dan Masa Depan Politik Dunia, Yogyakarta: Qalam, 2000.

Suyanto, dan Djihad Hisyam, Refleksi dan Reformasi Pendidikan di Indonesia Memasuki Milenium III, Yogyakarta: Adicita Karya Nusa, 2000.

Yin-wah Chu: Sociology, Global Culture: hegemony or plurality?,www.edb.gov.hk/FileManager/TC/Content_5205/chuyw_ global_culture_text.ppt

http://aurabianglala.blogspot.com/2012/12/periode-emas-dan-kritis-pada-anak.html

http://hukum.unmuhjember.ac.id/index.php/13-berita/11-kenakalan-remaja.

http://hukum.unmuhjember.ac.id/index.php/13-berita/11-kenakalan-remaja.

http://www.m-edukasi.web.id/2013/08/budaya-dan-Karakterwajah-kurikulum-baru.html, Yanuri Natalia Sunata Copyright www.m-edukasi.web.id Media Pendidikan Indonesia. 
Vol. 7, Nomor 2, Oktober 2013

\title{
Madrasah dan Ujian Nasional
}

\author{
Supa'at \\ Sekolah Tinggi Agama Islam Negeri Kudus \\ Email: supa'at@gmail.com
}

\begin{abstract}
This research analysis the implication of the policy of the national final exams (Ujian Nasional-UN) in basic to high school that conducts every year by the government, the ministry of education and culture. This researchnot discussabout the validity of UN as government policy, butthe main focus of this research is the implication of UN to madrasah as Islamic education institution that has unique and different character from general school. AsIslamic education,curriculum of madrasah based on the Islamic teachings which the sublime behavior as the final objective of Islamic education. In reality, the policy of UN has caused madrasah to become trapped in practical efforts to help student pass by focusing on repetitive practice of test in examination subject.The defication of test scores and the application of the policy standardization have result in the process education causing fear in students, teachers, and madrasah management. Finaly, students experient stress and depressiondue to fear of failing the UN.
\end{abstract}

Keywords: final exams (UN), UN policy implications, Islamic education, madrasah.

\begin{abstract}
Abstrak
Penelitian ini mengkaji implikasi dari kebijakan Ujian Nasional (UN) mulai dari Sekolah Dasar sampai Sekolah Menengah Atas yang dilakukan setiap tahun oleh Pemerintah, Kementrian Pendidikan dan Kebudayaan. Penelitian ini tidak membahas tentang keabsahan UN sebagai kebijakan pemerintah, tetapi fokus utama dari penelitian ini adalah implikasi dari UN untuk madrasah sebagai institusi pendidikan Islam yang memiliki Karakter yang unik dan berbeda dari sekolah umum. Sebagai pendidikan Islam, kurikulum madrasah didasarkan ajaran Islam yang luhur perilaku sebagai tujuan akhir pendidikan Islam. Pada kenyataannya, kebijakan UN telah menyebabkan madrasah menjadi terjebak dalam upaya praktis untuk membantu siswa lulus dengan berfokus pada praktek berulang tes dalam subjek pemeriksaan. Perolehan nilai ujian dan penerapan standarisasi kebijakan mengakibatkan rasa takut pada siswa, guru, dan manajemen madrasah. Akhirnya, siswa mendapati stres dan depresi karena takut gagal dalam UN.
\end{abstract}

Kata kunci: Ujian Nasional (UN), Implikasi Kebijakan Ujian Nasional, Pendidikan Islam, Madrasah.

ISSN 1979-1739

(C) 2013 Nadwa | IAIN Walisongo

http://journal.walisongo.ac.id/index.php/nadwa 


\section{A. Pendahuluan}

Secara kelembagaan, eksistensi madrasah sebagai lembaga pendidikan dalam konteks sistem pendidikan nasional telah mendapat status seperti yang diperjuangkan selama ini, yaitu sama dengan sekolah. Secara yuridis pengakuan tersebut tertuang dalam Undang-Undang Nomor 2 Tahun 1989danUndang-Undang Nomor 2 Tahun 1989 tentang Sistem Pendidikan Nasional. Pengakuan ini menjadi penting bagi madrasah, karena selama ini madrasah kurang mendapatkan perhatian yang sewajarnya dari pemerintah, bahkan pada dataran tertentu dipandang dengan sebelah mata dan diperlakukan secara diskriminatif. Hal ini terjadi karena madrasah lebih dipandang sebagai lembaga keagamaan (lembaga dakwah) ketimbang sebagai lembaga pendidikan. Sudut pandang ini juga dapat dimengerti dan dipahami karena madrasah selama ini menjadikan ilmu-ilmu agama (ulümuddin) sebagai tema sentral pembelajarannya, mata pelajaran umum hanya sebagai tambahan.

Konsekuensi dari pengakuan sama tersebut, kurikulum madrasah diperbaharui dengan kurikulum 1994 dengan perbandingan alokasi waktu antara 16-18\% untuk pelajaran agama dan antara $82-86 \%$ mata pelajaran umum, dengan catatan bahwa alokasi waktu mata pelajaran umum muatan nasional diberlakukan $100 \%$ sama dengan sekolah umum setingkat. ${ }^{1}$ Dengan kata lain, pengakuan dan status sama dengan sekolah umum ini madrasah harus tunduk dan mengikuti semua regulasi dan kebijakan yang diambil oleh Kementerian Pendidikan dan Kebudayaan. UN adalah salah satu contoh kebijakan pendidikan tersebut.

Meskipun kebijakan ini oleh sementara kalangan dipandang sebagai langkah maju, namun tidak semua kalangan menerima sepenuhnya, faktanya tidak semua madrasah pada saat itu patuh terhadap keputusan ini. Ketidakpatuhan sebagian madrasah ini lebih didasarkan atas kekhawatiran madrasah akan kehilangan jati dirinya sebagai lembaga pendidikan Islam, yaitu sebagai agen pencetak kader ulama. ${ }^{2}$ Dalam istilah Azyumardi Azra, madrasah dan pesantren akan menghadapi "krisis identitas", karena muatan

${ }^{1}$ Departemen Agama RI, Sejarah Madrasah, (Jakarta: Direktorat Jenderal Pendidikan Islam, 2004), hlm. 34.

${ }^{2}$ Suwito \& Fauzan, (Ed.), Perkembangan Pendidikan Islam di Nusantara: Studi Perkembangan Sejarah dari Abad 20 M. (Bandung, Angkasa, 2004), hlm.203. 
pelajaran umum yang begitu besar pada gilirannya dapat menghilangkan misi, substansi, dan Karakternya sebagai lembaga pendidikan Islam. ${ }^{3}$ Sementara bagi yang menerima berargumen bahwa kebijakan ini merupakan pengakuan yang lebih nyata terhadap eksistensi madrasah sekaligus langkah awal yang positif bagi proses pengintegrasian madrasah dalam sistem pendidikan nasional. Wacana "integrasi" tersebut muncul sebagai respons atas realitas dualisme pengelolaan pendidikan, yaitu antara Kementerian Pendidikan dan Kebudayaan dan Kementerian Agama. ${ }^{4}$

Kekhawatiran lain yang muncul terkait dengan status dan format kurikulum barunya ini adalah alumni madrasah tidak memperoleh keduanya baik pengetahuan umum maupun pengetahuan agama. Hal ini terjadi lebih disebabkan karena pengakuan legal formal tersebut tidak berbanding lurus dengan realitas obyektif di lapangan di mana madrasah menghadapi berbagai problem dan keterbatasan, baik infrastruktur pembelajaran maupun sumberdaya manusia. Menurunnya kualitas capaian/penguasaan ilmu-ilmu agama siswa madrasah lebih disebabkan karena keterbatasan alokasi waktu untuk pembelajaran sehingga sulit untuk mencapai kompetensi atau standar sebagaimana diharapkan.

UN sebagai sebuah kebijakan merupakan aplikasi dari UU No: 20 tahun 2003 tentang Sistem Pendidikan Nasional, khususnya pasal 57 ayat (1): Evaluasi dilakukan dalam rangka pengendalian mutu pendidikan secara nasional ...".Selanjutnya pada ayat (2) disebutkan: "Evaluasi dilakukan terhadap peserta didik, lembaga, dan program pendidikan pada jalur formal...". Kemudian, pasal 58 ayat (1) disebutkan: "Evaluasi hasil belajar peserta didik dilakukan oleh pendidik untuk...”. Secara teoritik UN merupakan kegiatan pengukuran dan penilaian kompetensi peserta didik secara nasional pada jenjang pendidikan dasar dan menengah. Dari sudut kebijakan, tujuan diselenggarakan UN antara lain yaitu untuk mengukur pencapaian kompetensi lulusan peserta didik (siswa) secara nasional pada mata pelajaran tertentu dalam kelompok mata pelajaran ilmu pengetahuan dan teknologi serta untuk mempetakan tingkat pencapaian hasil belajar siswa pada tingkat sekolah dan daerah.

\footnotetext{
${ }^{3}$ Jajat Burhanudin \& Dina A., Eds.,Mencetak Muslim Modern: Peta
} Pendidikan Islam Indonesia, (Jakarta: Raja Grafindo Persada, 2006), hlm. 4.

${ }^{4}$ Departemen Agama RI, Sejarah Madrasah, 2004, hlm.145. 
UN yang pada awalnya merupakan satu-satunya alat yang digunakan untuk mengukur keberhasilan siswa dalam belajar di sekolah, karena berbagai kritik dan saran telah terjadi perubahan signifikan. Contoh, formula baru kelulusan siswa mulai tahun 2010 adalah menggabungkan nilai UN dengan nilai sekolah. Rumus yang ditawarkan pemerintah untuk nilai gabungan $=(0,6 \mathrm{x}$ nilai $\mathrm{UN})+(0,4 \mathrm{x}$ nilai sekolah). Nilai sekolah dihitung dari nilai rata-rata ujian sekolah dan nilai rapor semester 3-5 untuk tiap mata pelajaran UN. Adapun kriteria kelulusan ujian sekolah diserahkan kepada sekolah. Dengan perubahan ini seharusnya UN tidak lagi menghantui siswa/pihak terkait. Namun faktanya, ketegangan tetap mewarnai pada saat-saat menjelang pelaksanaan dan pengumuman hasil kelulusan. Hal ini karena masih dominannya hasil UN sebagai penentu kelulusan siswa.

Kebijakan baru yang memasukkan nilai sekolah menjadi bagian dari penentuan kelulusan bukan tanpa celah untuk disiasati oleh pihak yang hanya semata-mata mengejar Prestasi dalam meluluskan siswa sekolah. Pengkatrolan nilai sekolah untuk siswa mungkin saja dilakukan pihak sekolah yang menginginkan para siswa lulus sebanyak-banyaknya agar dianggap sebagai satu Prestasi sekolah. Nilai yang dikatrol bisa jadi berbeda dengan nilai hasil UN. Jika ini terjadi maka sangat mungkin akan tampak ketimpangan antara hasil sekolah dengan hasil UN yang seharusnya tidak boleh terjadi. Hal ini terjadi karena setiap materi tes yang baik dan teruji seharusnya akan menghasilkan nilai yang sama atau tidak jauh berbeda antara nilai sekolah dan nilai UN.

Dari sisi konsep dan teori pembelajaran, ujian yang berbentuk "paper and pencil test" (seperti UN) bukanlah segala-galanya, dalam arti bahwa ia tidak dapat mengukur semua aspek perolehan belajar para siswa. Tes tertulis hanya dapat mengukur aspek-aspek tertentu saja khususnya pada ranah kognitif. ${ }^{5}$ Oleh karenanya, secara akademik hasil UN seharusnya tidak boleh dijadikan penentu untuk kelulusan. Karena UN bukan suatu tes multifungsi yang cocok untuk semua (a test fits for all). Di samping fakta non kependidikan lainnya yang terjadi di lapangan, yaitu kecemasan yang melanda banyak pihak tidak hanya siswa, orang tua, guru dan kepala sekolah tetapi juga pimpinan daerah. Fakta lain yang tidak kalah pentingnya adalah, hasil UN tidak jarang dijadikan sebagai

${ }^{5}$ Nana Sudjana, Penilaian Hasil Proses Belajar Mengajar, (Bandung: Remaja Rosdakarya, 1995), hlm. 15. 
prestise/gengsi sekolah dan martabat daerah. Tidak hanya guru dan Kepala Sekolah tapi pimpinan/birokrat daerah pun ikut "mengatur cara" agar sekolah-sekolah di wilayahnya sukses dalam meluluskan siswa dengan hasil yang maksimal.

Kebijakan dalam pendidikan, dalam istilah House dan Mathison disebut dengan social intervention in education, tujuannya adalah untuk perubahan dan perbaikan. ${ }^{6}$ Harrington menyebutnya dengan istilah improvement process. ${ }^{7}$ Meskipun improvement itu akan mengakibatkan perubahan, namun "perubahan" tidak harus diasumsikan akan membawa perbaikan. Tidak jarang suatu perubahan sebagai"hasil"kebijakan tidak mampu menyentuh aspek substantifdari objek kebijakan tapi hanya menyentuh permukaan atau sekadar formalitas. Oleh karenanya, menurut Hopkins, dalam konteks pendidikan improvement diartikan sebagai " $a$ distinct approach to educational change that enhances student outcomes as well as strengthening the school's capacity for managing chan$g e^{\prime \prime}$.

Di samping memiliki Karakteristik khusus, keberhasilan suatu kebijakan dalam pendidikan tidaklah berdiri sendiri tetapi banyak faktor yang terlibat, mempengaruhi dan bahkan menentukan. Tidak hanya faktor internal tetapi juga berbagai faktor eksternal pendidikan. Oleh karenanya tidak jarang suatu kebijakan yang didesain untuk menghasilkan perubahan, hanya berhenti sebatas kebijakan itu sendiri tanpa mampu menghasilkan perubahan sebagaimana diinginkan. Seperti dikatakan oleh Fullan, "the purpose of educational change presumably is to help school accomplish their goals more effectively by replacing some structures, program and/or practice with the better ones".

Terimplementasi atau tidaknya suatu kebijaksanaan, berhasil tidaknya implementasi kebijaksanaan, ditentukan oleh banyak faktor. Menurut Ali Imron, ada enam faktor yang mempengaruhi im-

${ }^{6}$ Seidman, E., Handbook of social intervention. (Beverly Hill/London/ New Delhi: Sage Publication, 1983), hlm.323.

${ }^{7}$ Harrington, H. J, The improvement process: How America's Leading Company Improve Quality, (New York: Mc Graw Hill Book Company, 1987), hlm. xiii.

${ }^{8}$ Hopkins, D., Every School a Great School: Realizing the Potential of System Leadership, (New York: Mc Graw Hill-Open University Press, 2006), hlm.ix.

${ }^{9}$ Fullan, M. G. The New Meaning of Educational Change, (England: Cassell Educational Limited, 1991), hlm.15. 
plementasi suatu kebijakan: (1)Kompleksitas berbagai kebijakan yang telah dibuat; 2) Ketidakjelasan rumusan masalah kebijakan dan alternatif pemecahan masalah kebijakan; 3) Ketersediaan sumber-sumber potensial yang dapat mendukung pelaksanaan kebijakan; 4) Kemampuan dan keahlian pelaksana kebijakan; 5) Dukungan dari khalayak sasaran kebijakan; 6) Efektivitas dan efisiensi birokrasi. ${ }^{10}$

Penelitian ini tidak membahas validitas UN sebagai sebuah kebijakan, namun lebih difokuskan pada realitas pelaksanaan UN terutama pada lembaga pendidikan madrasah. Secara spesifik penelitian ini akan membahas pengaruh $\mathrm{UN}$ pada madrasah di $\mathrm{Ku}-$ dus, khususnya Madrasah Aliyah. Secara metodologis penelitian ini menggunakan pendekatan kualitatif-fenomenologis dengan teknik pengumpulan data: observasi partisipatori, indepth interview, kajian dokumen.

\section{B. Ujian Nasional}

Seperti telah disinggung di atas Ujian Nasional (UN) adalah kebijaan kependidikan yang diambil oleh pemerintah, secara umum tujuannya adalah untuk mengevaluasi kinerja pendidikan (dasar dan menengah) secara nasional. Dengan evaluasi sebuah kegiatan akan diketahui keberhasilan atau bahkan kegagalanya. Secara teoritik, evaluasi adalah sebuah aktivitas mengumpulkan informasi dan membandingkan antara tujuan yang telah ditetapkan dengan hasil yang telah dicapai. Untuk memberi gambaran lebih luas tentang evaluasi,berikut dipaparkan beberapa definisi evaluasi yang dirumuskan oleh para ahli, antara lain: (1) One prominent, long-standing definition states that evaluation involves comparing objectives and outcomes... ${ }^{11}(2)$ Evaluation is the systematic assessment/investigationof the worth or merit of same object. ${ }^{12}(3)$ Evaluation is the process of determinis to what extened the Educational objectives are actually being realized. ${ }^{13}(4)$ Evaluation

${ }^{10}$ Ali Imron, Kebijakan Pendidikan di Indonesia: Proses Produk dan Masa Depannya. (Jakarta: Bumi Aksara, 1996). hlm.76-77.

${ }^{11}$ Stuflebeam D.L. et al., Educational Evaluation and Decesion Making. (Itasca, IL: Peacock, 1971, hlm.3.

${ }^{12}$ Stuflebeam, Educational Evaluation ..., hlm. 3.

13 Tyler, R.W., Basic Principle of Curriculum and Instruction. (IL. University of Chicago Press, 1950), hlm. 69. 
is providinginformation for decision making. ${ }^{14}(5)$ Evaluation is the comparison of performance to same standards to determine whether discrepancies existed. ${ }^{15}$

Menurut Anas Sudjiono, ruang lingkup evaluasi meliputi tiga aspek, yaitu: 1) evaluasi mengenai program pengajaran; 2) evaluasi mengenai proses pengajaran; 3) evaluasi mengenai hasil belajar (hasil pengajaran). ${ }^{16}$ Dengan demikian, secara umum evaluasi pembelajaran bertujuan untuk mengumpulkan informasi terkait dengan proses pembelajaran yang telah dilakukan untuk menentukan tingkat capaian/hasil pembelajaran yang telah dilakukan. Karena tidak mungkin bisa diketahui Prestasi belajar siswa jika di akhir program belajar tidak dilakukan evaluasi dengan mengukur (pengukuran) dan menilai (penilaian). Pengukuran pada dasarnya adalah kegiatan penentuan angka untuk menggambarkan Karakteristik suatu obyek. Dalam konteks UN, akan menghasilkan angka (nilai) yang bermanfaat untuk memperoleh, menganalisis, dan menafsirkan data tentang proses dan hasil belajar siswa. Data tersebut dapat menjadi informasi yang bermakna dalam pengambilan keputusan untuk program pendidikan selanjutnya.

Penilaian dalam dunia pendidikan tujuan dasarnya, antara lain: 1) menentukan tingkat ketercapaian kemampuan dasar; 2) mengetahui pertumbuhan dan perkembangan kemampuan siswa; 3) mendiagnosis kesulitan belajar siswa; 4) meningkatkan motivasi belajar; 5) mendorong guru untuk mengajar lebih baik; 6) memberikan informasi kepada orang tua dan masyarakat sebagai bentuk akuntabilitas lembaga pendidikan. ${ }^{17}$

Sebagaimana dijelaskan dalam Keputusan Menteri PendidikanNasional Nomor 153/2003; tujuan penyelenggaraan UAN (UN) adalah untuk; 1) mengukur pencapaian hasil peserta didik; 2) mengukur mutu pendidikan di tingkat nasional, provinsi, kabupaten/kota, dan sekolah/madrasah; 3) pertanggungjawaban penyelenggaraan pendidikan secara nasional, provinsi,

${ }^{14}$ Cronbach, L.J., Course Improvement Trough Evaluation. (Teacher College Record, 1963), hlm.64.

${ }^{15}$ Stuflebeam, Educational Evaluation ...,hlm.7.

${ }^{16}$ Anas Sudjiono, Pengantar Evaluasi Pendidikan. (Jakarta: Rajawali Pers, 2001), hlm. 29.

${ }^{17}$ Djemari Mardapi, Penyusunan Tes Hasil Belajar, (Yogyakarta: Program Pasca Sarjana Universitas Negeri Yogyakarta, 2004), hlm.13-19. 
kabupaten/kota, sekolah/madrasah, kepada masyarakat. Sedangkan fungsi UN adalah: 1) alat pengendali mutu pendidikan secara nasional; 2) pendorong peningkatan mutu pendidikan; 3) bahan dalam menentukan kelulusan peserta didik; 4) bahan pertimbangan dalam seleksi penerimaan peserta didik pada jenjang yang lebih tinggi.

UN yang dilaksanakan saat ini sesungguhnya merupakan modifikasi atau penyempurnaan model yang selama ini sudah ada,meskipun nama dan sistemnya berbeda atau berubah. Satu hal yang sama adalah sistem ini bertujuan untuk mengetahui hasil belajar dan pembelajaran yang telah dilakukan. Untuk mengetahui perkembangan UN di Indonesia, berikut dijelaskan sekilas tentang perkembangan UN:

1. Tahun 1965-1971, sistemnya bernama Ujian Negara. Berlaku hampir di semua mata pelajaran, semua jenjang pendidikan yang ada di Indonesia, satu komando dan satu kebijakan pemerintah pusat.

2. Tahun 1972-1979, sistemnya bernama Ujian Sekolah. Jadi sekolah yang menyelenggarakan ujian sendiri-sendiri. Semuanya diserahkan kepada sekolah, pemerintah pusat hanya membuat kebijakan-kebijakan umum terkait dengan ujian yang dilaksanakan.

3. Tahun 1980-2000, sistemnya bernama Evaluasi Belajar Tahap Akhir Nasional (EBTANAS). Dalam ujian ini, dikembangkan perangkat ujian paralel untuk setiap mata pelajaran yang diujikan. Sedangkan terkait dengan penggandaan dan monitoring soal dilaksanakan oleh daerah masing-masing.

4. Tahun 2001-2004, Sistemnya bernama Ujian Akhir Nasional (UNAS). Hal yang berbeda dari UNAS adalah penentuan kelulusan siswa. Dalam EBTANAS kelulusannya berdasarkan nilai dua (2) semester rapor terakhir dan nilai EBTANAS murni, sedangkan UNAS ditentukan pada mata pelajaran secara individual.

5. Tahun 2005-2009, sistemnya tetap bernama UNAS dengan perubanan sistem yaitu pada target wajib belajar pendidikan (SD/MI/SD-LB/MTs/SMP/SMP-LB/SMA/MA/SMK/SMA-

LB) sehingga nilai kelulusan ada target minimal.

6. Tahun 2010-Sekarang, sistemnya bernama Ujian Nasional (UN). Untuk UN tahun 2012, ada ujian susulan bagi siswa 
yang tidak lulus UN. Dengan target, para siswa yang ujian dapat mencapai nilai standar minimal UN sehingga dapat lulus UN dengan baik.

Sampai tahun 1990, UN/EBTANAS hanya diikuti oleh lembaga pendidikan (sekolah) di bawah naungan Kementerian Pendidikan dan Kebudayaan, dengan demikian madrasah tidak mengikuti program tersebut. Baru pada tahun 1990-an, madrasah mulai mengikuti program EBTANAS. Meskipun demikian, baik di sekolah umum ataupun madrasah tidak mengikutkan bidang studi agama (PAI) sebagai mata pelajaran yang dievaluasi/diujikan tersebut. Selain mengikuti ujian nasional, dengan jumlah mata pelajaran yang sama seperti yang diujikan kepada siswa SMA, untuk siswa MA harus mengikuti Ujian Akhir Madrasah Berstandar Nasional (UAMBN), yakni berupa mata pelajaran yang tergabung dalam rumpun PAI yang meliputi mata pelajaran: Quran-Hadis, Aqidah Akhlak, Fiqh, Sejarah Kebudayaan Islam, Bahasa Arab. Ujian ini biasanya dilaksanakan selama tiga hari. Di samping UN dan UAMBN masih ada lagi jenis ujian akhir,yaitu Ujian Madrasah. Mata pelajaran yang diujikan adalahmata pelajaran agama Islam yang terangkum dalam Kurikulum Lokal sesuai visi-misi masing-masing madrasah, khususnya madrasah swasta.

Secara spesifik tujuan UAMBN adalah untuk mengukur capaian hasil belajar peserta didik di akhir jenjang pada satuan pendidikan sesuai dengan standard kompetensi lulusan yang ditetapkan secara nasional. Hasil UAMBN juga sebagai bahan dalam pemetaan dan umpan balik untuk perbaikan program pembelajaran PAI dan bahasa Arab pada madrasah. Secara teknis pelaksanaan ujian ini mengadopsi sistem yang ada pada UN, dan soal ujiannya juga ditetapkan oleh pemerintah pusat.

Tidak diujikannya bidang studi agama (PAI) dalam UN tetap menjadi pertanyaan besar hingga kini. Bangsa Indonesia yang dikenal dengan bangsa yang agamis ini pada kenyataannya dalam sistem pendidikannya, pendidikan agama tidak termasuk bidang studi yang diujikan dalam sistem evaluasi akhirnya. Meskipun mata pelajaran agama, sesuai UU No: 2 tahun 1989 maupun UU No: 20 Tahun 2003, wajib diberikan pada semua jenjang pendidikan mulai sekolah dasar sampai perguruan tinggi. Bagaimana nanti, jika standar kelulusan sekolah tak sedikitpun mencerminkan 
Pendidikan Agama bagi bangsa. Lalu, nilai dan norma dasar apa yang dipakai untuk membangun bangsa ini kalau tak ada dasardasar agama tersebut.

Dengan tidak mengikutkan bidang studi agama dalam UN, secara tidak langsung standar kelulusan tak ada nilai moral/akhlaknya. Hal ini sangat bertentangan dengan tujuan pendidikan yang ingin dicapai, sebagaimana dirumuskan dalam tujuan pendidikan nasional, antara lain adalah berimanan dan bertaqwa. Dengan begini kemampuan manusia hanya diukur dengan deret angka, jauh dari realitas atau bahkan tak mewakili sama sekali. Langsung atau tidak pendidikan telah tidak mampu mencerdaskan lagi secara spiritual. Bahkan menjadikan peserta didik menjadi menjadi robot, karena mengukur kemampuan manusia hanya sebatas dengan ukuran nominal. Semua itu telah membuat degradasi nilai-nilai pendidikan dan sangat bertentangan dengan konstitusi negara.

Dengan tidak mengikutkan pendidikan agama sebagai mata pelajaran yang di-UN-kan, berdampak pada perlakuan anak didik terhadap mata pelajaran agama menjadi berbeda. Mereka menganggap sepele terhadap mata pelajaran agama dan cenderung apatis dengan kegiatan-kegiatan simbol-simbol yang berbau agama. Padahal dalam kehidupan sehari-hari mereka pasti bersinggungan dengan nilai-nilai tersebut. Hasilnya pendidikan tak lagi membangun manusia secara utuh. Namun, hanya mengoptimalkan intelegensi yang diharapakan oleh pasar tanpa punya rasa kemanusiaan. Fenomena tawuran dan prilaku dekadensi lainya menjadi bukti akan keringnya manusia Indonesia dari norma dan nilai agama.

\section{Ujian Nasional untuk Madrasah}

Secara umum, tidak terkecuali madrasah, pelaksanaan UN telah membuat lembaga pendidikan kita kalang kabut dan terperosok dalam lubang hitam disorientasi pendidikan. Madrasah sebagai lembaga pendidikan yang mengemban dua misi sekaligustransformasi pengetahuan umum dan pengetahuan agama Islamjuga mengalami hal yang sama. Keadaan ini menjadi semakin berat karena madrasah memikul beban tambahan yaitu membentuk pribadi-pribadi yang berwawasan luas dan berakhlakul karimah.

Data dan pembahasan tentang UN dalam tulisan ini tidak dalam konteks membahas setuju atau tidak setuju berbagai hal yang terkait dengan pelaksanaan UN untuk MA, tetapi lebih 
difokuskan pada pengaruh implementasi kebijakan UN tersebut terhadap eksistensi dan jati diri MA sebagai Sekolah Menengah Umum berciri khas agama Islam. Dalam pandangan penulis kebijakan UN yang juga diberlakukan untuk MA adalah kebijakan wajib yang tidak bisa ditolak sebagai konsekuensi menyatunya sistem pendidikan madrasah dalam sistem pendidikan nasional, apapun yang terjadi dan apapun hasilnya semua MA harus tunduk dan mengikuti kebijakan tersebut.

Seperti diketahui perdebatan tentang UN sudah terjadi sejak digulirkannya kebijakan tersebut pada tahun ajaran 2002/2003 yang pada awalnya bernama EBTANAS dan UAN. Oleh karenanya membahas setuju atau tidak setuju pelaksanaan UN untuk MA dalam tulisan ini tidak memiliki signifikansi dengan tema penelitian ini. Data yang dikumpulkan terkait pelaksanaan UN untuk MA di sini difokuskan pada bagaimana pengaruh kebijakan tersebut pada implementasi MA sebagai sekolah menengah umum berciri khas Islam.

Kebijakan UN sebagai salah satu upaya untuk menjamin kualitas proses dan hasil pendidikan semua pihak di MA sepakat, karena tidak mungkin kualitas pendidikan akan tercapai manakala tidak ada standar yang jelas sebagaitolok ukur norma dan acuan. Namun persoalannya adalah standar yang ditetapkan saat ini lebih pada hasil bukan proses, sehingga yang terjadi standar yang ditetapkan berubah menjadi penyeragaman realitas yang sebenarnya beragam baik input maupun prosesnya. Ketika UN yang berorientasi pada hasil tersebut diterapkan pada seluruh lembaga pendidikan sesuai tingkatannya tanpa mempertimbangkan realitas obyektif pada skala mikro sekolah/madrasah, di situlah kemudian berbagai persoalan muncul. Mana mungkin akan diperoleh hasil yang obyektif manakala standar dan alat ukur yang digunakan sama untuk mengukur obyek yang berbeda. Mulai dari perbedaan negeri-swasta, sekolah-madrasah, wilayah pedesaan-perkotaan, sekolah madrasah maju-sedang-tidak maju (dengan indikator skor akreditasi A, B, C/izin operasional), dan lain-lain. Hal-hal inilah yang kemudian memicu munculnya penolakan terhadap pelaksanaan UN.

Bila ditelusuri lebih mendalam akar masalahnya adalah ketidaksiapan sekolah/madrasah untuk melaksanakan UN tersebut. Banyak hal yang melatarbelakangi ketidaksiapan tersebut, mulai dari kemampuan siswa, kompetensi guru, sarana/fasilitas/pembia- 
yaan pendidikan, dan lain-lain. Maka tidaklah mengherankan kalau UN ini telah berpengaruh (effect) dan berdampak (impact) besar tidak hanya pada praktik pendidikan tapi juga pada kehidupan sosial.

Dalam konteks sistem pendidikan madrasah, pada satu sisi kebijakan ini telah berhasil merubah pandangan masyarakat menjadi semakin positif terhadap madrasah, tetapi pada sisi lain juga menjadikan madrasah semakin terpuruk citranya di mata masyarakat, terutama bila dikaitkan dengan hasil UN. Bagi para pengelola madrasah, kebijakan UN telah memposisikan dan menghadapkan madrasah pada situasi dilematis. Dilema yang dihadapi tersebut lebih disebabkan karena: 1) keterikatan MA dengan konteks historis kelahirannya; dan 2) realitas obyektifnya dengan berbagai kekurangan dan kelemahannya.

Satu hal yang pasti, kebijakan UN telah merubah MA menjadi semakin kehilangan jati diri dan rohnya sebagai madrasah. Indikator tentang hal ini dapat dilihat dari semakin berkurangnya kurikulum/ pengajaran ilmu-ilmu agama Islam, yang berakibat pada minim/rendahnya penguasaan lulusan MA pada bidang tersebut. Atas dasar realitas ini, menurut Drs. Abdullah Zahid, M.Ag. (Kepala MAN 1 Kudus), MA saat ini tidak cocok lagi menyandang predikat sebagai "Madrasah Aliyah" tetapi lebih tepat disebut sebagai "Sekolah Aliyah". ${ }^{18}$

Untuk dapat mencapai standar kelulusan dalam UN, madrasah harus mempersiapkan siswanya dengan cepat, instant dan sangat pragmatis, seperti menambah jam belajar untuk membahas materi $\mathrm{UN}$, menyelenggarakan tryout, mendatangkan guru dari luar sekolah untuk membimbing siswa, dan lain sebagainya. Singkatnya siswa di-drill agar bisa lulus dalam UN tanpa mempertimbangkan kapasitas dan kemampuan siswa.

Secara akademik, hasil drill bukanlah merupakan cermin dari proses pembelajaran yang dilakukan terus menerus dan berkesinambungan yang melibatkan guru, siswa, dan bahkan orang tua siswa. Adanya "intervesi" yang berlebihan terhadap mata pelajaran yang di-UN-kan menyebabkan UN tidak bisa dijadikan tolak ukur evaluasi pembelajaran secara alamiah, karena telah terdistorsi dengan kegiatan-kegiatan pragmatis dan mekanis seperti pembahasan soal-soal yang terDahulu guna mempredisksi

\footnotetext{
${ }^{18}$ Hasil wawancara dengan Drs. Abdullah Zahid, M.Ag. (Kepala MAN 1 Kudus) pada tanggal 23 Mei 2010.
} 
soal yang akan datang, tryout, driil, bimbingan belajar, dan lain sebagainya.

Karena tingginya standar kelulusan dan tingkat kesulitan soal UN pada satu sisi, dan berbagai keterbatasan yang ada pada MA pada sisi yang lain, maka muncullah dampak negatif. Praktik kecurangan, manipulasi dan ketidakjujuran seolah menjadi rahasia umum dalam pelaksanaan UN, baik oleh guru maupun siswa, dengan modus yang sangat beragam. Dalam penelusuran penulis terhadap para guru dan kepala madrasah, itu semua terjadi sebagai bentuk empati sosial (social empahatic) dan rasa khawatir terhadap peserta didiknya dalam upaya untuk memepertahankan "nama baik" madrasah, yang dipicu oleh sebuah kebijakan pemerintah yang "anti realitas", sehingga menimbulkan kegelisahan dan keresahan. Sudah menjadi rahasia umum, madrasah sebagai lembaga pendidikan masih mengalami berbagai keterbatasan untuk berlangsungnya proses pembelajaran berkualitas. Dalam kondisi seperti ini guru, siswa dan pihak-pihak terkait akhirnya "berkompromi" dan "bersatu" untuk melawan kebijakan UN tersebut dalam bentuk tindakan-tindakan yang bertentangan dengan akhlakul karimah yang tidak dibenarkan secara hukum, yang penting mendapat predikat lulus dan sebisa mungkin dengan nilai tinggi. "Jalan pintas" dan praktik-praktik tidak terpuji tersebut dianggap "sah dan pantas" demi untuk sebuah predikat "lulus". Yang lebih menarik, upaya-upaya manipulatif dan kompromistik tersebut semakin kreatif dari tahun ke tahun, yang sesungguhnya adalah sebuah proses menuju ke arah demoralisasi anak bangsa. Ini tentu sangat bertentangan dengan jati diri madrasah sebagai sekolah umum berciri khas Islam.

Secara jujur harus diakuai pula bahwa, pelaksanaan UN memang telah memotivasi siswa, guru maupun madrasah utuk meningkatkan proses pembelajaran, namun hal itu tidak seimbang dengan beban sosial dan politis yang mereka tanggung. Siswa akan malu kalau tidak lulus, guru merasa akan malu juga kalu muridnya tidaklulus, dan secara institusional lembaga juga akan malu dan prestisenya akan turun bila muridnya (banyak yang) tidak lulus. Implikasinya, madrasah akan semakin sulit mendapatkan siswa pada tahun ajaran baru karena dianggap sebagai madrasah yang tidak berkualitas. Itu artinya madrasah akan tidak memiliki masa depan alias mati, terutama untuk 
madrasah swasta karena "nafas kehidupannya" sangat tergantung pada sumbangan pendidikan dari siswa.

Proses pembelajaran yang bertumpu pada pengejaran angka dan standar kelulusan, tidak menempatkan siswa sebagai subyek tetapi hanya menjadi obyek yang harus menguasai berbagai macam materi UN tanpa mempertimbangkan kapasitas siswa, sangatlah tidak manusiawi. Inilah yang oleh Paulo Freire disebut dengan konsep pendidikan banking concept of education. ${ }^{19}$ Praktik pendidikan seperti ini secara sistematik akan membius dan mematikan kreativitas siswa dengan segala potensi yang dimilikinya. Yang terjadi, siswa menjadi gelisah, stress, frustasi, bahkan depresi karena dihinggapi rasa takut dan malu jika gagal UN. Berdasarkan paparan para guru yang penulis wawancarai secara random, tidak sedikit siswa yang sedih dan menangis setelah keluar dari ruang pelaksanaan UN karena tidak yakin atas jawaban yang mereka kerjakan, padahal menurutnya, dalam satu tahun terakhir ini ribuan soal telah dipelajarinya, namun hanya sedikit sekali yang keluar dalam soal UN. Dalam Istilah Pierre Bourdieu, inilah praktik kekerasan simbolik (symbolic violence) ${ }^{20}$ yang amat berbahaya bagi perkembangan psikologis siswa. Dalam istilah Paulo Freire, praktik ini disebut dengan dehumanisasi (dehumanization) di dunia pendidikan yang bertentangan dengan fitrah manusia yang bebas dari kekangan. ${ }^{21}$ Praktek pendidikan yang demikian ini juga akan berdampak secara psikologis dan mengganggu perkembangan mental anak (mental disorder) dalam mengarungi kehidupan selanjutnya. ${ }^{22}$

Ini artinya praktik pendidikan kita telah terjebak pada logika pelatihan yang mekanistik dan praktis, sehingga menyebabkan involusi pendidikan, yakni peningkatan kualitas pendidikan madrasah bahkan sekolah pada umumnya hanya sebatas artifisial saja belum sampai menyentuh bagian substansial. Bahkan demi UN angka telah menjadi "dewa" yang paling ditakuti oleh siswa, guru, orang tua, bahkan madrasah sebagai lembaga. Yang lebih

${ }^{19}$ Paulo Freire. 2000. Pendidikan Kaum Tertindas. (Jakarta: LP3ES), hlm. 55.

${ }^{20}$ Pierre Bourdieu dan Jean Claude Passeron, Reproduction in Education, Society and Culture, (London: Sage Publication, 1990), hlm. 1.

${ }^{21}$ Freire, Pendidikan Kaum Tertindas..., hlm. 19.

${ }^{22}$ Marsana Windhu. Dimensi Kekerasan Tinjauan Teoritis atas Fenomena Kekerasan”. Dalam Franz Magnis Suseno (ed), Melawan Kekerasan Tanpa Kekerasan. (Yogyakarta: Pustaka Pelajar, 2000), hlm.14. 
ironis lagi, ketakutan dan kekhawatiran ini malah justru mendorong praktek-praktek yang tidak jujur di madrasah. Padahal UN sejatinya merupakan instrumen untuk melaksanakan evalusi mengenai proses pembelajaran yang telah dilakukan oleh guru, siswa, dan orang tua.

Berdasarkan identifikasi peneliti terhadap pelaksanaan UN di MA di Kudus, ada tiga komponen dalam MA yang paling terbebani, yaitu:

1. Guru

Guru merupakan variabel penting dan strategis untuk berlangsungnya proses dan hasil pendidikan berkualitas. Bahkan kehadiran guru yang kompeten dan berkualitas akan mampu mensubstitusi kekurangan yang ada pada komponen pendidikan yang lain. Dalam istilah Dedi Supriyadi, kemajuan Prestasi belajar siswa banyak bergantung pada kepiawaian guru dalam membelajarkan siswa, $^{23}$ serta lingkungan pembelajaran yang mendukung proses belajar mengajar.

Dalam konteks pelaksanaan UN di Madrasah, keberadaan guru dianggap sebagai sosok yang paling bertanggungjawab terhadap keberhasilan siswa dalam UN. Untuk mewujudkan harapan tersebut guru-guru pengampu mata pelajaran yang di-UN-kan, dengan dukungan dari kepemimpinan madrasah, menyelenggarakan/menambah jam pelajaran guna membahas soal-soal yang telah diujikan pada tahun sebelumnya.

Proses ini sesungguhnya hanyalah prediksi dengan harapan soal-soal (sebagian) diujikan kembali. Bila ternyata soal-soal yang telah dipelajari tersebut ternyata tidak keluar dalam UN, maka siswa pun akan kecewa, sedih, menangis, bahkan depresi karena tidak mampu mengerjakan soal UN. Fakta inilah yang membuat para guru menjadi gelisah dan khawatir, sehingga mendorong guru untuk melakukan pengulangan-pengulangan materi pelajaran, bahkan melakukan tindakan yang bertentangan dengan nilai-nilai kependidikan dan akhlakul karimah.

Di samping usaha yang bersifat rasional empiris tersebut, hampir di semua madrasah di kudus juga melakukan usaha-

${ }^{23}$ Dedi Supriyadi, Mengangkat Citra Guru dan Martabat Guru. (Yogyakarta: Adicita Karya Nusantara, 2000), hlm. 179. 
usaha yang bersifat spiritual yang dilakukan tidak hanya oleh siswa tetapi juga melibatkan guru dan orang tua siswa dengan mengadakan ritual-ritual keagamaan, seperti istigosah, mujahadah secara periodik menjelang UN, membaca wirid, salat ḍha bersama, ziarah kubur wali, dan melakukan ritual pada tengah malam seperti șalat tahajud, membaca tahlil dan manaqib secara berjama'ah. Bahkan di beberapa madrasah, para guru atas perintah pihak madrasah meminta ijazah/do'a khusus kepada para kiai kharismatik dan habib dengan meminum air yang telah didoakan. Semua tradisi keagamaan tersebut, dalam konteks UN telah mengalami disorientasi tujuan karena dijadikan sarana untuk meminta kelulusan dalam UN. Dalam hal ini guru menjadi aktor dan motivator utama. Sebuah fenomena yang sulit dicari penjelasannya secara ilmiah.

Terkait dengan guru dan mata pelajaran yang di-UN-kan, telah terjadi diskriminasi dan kesenjangan di antara guru-guru di madrasah. Hal ini terjadi karena para guru yang mata pelajarannya di-UN-kan, di samping mendapatkan honorarium yang lebih, prentise mereka juga menjadi naik karena menjadi guru yang penting dan berperan dalam UN. Guru yang tidak mengajarkan mata pelajaran yang di-UN-kan tidak memiliki kesempatan untuk menambah jam pelajaran, sehingga tidak memiliki kesempatan untuk mendapatkan honorarium tambahan. Akibatnya, di madrasah terjadi ketegangan internal yang bersifat laten dan menyebabkan hubungan sosial (social relation) di antara guru menjadi kurang harmonis. Hal ini dapat dilihat dari pergunjingan sosial di atara para guru.

2. Siswa Madrasah

Berbeda dengan di sekolah, dari sudut kurikulum siswa madrasah lebih berat bebannya dibanding dengan siswa sekolah. Seperti telah disinggung di atas, mata pelajaran PAI untuk madrasah dijabarkan dalam lima pelajaran dan masih ditambah dengan kurikulum lokal sesuai visi-misi madrasah (swasta). Oleh karenanya, selain mengikuti ujian nasional, dengan jumlah mata pelajaran yang sama seperti yang diujikan kepada siswa SMA, untuk siswa MA harus mengikuti Ujian Akhir Madrasah Berstandar Nasional (UAMBN), berupa mata pelajaran yang tergabung dalam 
rumpun PAI yang meliputi: Quran-Hadis, Aqidah Akhlak, Fiqh, Sejarah Kebudayaan Islam, Bahasa Arab. Ditambah lagi dengan Ujian Madrasah, yang meliputi mata pelajaran agama Islam yang terangkum dalam Kurikulum Lokal.

Dari sudut pembelajaran, mata pelajaran dan jam belajar yang harus diikuti oleh siswa MA lebih banyak dan panjang dibanding dengan anak SMA. Padahal secara faktual mayoritas siswa madrasah pada umumnya berasal dari kalangan menengah ke bawah yang secara ekonomis akan mengalami beberapa kendala untuk mengikuti pembelajaran tambahan. Secara psikologis penambahan jam pelajaran ini akan mengurangi "ruang dan waktu" untuk menikmati dunia anak/remaja untuk "bermain". Kegiatan belajar yang melampaui kapasitas dan kemampuan siswa ini telah berpengaruh negatif bagi kesehatan dan mental siswa. Tidak jarang mereka menjadi sakit dan terganggu fikirannya.

Kegelisahan dan ketidaktenangan siswa secara mental tersebut (atas arahan dan bimbingan guru) diminimalisir dengan melakukan ritual-ritual keagamaan sesuai dengan tradisi keagamaan yang mereka yakini, seperti istigosah, salat duha, mujahadah, wirid dan lain sebagainya. Fenomena inilah yang nampak di semua MA dalam menghadapi UN, bahkan tidak hanya di madrasah di SMA (negeri dan swasta) juga melakukan hal yang sama, hanya frekuensi dan intensitasnya yang berbeda. Pendeknya, siswa menjadi kelompok yang paling gelisah dibandingkan dengan kelompok guru maupun kelompok orang tua.

\section{Orang Tua Siswa}

Menjelang dan setelah pelaksanaan UN, orang tua murid juga menjadi pihak yang ikut menanggung beban, Baik beban psikis, ekonomis maupun sosial. Berbagai pikiran atau bahkan kegelisahan muncul setelah mereka mendapat penjelasan dari pihak sekolah melalui "sosialisasi UN" yang memang selalu diadakan oleh pihak madrasah. Semua perhatian dan potensi orang tua siswa kemudian juga dicurahkan untuk keberhasilan anak-anak mereka dalam UN. Orang tua yang mampu secara finansial mendorong anaknya untuk mengikuti bimbingan belajar di luar madrasah. Orang tua, siswa dan lembaga bimbingan belajar disibukkan dengan aktivitas pembelajaran yang menekankan pada repetisi soal-soal ujian. Dari sudut 
partisipasi masyarakat/orang tua, ini menjadi sinyal positif bagi keterlibatan dan sinergitas berbagai komponen pendidikan dalam proses pendidikan.

Kekhawatiran dan kegelisahan yang dirasakan oleh orang tua siswa terkadang juga berakibat pada pemaksaanpemanksaan terhadap anak-anak mereka untuk terus belajar demi menghadapi UN. Mereka juga ketakutan bila anaknya tidak lulus di ujian akhir yang mereka ikuti. Untuk melengkapi usaha rasional zahiriyah tersebut para orang tidak jarang juga melakukan usaha spiritual dalam bentuk ritualritual keagamaan tertentu, melaksanakan puasa senin-kamis dan tradisi selamatan. Bahkan pelaksanaan UN telah mampu "mengintegrasikan" upaya-upaya rasional dengan upaya spiritual. Di satu sisi upaya spiritual ini mampu memberikan pencerahan dan peningkatan keimanan seseorang, namun di sisi lain, hal ini juga dapat melemahkan usaha rasional yang dilakukan. Hal ini terjadi karena mereka beranggapan bahwa semua ini sudah ditakdirkan dan diatur oleh Allah swt. Praktik pendidikan dan ritual keagamaan, menurut William A. Smith,seharusnya didasarkan pada kesadaran individualdan panggilan hati nurani seseorang dan bukan didasarkan pada situasi dan kondisi terpaksa, karena kesadaran merupakan proses dialogis dalam diri seseorang dalam upaya memecahkan masalah yang dihadapi secara bersama-sama. ${ }^{24}$

Berbagai fenomena yang muncul sebagai respons atas kebijakan UN yang terwujud dalam sebuah kesadaran, merujuk pada pendapat Mansour Fakih, ${ }^{25}$ dapat dikelompokkan menjadai tiga kesadaran, yaitu: 1) kesadaran magis, yang mengandalkan aspek kekuasaan supranatural/kuasa prima (taqdir) dalam memandang suatu masalah; 2) kesadaran naif, yang memandang aspek manusia yang menjadi penyebab masalah yang muncul dalam masyarakat; dan 3) kesadaran kritis, yang melihat sistem dan struktur sebagai penyebab problematika yang muncul di masyarakat.

Kegelisahan orang tua yang diiringi dengan peningkatan kesadaran meningkatkan partisipasi masyarakat dalam

${ }^{24}$ William A. Smith, Conscientizacao: Tujuan Pendidikan Paulo Freire. (Yogyakarta: Pustaka Pelajar, 2001), hlm.4.

${ }^{25}$ Mansour Fakih, dkk, Pendidikan Populer: Membangun Kesadaran Kritis, (Yogyakarta: Insist, 2001), hlm. 18-23. 
pendidikan merupakan bentuk penguatan sosial untuk transformasi praksis pendidikan. Munculnya aspek religious dalam partisipasi masyarakat mempunyai dampak positif terhadap pengembangan spiritual seseorang, meskipun dalam keadaan terpaksa. Hampir tidak ada jalan keluar dan jawaban pasti untuk menghadapi UN, baik guru, siswa, maupun orang tua, mereka menambatkan segala keinginannya kepada kekuatan supranatural, meski hanya bersifat temporer, karena usaha yang dilakukan telah menguras seluruh potensi yang tidak jarang berimbas pada melemahnya aspek psikologis dan fisik anak.

\section{Probleatika UN di Madrasah}

Di samping tiga kelompok yang paling terbebani dengan pelaksanaan UN, berdasarkan data hasil penelusuran penulis pada 29 MA di Kudus, berikut ini dipaparkan beberapa pengaruh dan dampaknya yang timbul dari pelaksanaan UN di MA. Pengaruh tersebut terutama yang berkaitan dengan praktik dan sistem pembelajaran di MA.

1. Standar Kelulusan.

Standarisasi adalah keniscayaan untuk mencapai dan mengetahui kualitas proses dan hasil pendidikan. Kualitas pendidikan tidak mungkin bisa dicapai tanpa diawali dengan penentuan standar, baik input, proses maupun output-nya. Dalam konteks pelaksanaan UN, penentuan skor standar kelulusan memang menjadi suatu keniscayaan, tapi persoalannya Apakah skor standar kelulusan tersebut sudah didasarkan atas realitas heterogenitas yang melekat pada lembaga pendidikan kita.

Belum lagi persoalan mata pelajaran yang diujikan hanya enam mata pelajaran dari sekian banyak mata pelajaran yang diterima peserta didik dalam proses pendidikan dan pengajaran di MA. Terlebih bila enam mata pelajaran itu kemudian dijadikan penentu, atau setidaknya variabel utama untuk menentukan kelulusan siswa. Di sinilah kemudian muncul pertanyaan, adilkah atau tepatkah standarisasi proses dan hasil pendidikan MA hanya diukur dengan enam mata pelajaran, sementara dalam statusnya sebagai sekolah menengah umum berciri khas agama Islam banyak mata pelajaran tambahan yang diberikan. 
Fakta inilah yang kemudian berdampak negatif pada persepsi dan perilaku siswa dan guru MA. Para siswa menjadi cemas, para guru menjadi kurang percaya diri dan para pengelola manajemen MA menjadi terbayang dengan cerita dan gambaran buruk akan masa depan madrasahnya. Banyak pihak, terutama guru dan siswa menilai meskipun standar yang dipatok masih jauh dari negara-negara maju, tetapi tetap saja mereka khawatir akan kemungkinan tidak lulus dalam UN.

Standar kelulusan yang dipatok dari tahun ke tahun terus naik (untuk tahun 2008 minimal rata-rata 5,25), bagi MA sesungguhnya terlalu tinggi dan berat, terutama untuk sebagian besar MA swasta. Karena terlalu beratnya standar tersebut, maka harapan para pengelola MA dan para guru hanya sebatas yang penting lulus, berapa nilai yang diperoleh menjadi tidak penting. Untuk sekedar menyebut contoh betapa beratnya UN ini bagi MA, seperti yang dikatakan oleh Bapak Ali Muchtadi, S.Ag. (Kepala MA Nurussalam Besito: 17/4/2008), kelulusan dalam UN bagi siswa MA merupakan anugerah yang luar biasa dari Allah) ${ }^{26}$.

Hal itu terjadi karena banyaknya kendala yang dihadapi oleh MA dalam meningkatkan kualitas proses dan hasil pembelajaran, antara lain karena; a) input siswa yang kurang bagus; b) keterbatasan dana bahkan cenderung kurang; c) ada atau bahkan banyaknya guru yang miss-match; d) banyaknya mata pelajaran yang harus diterima oleh siswa. Tidak jauh berbeda dengan para guru, seperti yang dirasakan oleh Khofiyanida Afriani (siswa MA NU Banat kelas XII IPA) ${ }^{27}$, bagi dia dan teman-temannya standar nilai UN yang ditetapkan oleh pemerintah menurutnya terlalu tinggi sehingga menimbulkan kecemasan bagi dia dan teman-teman.

26 Untuk sekedar menyebut contoh betapa beratnya UN bagi MA swasta kecil, pada pelaksanaan UN tahun 2008; di MA Nurussalam dari peserta ujian 86 yang tidak lulus 6 siswa; MA Matholiul Huda dari peserta ujian 19 orang yang tidak lulus 8 siswa; MA Miftahut Tholibin Mejobo angka ketidaklulusan mencapai $60 \%$.

${ }^{27}$ MA NU Banat Kudus adalah termasuk kategori MA swasta terbaik di Kabupaten Kudus, bahkan pada tingkat nasional MA ini pernah mendapat predikat MA harapan terbaik I se-Indonesia. 
2. Terjadinya disorientasi sistem pendidikan dan pembelajaran

Sebelum tahun 2008 mata pelajaran yang diujikan dalam UN hanya tiga mata pelajaran dan mulai tahun 2008 mata pelajaran yang diujikan menjadi enam mata pelajaran, yaitu: a) Jurusan IPA; Matematika, Bahasa Indonesia, Bahasa Inggris, Fisika, Kimia, dan Biologi. b) Jurusan IPS; Matematika, Bahasa Indonesia, Bahasa Inggris Ekonomi, Geografi, dan Sosiologi. c) Jurusan Bahasa; Matematika, Bahasa Indonesia, Bahasa Inggris, Sastra Indonesia, Bahasa Asing lain, dan Antropologi/Sejarah Budaya. Khusus untuk MA ada satu jurusan lagi, yaitu Jurusan Keagamaan (MAKMadrasah Aliyah Keagamaan) mata pelajaran yang diujikan; Matematika, Bahasa Indonesia, Bahasa Inggris, Bahasa Arab, dan Qur'an-Hadis. Penetapan enam mata pelajaran yang diujikan, dari sekian banyak mata pelajaran yang diajarkan di MA inilah yang kemudian berpengaruh besar terhadap kinerja MA dan persepsi siswa terhadap mata pelajaran lain yang tidak diujikan. Pada kenyataannya target dan ukuran kinerja MA hanya fokus pada upaya bagaimana agar persentase angka kelulusan menjadi maksimal atau setidaknya tinggi. Tingkat kelulusan 100\% menjadi ukuran kinerja dan Prestasi suatu MA, sehingga tujuan pendidikan dan pengajaran di MA menjadi tereduksi hanya demi untuk kelulusan UN.

Dengan ukuran seperti ini, maka tidak jarang model pembelajaran dan durasi pembelajaran selalu dihubungkan dengan seberapa besar kontribusinya terhadap kesiapan dan kemampuan siswa untuk mengerjakan soal UN. Yang terjadi makna dan hakikat pendidikan kemudian tereduksi seolah hanya pada kemampuan (kognitif) menjawab soal. Kebermaknaan sebuah proses pendidikan hanyalah sebatas lulus UN dan mendapat ijazah. Internalisasi nilai sebagai tingkatan dan sekuensi penting dalam proses pembelajaran menjadi hilang, karena semua waktu dan usaha difokuskan pada "keterampilan" siswa dalam memahami dan menjawab soal.

Penentuan dan pembatasan mata pelajaran yang akan diujikan dalam UN berdampak pada fokus proses pembelajaran di madrasah yang hanya ditekankan pada penguasaan mata pelajaran tersebut, sedangkan mata pelajaran lain menjadi terabaikan dan seolah menjadi kurang penting. 
Padahal bila melihat tujuan pendidikan di MA mata pelajaran tambahan (PAI) itulah sesungguhnya yang menjadi jati diri dan Karakter esensialnya. Ekses lain adalah terjadinya diskriminasi dan pengabaian terhadap guru dan mata pelajaran lain yang tidak diujikan. Para siswa, guru dan bahkan orang tua lebih memusatkan perhatiannya terhadap mata pelajaran yang akan diujikan dengan berbagai upaya, termasuk berbagai usaha yang bertentangan dengan nilai-nilai fundamental pendidikan.

Melihat gejala tersebut dan dalam rangka untuk menguatkan posisi mata pelajaran PAI dan berbagai mata pelajaran tambahan sesuai visi ke-madrasah-an, beberapa MA swasta yang masuk kategori sedang dan besar membuat kebijakan pengaman. Semua MA swasta di Kudus memberlakukan kebijakan ujian lokal madrasah dengan mengujikan semua mata pelajaran agama Islam yang masuk kategori muatan lokal, dengan mendapatkan ijazah (syahadah) tersendiri.

Bagi MA swasta besar, di samping UN semua siswa diwajibkan lulus ujian madrasah dan kelulusan pada ujian madrasah ini menjadi syarat pengambilan ijazah nasional. Langkah ini, seperti diakui dan dijelaskan oleh para kepala MA cukup efektif untuk meningkatkan motivasi dan minat para siswa untuk tetap serius dan tidak memandang remeh terhadap berbagai mata pelajaran PAI dan mata pelajaran tambahannya.

Hal lain yang muncul dengan adanya kebijakan UN adalah terjadi disorientasi pada arah dan tujuan pembelajaran di MA. Karena sistem dan model UN cenderung hanya mengukur aspek kognitif, maka pembelajaran di kelas cenderung hanya mengolah ranah kognitif, padahal ranah afektif yang sesungguhnya menjadi ranah yang paling penting dalam pembentukan Karakter dan kepribadian peserta didik sebagai muslim yang berakhlak mulia menjadi terabaikan, atau setidaknya kurang mendapatkan porsi yang memadai.

Hal ini dapat dilihat dari berbagai kebijakan sebagian besar MA swasta dalam mempersiapkan siswanya untuk mengikuti UN. Ada beberapa MA yang mengasramakan siswanya selama 1 s/d 2 Minggu untuk "pendalaman" materi UN. Ada MA yang dalam tiga bulan atau satu semester 
menjelang UN tidak mengajarkan mata pelajaran lain kecuali mata pelajaran yang diujikan. Dalam praktiknya dua kegiatan tersebut lebih difokuskan pada latihan mengerjakan atau menjawab contoh-contoh soal UN. Yang lebih memprihatinkan lagi pada setiap akan dilaksanakan UN selalu dibentuk "tim sukses UN", yang dalam banyak hal berkonotasi negatif.

3. Proses pembelajaran yang kurang bermakna

Untuk mempersiapkan para siswanya menghadapi dan mengerjakan soal-soal UN, para guru biasanya menggunakan metode pembelajaran driil, di mana para siswa dilatih untuk mengerjakan sejumlah soal yang diprediksi akan keluar dalam ujian. Melalui metode ini guru mengharapkan para siswa terbiasa menghadapi soal ujian, dan menguasai berbagai teknik dan trik mengerjakan soal yang akan dihadapi. Pembelajaran dengan metode ini sesungguhnya tidak sesuai dengan tujuan pendidikan yang antara lain adalah transfer of values atau internalisasi nilai. Pada ranah kognitif model pembelajaran seperti ini kurang mampu mengembangkan kemampuan berpikir pada tingkatan memecahkan masalah (problem solving), yang sesungguhnya merupakan indikator pencapaian kecerdasan kognitif yang tinggi, sebagaimana diharapkan dalam pencapaian tujuan pembelajaran.

Bila melihat tujuan pendidikan MA, maka tujuan pembelajaran yang lebih penting bahkan menjadi tujuan akhir dari semua proses adalah pembentukan pribadi dan Karakter peserta didik sesuai dengan norma dan ajaran Islam. Tujuan tersebut hanya bisa dicapai manakala sistem dan model pembelajarannya memungkinkan peserta didik untuk bisa memahami dan menghayati. Selanjutnya mengamalkan dalam kehidupan sehari-hari segala apa yang telah mereka ketahui.

Hanya dengan tingkatan seperti ini pembelajaran akan memiliki makna, bila tidak maka pembelajaran hanya sebatas pemberian dan diperolehnya informasi/pengetahuan tanpa memiliki pengaruh dan makna bagi pengembangan diri peserta didik secara menyeluruh dan utuh.

4. Relevan UN dengan kompetensi lulusan MA

Sebagai lembaga pendidikan yang merupakan modernisasi sistem pesantren, MA tidak bisa lepas dari nilai dan 
atribut ke-Islaman. Dalam konteks UN, maka MA menjadi pihak yang merasa diperlakukan tidak fair (unfair treatment), terutama terkait dengan tujuan spesifik dan mata pelajaran yang diujikan.

Dengan hanya enam mata pelajaran yang diujikan, dan semua mata pelajaran Agama Islam baik yang terangkum dalam rumpun PAI maupun mata pelajaran tambahan/pengayaan tidak ada yang diujikan, maka dari sisi tujuan aspek pokok dari tujuan MA menjadi tidak terukur dan terevaluasi. Padahal mata pelajaran PAI ini sesungguhnya merupakan materi inti (core) pembelajaran dalam rangka untuk mencapai tujuan tersebut dan sekaligus menjadi ciri pembeda dengan sekolah umum.

Seperti diakui oleh para pengelola dan guru MA, UN di mata para guru dan siswa dipahami sebagai tujuan akhir dengan kelulusan menjadi indikator keberhasilannya. Guru dianggap sukses dan berkinerja bagus manakala berhasil membawa siswanya menuju kelulusan, dan akan divonis telah gagal menjalankan tugas manakala banyak siswanya yang tidak lulus.

Itulah sebabnya, mayoritas guru merasa berat manakala mendapat tugas/ditawari untuk mengajar di kelas XII atau kelas XI. Mereka merasa lebih nyaman dan tanpa beban jika mengajar di kelas X dan XI. Guru yang mengajar di kelas XII seringkali menghadapi berbagai ketegangan karena beban psikologis, terutama saat-saat mendekati dilaksanakannya UN. Hal ini terjadi pada hampir semua MA swasta, terutama untuk MA swasta kecil yang ada di pinggiran kota. Untuk MA besar/maju, seperti MA negeri dan beberapa MA swasta besar semisal MA NU Banat Kudus, keadaannya mungkin tidak seekstrem itu, karena para siswanya relatif lebih siap dalam menghadapi UN. Di samping para siswanya lebih siap karena input-nya relatif bagus juga didukung oleh kompetensi dan komitmen guru dan berbagai fasilitas yang dimilikinya relatif cukup dan bagus.

Tidak seperti MA swasta kecil pada umumnya, pada MA besar persiapan untuk menghadapi UN tidak ada upaya berlebihan karena pengondisian terhadap siswa dan guru sudah dipersiapkan sejak awal. Seperti dikatakan oleh Bapak Moh. Said (Kepala MA NU Banat Kudus: 14/5/2008), "Saya 
sangat setuju dengan adanya UN seperti yang telah dilaksanakan selama ini yang bertujuan untuk meningkatkan kualitas pendidikan, akan tetapi seharusnya tidak hanya mata pelajaran tertentu saja yang diujikan, tapi juga termasuk mata pelajaran agama (PAI) harus juga diujikan supaya tidak ada diskriminasi terhadap mata pelajaran".

Dengan diujikannya PAI dalam UN, maka perhatian para siswa terhadap pelajaran tersebut menjadi lebih serius dan lebih bermakna, seperti sebelum dilaksanakan UN. Seperti diakui oleh ibu Eti Muznah (Waka Kurikulum MA Nahdhatul Muslimin Undaan Kidul: 27-28/03/2008), sejak dilaksanakannya UN kemampuan pengetahuan agama Islam siswanya menjadi turun drastis. Sebagai contoh beliau merujuk pada kemampuan Bahasa Arab (dan ilmu-ilmu alat lainnya) para siswa menjadi sangat turun sejak diberlakukannya kebijakan UN.

Penyebabnya tiada lain karena konsentrasi para pengelola MA, guru dan siswa hanya tertuju pada mata pelajaran yang diujikan dalam UN. Secara teknis tidak cukup waktu untuk pembelajaran bidang agama Islam tersebut, bahkan hampir semua waktu dan tenaga tercurahkan untuk persiapan pelaksanaan UN. Apa yang dikatakan oleh ibu Eti Muznah ini juga diakui dan dirasakan oleh para guru dan pengelola MA di Kudus pada umumnya.

\section{Penutup}

Kebijakan UN bagi madrasah sesungguhnya membanggakan dan memberi harapan, tetapi sekaligus juga memberatkan. Membanggakan karena dengan UN ini lembaga pendidikan madrasah benar-benar diakui sama dengan sekolah. Memberatkan dan menjadi beban karena mayoritas MA sesungguhnya tidak siap, karena sulitnya soal-soal UN untuk dikerjakan siswa MA. Hal ini terjadi karena proses pembelajaran di sebagian besar MA (terutama swasta) masih menghadapi berbagai kendala dan keterbatasan mulai sarana/prasarana, sumber daya manusia, dan visimisi madrasah.

Di samping harus mengikuti UN, siswa MA juga harus mengikuti UAMBN yang diselenggarakan secara nasional dan sentral dari Kementerian Agama Pusat dengan lima mata pelajaran yang terangkum dalam rumpun PAI. Di samping itu untuk siswa MA 
swasta masih harus mengikuti Ujian Madrasah yang terdiri dari mata pelajaran ilmu-ilmu agama Islam sesuai visi-misi madrasah. Fakta inilah yang menjadikan siswa madrasah menjadi terlalu banyak beban, karena banyaknya mata pelajaran yang harus mereka terima dan semuanya diujikan. Dalam konteks seperti ini maka menjadi tidak adil kiranya bila parameter pengukuran antara sekolah dan madrasah disamakan.

Pelaksanaan UN dengan mengujikan hanya enam mata pelajaran telah menyebabkan diskrimanisai antara mata pelajaran yang diujikan dengan yang tidak diujikan. Mata pelajaran yang diujikan menjadi mata pelajaran yang penting dan yang tidak diujikan menjadi tidak atau kurang penting, demikian halnya dengan gurunya. Diskriminasi tersebut berimbas juga pada ketegangan dan konflik yang bersifat laten antara guru pengampu mata pelajaran yang diujikan dengan yang tidak diujikan.

Karena tingginya standar kelulusan dan sulitnya soal-soal UN maka muncullah kekhawatiran di kalangan guru, siswa, orang tua siswa, dan pihak madrasah tentang kemungkinan ketidak lulusan dalam ujian tersebut. Kekhawatiran ini kemudian mendorong mereka untuk melakukan berbagai upaya mulai dari yang empirik rasional sampai yang bersifat supranatural-ruhaniyah. Bahkan sampai pada usaha-usaha yang bertentangan dengan spirit, nilainilai kependidikan,ahlakul karimah dan melanggar terhadap hukum.

Meskipun tujuan kebijakan UN ini adalah baik dalam rangka untuk mengevaluasi proses dan hasil pendidikan, namun karena berbagai penyimpangan yang terjadi di lapangan kebijakan ini menjadi tidak sesuai dengan harapan dan tujuan. Bahkan kabijakan ini telah menyimpang jauh dari tujuan semula, karena telah menjadi komoditas politik bagi pimpinan madrasah dan pimpinan lokal/daerah. Hal ini terjadi karena hasil UN (prosentase kelulusan) menjadi indikator kinerja guru, kepala sekolah/madrasah, dan pimpinan/birokrat di daerah, sehingga mereka ini berkompromi dan bersepakat dengan berbagai cara untuk "mensukseskan UN" dengan membentuk "tim sukses".

\section{Kepustakaan}


Anderson, J.E, Public policy-making. New York: Holt, Rinehart and Winston, 1979.

Arifin, A., Memahami paradigma baru pendidikan nasional.Jakarta: Ditjen Bagais, 2003.

Azra, Azyumardi, Surau: Pendidikan Islam tradisional dalam transisi dan modernisasi. Jakarta: Logos, 2003.

Burhanudin, J. \& Dina A., Mencetak Muslim Modern: Peta Pendidikan Islam Indonesia. Jakarta: Raja Grafindo Persada. 2006.

Considene, M, Public policy: A critical approach.South Melbourne: Mc Millan Educatio Australia, 1996.

Davis, N.K., Warhurst, J.W.J., \& Waller, Public policy in Australia ( $2^{\text {nd }}$ ed.), NSW Australia: Allen \& Unwin. 1993.

Depertemen Agama RI, Panduan kurikulum 1994 Madrasah. Jakarta: Depag RI, 2004.

Dimyati \& Mudjiono, Belajar dan Pembelajaran, Jakarta: Departemen Pendidikan Nasional berkerja sama dengan Rineka Cipta, 2006.

Dye, T.R., Understanding public policy ( $7^{\text {th }}$ ed.), Englewood Cliffs-New Jersy: Prentice Hall, 1981.

Easton, D., The Political System, New York: Knopf, 1953.

Fernades, H.J.X., Evaluation of Educational Programs, Jakarta: Nasional Educational Planning, Evaluation and Curriculum Development, 1984.

Fullan, M. G., The New Meaning of Educational Change, England: Cassell Educational Limited, 1991.

Harrington, H. J., The improvement process: How America's leading company improve quality, New York: Mc Graw-Hill Book Company, 1987.

Hanuzek, E.A., Education production function, dalam George Psacharopoulos. Econmics of education: Research and studies, London: Oxford; Pergamon Press, 1987.

Hopkins, D., Every School a Great School: Realizing the Potential of System Leadership, New York: Mc Graw Hill-Open University Press, 2006.

Imron, Ali., Kebijakan pendidikan di Indonesia: Proses produk dan masa depannya, Jakarta: Bumi Aksara, 1996. 
MacKinnon, F., The Politics of Education: A Study of Political Administration of the Public Schools, Canada: University of Toronto Press, 1960.

Maksum, Madrasah: Sejarah dan perkembangannya, Jakarta: Logos, 1999.

Mardapi, Djemari, Survey Kegiatan Guru dalam Melakukan Penilaian, Jakarta: Ditjen Dikdasmen Depdikbud, 1999.

Peraturan pemerintahan tentang pelaksanaan undang-undang nomor 2 tahun 1989 tentang sistem pendidikan nasional, Jakarta: Armas Duta Jaya, 1990.

Posavac, E. J. \& Carey, R.G., Program evaluation: Methods and case studies. Englewood Cliffs, New Jersey, Prentice-Hall, 1980.

Prunty, J.J., A critical reformation of educational policy analysis, Victoria: Deakin University Printery, 1984.

Richardson, J. J. (Ed.), Pressure groups. New York: Oxford University, 1993.

Seidman, E., Handbook of Social Intervention, Beverly Hill/London/ New Delhi: Sage Publication, 1983.

Sudjana, Nana, Penilaian Hasil Proses Belajar Mengajar, Bandung: Remaja Rosdakarya, 1989.

Sudjana, N., Penilaian hasil proses belajar mengajar. Bandung: Remaja Rosdakarya, 1995.

Suwito \& Fauzan, (Ed.), Perkembangan Pendidikan Islam di Nusantara: Studi Perkembangan Sejarah dari Abad 20 M, Bandung, Angkasa, 2004.

Taylor, S., Educational Policy and the Politics of Change, London: Routledge, 1997.

Undang-Undang Republik Indonesia Nomor 2 Tahun 1989. Sistem pendidikan nasional, Jakarta: Eko Jaya.

Undang-Undang RI Nomor 20 Tahun2003tentang Sistem pendidikan nasional.

Undang-Undang RI Nomor 2 Tahun 1989 tentang sistem pendidikan nasional.

Undang-Undang RI Nomor 5 Tahun 1974 tentang Pemerintah Daerah.

Undang-Undang Republik Indonesia Nomor. 20 Tahun 2003. Tentang Sistem Pendidikan Nasional 
Nadwa: Jurnal Pendidikan Islam | 363

Zuhairini, Sejarah Pendidikan Islam, Jakarta: Bumi Aksara Bekerja sama dengan Dirjen Bagais Departeme Agama RI, 2004. 